EXPLORING EARTH'S MYSTERIES

...PROTECTING ITS FUTURE

BNL-82418-2009

\title{
Wildland Fire Management Plan
}

\section{for Brookhaven National Laboratory}

\author{
Environmental Protection Division \\ Brookhaven National Laboratory
}

Operated by

Brookhaven Science Associates

Upton, NY 11973-5000 
BNL Wildland Fire Management Plan

\section{DISCLAIMER}

This report was prepared as an account of work sponsored by an agency of the United States Government. Neither the United States Government nor any agency thereof, nor any of their employees, nor any of their contractors, subcontractors or their employees, make any warranty, express or implied, or assumes any legal liability or responsibility for the accuracy,

completeness, or any third party's use or the results of such use of any information, apparatus, product, or process disclosed, or represents that its use would not infringe privately owned rights. Reference herein to any specific commercial product, process, or service by trade name, trademark, manufacturer, or otherwise, does not necessarily constitute or imply its endorsement, recommendation, or favoring by the United States Government or any agency thereof or its contractors or subcontractors. The views and opinions of authors expressed herein do not necessarily reflect those of the United States Government or any agency thereof. 


\section{PREFACE}

This Wildland Fire Management Plan (FMP) for Brookhaven National Lab (BNL) updates the 2003 plan incorporating changes necessary to comply with DOE Order 450.1 and DOE P 450.4, Federal Wildland Fire Management Policy and Program Review; Wildland and Prescribed Fire Management Policy and implementation Procedures Reference Guide. This current plan incorporates changes since the original draft of the FMP that result from new policies on the national level. This update also removes references and dependence on the U.S. Fish \& Wildlife Service and Department of the Interior, fully transitioning Wildland Fire Management responsibilities to BNL.

The Department of Energy policy for managing wildland fires requires that all areas, managed by the DOE and/or its various contractors, that can sustain fire must have a FMP that details fire management guidelines for operational procedures associated with wild fire, operational, and prescribed fires. Fire management plans provide guidance on fire preparedness, fire prevention, wildfire suppression, and the use of controlled, "prescribed" fires and mechanical means to control the amount of available combustible material. Values reflected in the BNL Wildland FMP include protecting life and public safety; Lab properties, structures and improvements; cultural and historical sites; neighboring private and public properties; and endangered, threatened, and species of concern. Other values supported by the plan include the enhancement of fire-dependent ecosystems at BNL. This FMP will be reviewed periodically to ensure the fire program advances and evolves with the missions of the DOE and BNL.

This Fire Management Plan is presented in a format that coverers all aspects specified by DOE guidance documents which are based on the national template for fire management plans adopted under the National Fire Plan. The DOE is one of the signatory agencies on the National Fire Plan.

This FMP is to be used and implemented for the entire BNL site including the Upton Reserve and has been reviewed by, The Nature Conservancy, New York State Department of Environmental Conservation Forest Rangers, and DOE, as well as appropriate BNL emergency services personnel.

The BNL Fire Department is the lead on wildfire suppression. However, the BNL Natural Resource Manager will be assigned to all wildland fires as technical resource advisor. 
Selected Acronyms (See also Appendix A, Definitions and Acronyms)

\begin{tabular}{|c|c|}
\hline Burning Index (BI) & $\begin{array}{l}\text { Estimate of the potential difficulty of containing a fire, related to the flame length at the head of a } \\
\text { fire. BI divided by a factor of } 10 \text { indicates approximate flame length. Used for determining initial } \\
\text { resource needs. }\end{array}$ \\
\hline BNL & Brookhaven National Laboratory \\
\hline DOE & Department of Energy \\
\hline $\begin{array}{l}\text { Emergency Fire Rehabilitation/ } \\
\text { Burned Area Emergency } \\
\text { Rehabilitation (EFR/BAER) }\end{array}$ & $\begin{array}{l}\text { Emergency actions taken during or after wildland fire to stabilize and prevent unacceptable } \\
\text { resource degradation or to minimize threats to life or property resulting from the fire. The scope } \\
\text { of EFR/BAER projects is unplanned and unpredictable, requiring funding on short notice. }\end{array}$ \\
\hline $\begin{array}{l}\text { Energy Release Component } \\
\text { (ERC) }\end{array}$ & $\begin{array}{l}\text { Number related to the available energy (per square foot) in the flaming front at the head of a } \\
\text { fire, from predictions of 1) rate of heat release per unit area during flaming combustion and 2) } \\
\text { duration of flaming. }\end{array}$ \\
\hline Fire Management Plan (FMP) & $\begin{array}{l}\text { Strategic plan that defines a program to manage wildland and prescribed fires and documents } \\
\text { the Fire Management Program in the approved land use plan. Supplemented by operational } \\
\text { procedures: preparedness plans, preplanned dispatch plans, prescribed fire plans, and } \\
\text { prevention plans. }\end{array}$ \\
\hline Fire Management Unit (FMU) & $\begin{array}{l}\text { Area where there are common fire management goals, objectives, and fuels, and where } \\
\text { resource uses have been defined. The size of the unit is not important; however, the FMU } \\
\text { should relate well to the strategies for managing wildland and prescribed fires that are defined } \\
\text { in the FMP. }\end{array}$ \\
\hline FMIS & Fire Management Information System, a computer database. \\
\hline IC & Incident Commander \\
\hline $\begin{array}{l}\text { Incident Command System } \\
\text { (ICS) }\end{array}$ & $\begin{array}{l}\text { Combination of facilities, equipment, personnel, procedures, and communications operating } \\
\text { within a common organizational structure with responsibility for managing assigned resources } \\
\text { to effectively accomplish specific objective(s) pertaining to an incident. }\end{array}$ \\
\hline $\begin{array}{l}\text { Ketch-Byram Drought Index } \\
\text { (KBDI) }\end{array}$ & $\begin{array}{l}\text { Soil/duff drought index that ranges from } 0 \text { (no drought) to } 800 \text { (extreme drought), based on soil } \\
\text { capacity of } 8 \text { inches of water. Index factors are maximum daily temperature and daily and } \\
\text { annual precipitation. }\end{array}$ \\
\hline LCES & $\begin{array}{l}\text { "Look Outs, Communications, Escape Routes and Safety Zones" (a fire safety policy, also the } \\
\text { title of a training course) }\end{array}$ \\
\hline LINWRC & Long Island National Wildlife Refuge Complex \\
\hline NFDRS & $\begin{array}{l}\text { National Fire Danger Rating System - a system that yields a wildfire damage index based on } \\
\text { weather and other factors }\end{array}$ \\
\hline Normal Unit Strength (NUS) & $\begin{array}{l}\text { Amount of noncapitalized fire fighting equipment needed to meet } 70 \text { percent of suppression } \\
\text { needs }\end{array}$ \\
\hline $\begin{array}{l}\text { National Wildfire Coordinating } \\
\text { Group (NWCG) }\end{array}$ & $\begin{array}{l}\text { Interagency operational group to coordinate fire management programs of the participating } \\
\text { agencies. The group provides a platform to agree upon policy, standards of training, equipment, } \\
\text { aircraft, suppression priorities, and other operational considerations. }\end{array}$ \\
\hline NYSDEC & New York State Department of Environmental Conservation \\
\hline Resource Advisor (RA) & $\begin{array}{l}\text { Resource specialist responsible for gathering and analyzing information concerning natural } \\
\text { resources and their uses that may be affected by a fire or by fire suppression activities }\end{array}$ \\
\hline Spread Component (SC) & Rating of the forward rate of spread of a head fire \\
\hline $\begin{array}{l}\text { Wildland Fire Management } \\
\text { Program (WFMP) }\end{array}$ & $\begin{array}{l}\text { Full range of activities and functions needed for planning, preparedness, emergency } \\
\text { suppression, emergency rehabilitation, and prescribed fire operations. Includes managing fuels } \\
\text { to reduce risks to public safety and to restore and sustain ecosystem health. }\end{array}$ \\
\hline $\begin{array}{l}\text { Wildland Fire Situation } \\
\text { Analysis (WFSA) }\end{array}$ & $\begin{array}{l}\text { Decision-making process that evaluates management strategies against selected safety, } \\
\text { environmental, social, economical, political, and resource management objectives as selected } \\
\text { criteria }\end{array}$ \\
\hline
\end{tabular}




\section{CONTENTS}

I INTRODUCTION

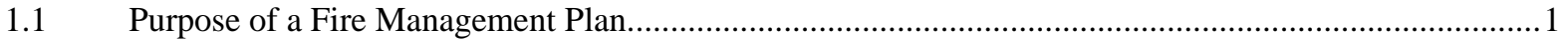

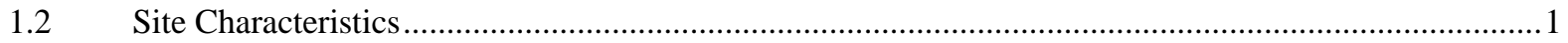

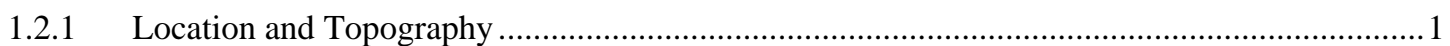

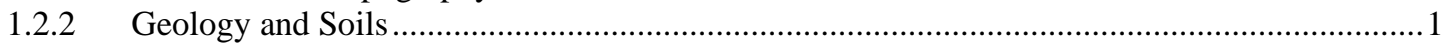

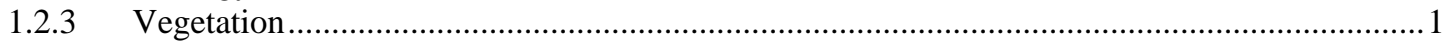

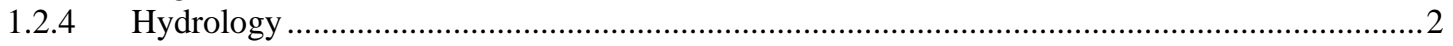

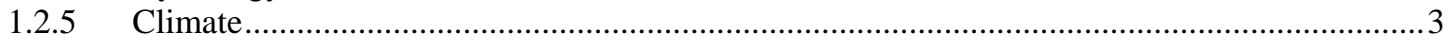

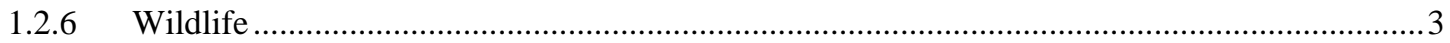

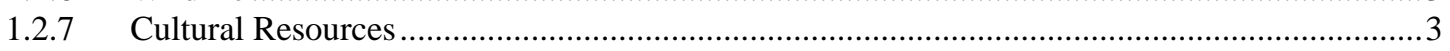

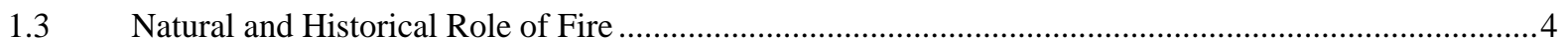

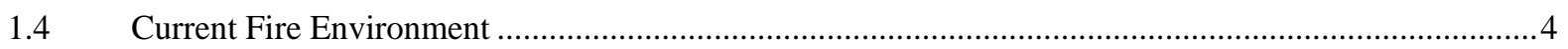

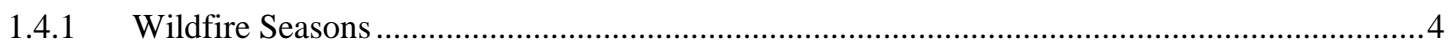

1.4.2 Fuels at BNL and Upton Reserve ………...................................................................

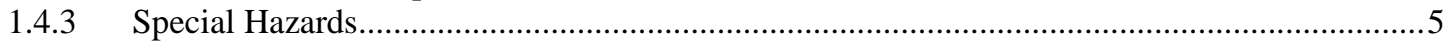

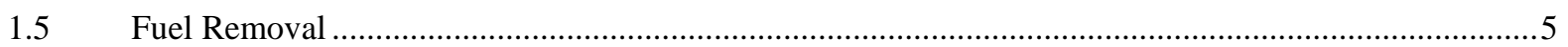

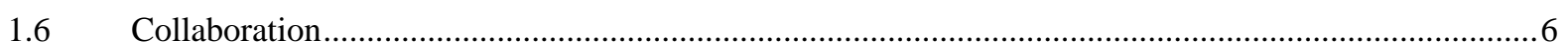

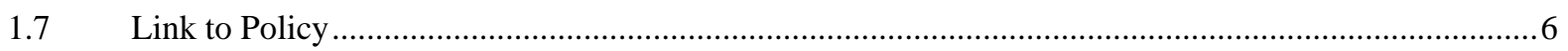

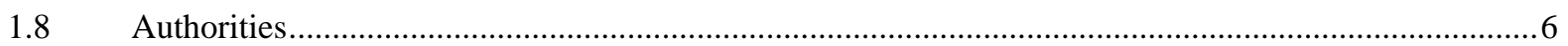

II WILDLAND FIRE MANAGEMENT STRATEGIES

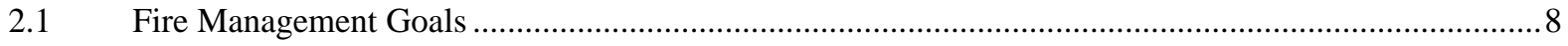

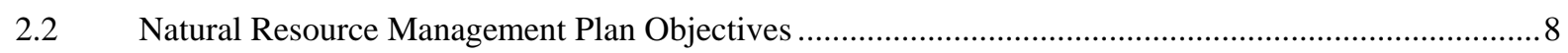

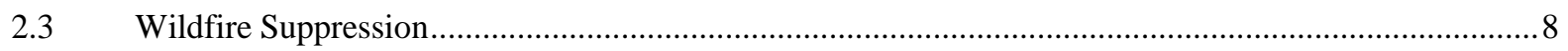

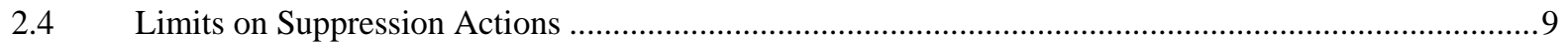

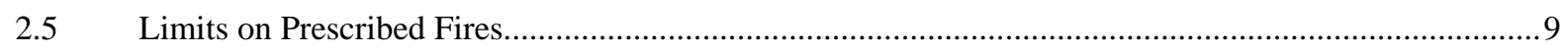

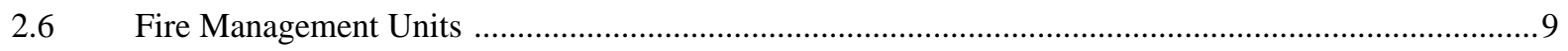

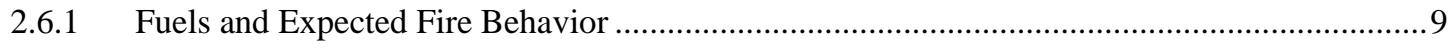

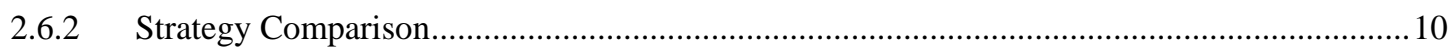

Table 1: Wildland Fire Strategies for Upton Reserve and BNL ........................................................... 10

\section{PLANNING}

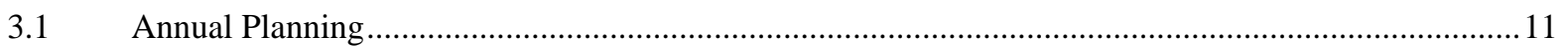

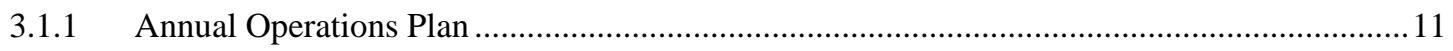

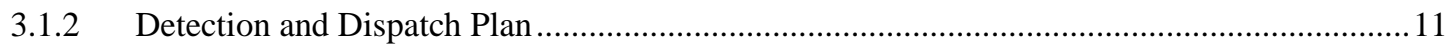

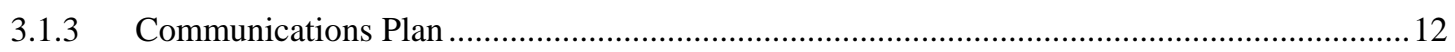

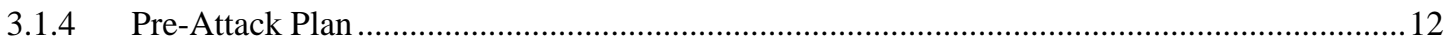

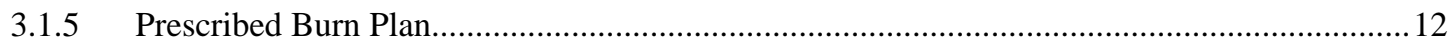

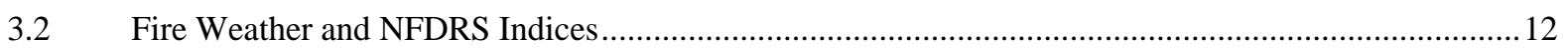

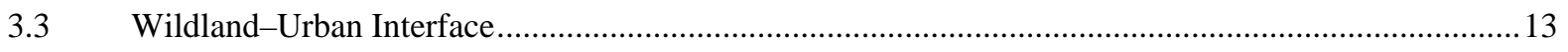

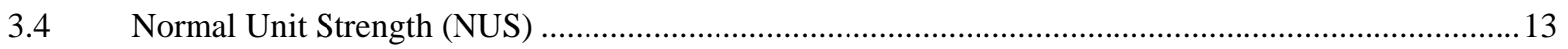

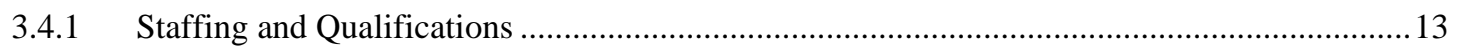

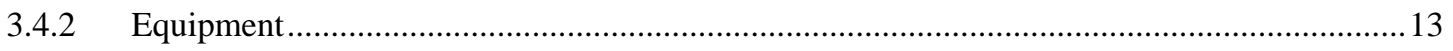

3.4.3 Personal Protective Equipment (PPE) - Prescribed Fire Only.................................................14 


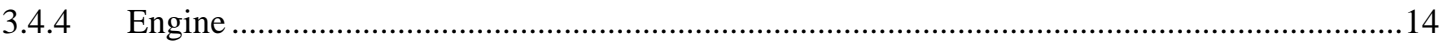

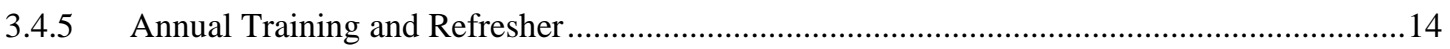

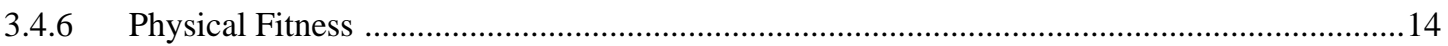

\section{SUPPRESSION OPERATIONS}

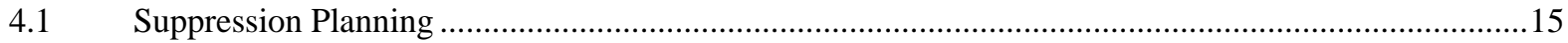

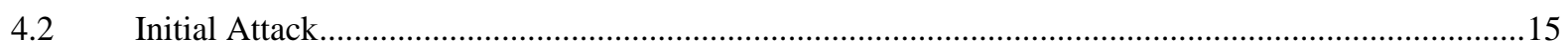

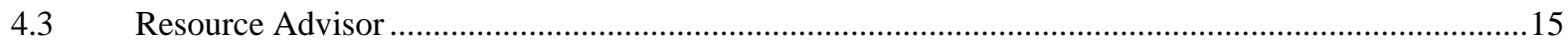

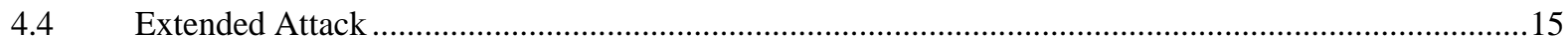

V PRESCRIBED BURNS

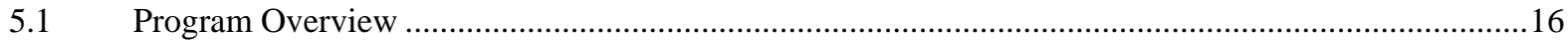

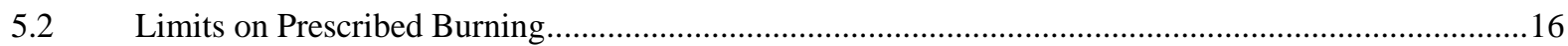

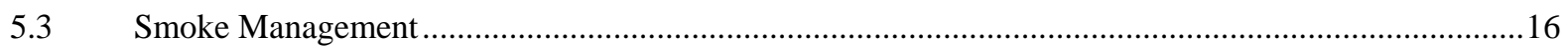

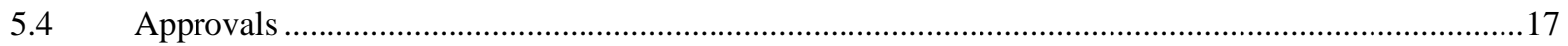

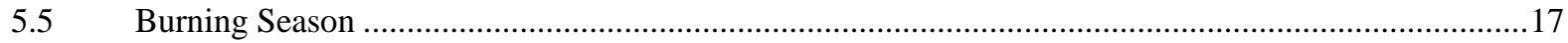

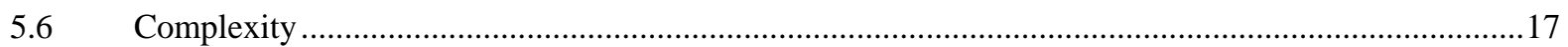

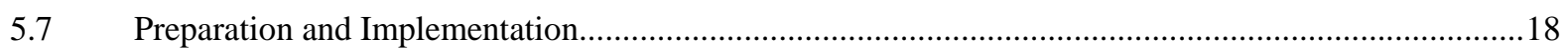

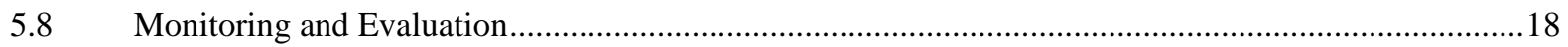

5.9 Guidelines for Prescribed Burns at BNL and Upton Reserve .......................................................18

VI COMMUNITY FACTORS

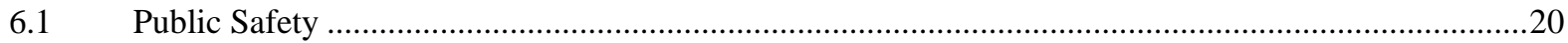

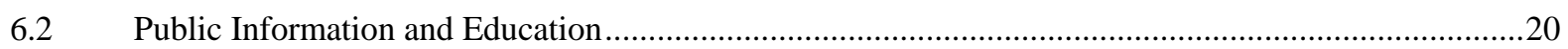

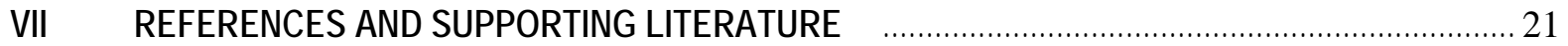

\section{APPENDIXES}

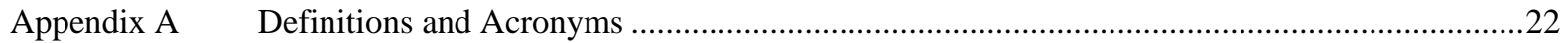

Appendix B Delegation of Authority - Extended Attack _.................................................................27

Appendix C Sample - Prescribed Fire Plan ……..................................................................................29

Appendix D Detection and Dispatch Plan, Staffing Table Prescribed Burn Plan..........................................30

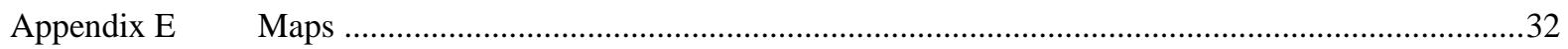

Appendix F $\quad$ BNL Wildland Fire Hazard Severity Analysis.....................................................................34

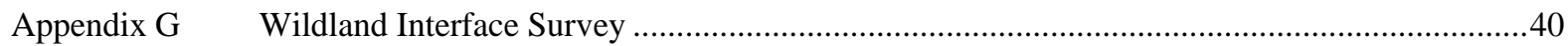




\section{I - Introduction}

\subsection{PURPOSE OF A FIRE MANAGEMENT PLAN}

A Fire Management Plan (FMP) is a document that provides background, guidelines, standards, and recommendations when dealing with natural fires, human-caused accidental fires, operational fires, and prescribed fires. This document provides guidance on the conditions present in the current forest habitat at Brookhaven National Laboratory (BNL), ways to improve upon means for detecting and reacting to fires, and methods for preventing wildland fires from occurring. When implemented, this plan will 1) safeguard the research mission, life, and property by reducing the risk of widespread fire and 2) improve habitat for native flora and fauna.

\subsection{SITE CHARACTERISTICS}

\subsubsection{Location and Topography}

Brookhaven National Laboratory is a 5,265-acre site located in the heart of the Central Pine Barrens on Long Island, New York, approximately 60 miles east of New York City and 60 miles west of Montauk Point. Long Island is approximately 120 miles long, east-west, and 20 miles wide at its widest point. The terrain on Long Island is relatively flat and low except along the north shore. Elevation ranges from sea level to 120 feet, with the highest points occurring on east-west moraines along the north shore and the midsection of Long Island. Topography south and east of the moraines is generally flat with a south-facing slope; this description characterizes the BNL site.

Roughly 1,650 acres of the BNL site are developed, leaving about 3,615 acres as undeveloped woodland. The neighboring communities are predominantly residential developments scattered among wooded acreage. Many of the neighborhoods are virtually hidden by screens of overgrown, vine-covered woodland that lines most of the roads and highways. The majority of the woods is not maintained and contains significant amounts of combustible surface litter.

\subsubsection{Geology and Soils}

Six major stratigraphic units that underlie most of Long Island have been identified in test drilling on site (BNL 1977). From the deepest level to the surface, these units include: the Pre-Cretaceous bedrock, the Raritan formation (with two members), the Magothy formation, the Gardiners clay, and the upper Pleistocene deposits. The upper Pleistocene deposits consist primarily of glacial sand and gravel, plus associated local silt and clay. This unit represents the outwash and moraine deposits of the Wisconsin period. At BNL the thickness of the highly permeable upper Pleistocene deposits varies between 120 and 250 feet (BNL 2008). The sandiest soil is found on the eastern third of the island. On the south shore coastal plain, soils are typically moister. On the north shore the soil is typically finer than elsewhere on the island.

\subsubsection{Vegetation}

The vegetative pattern of Long Island is the result of two main processes, fire, and substrate (soil) composition. When explorers and colonists arrived on Long Island during the sixteenth and seventeenth centuries, the vegetative patterns were dominated by pitch pine forest types and warm season grasslands (Villani 1997). Covering most of the central portion of what is now Nassau County at the west end of the island, the first major vegetative type was the Hempstead Plains-a large and unique grassland dominated by little bluestem, big bluestem, and switch grass. Bordering the Hempstead Plains to the east and extending to present-day western Suffolk County was the oak-brush plains. This area was dominated by a shrubby growth of oak; particularly scrub oak, mixed with other oak species and pitch pine. The next major vegetative group extending from the oak-brush plains eastward to the end of the island was a mix of pitch pine, pine-oak, and oak-pine forests. In the central portion of this region (now the Eastport and Westhampton areas) are the dwarf pine plains, 
dominated by pitch pine less than 10 feet high, scrub oak, and heath vegetation. On the south shore's coastal plain, pine barrens vegetation also existed. Only on the north shore of Long Island were there hardwood trees of any size. There, the vegetation typically consisted of oak forest without the pitch pine component. Except for the Hempstead Plains, which have been greatly reduced by development, most of the original Long Island ecosystems still exist in varying degrees. A large portion of the eastern half of the island is protected habitat within the Central Pine Barrens.

Pine Barrens Ecology. The pine barrens on Long Island represent one of only three known pine barrens ecosystems in the world. Pine barrens have evolved over hundreds to thousands of years in the presence of frequent fires. As a result, plant and animal species of the pine barrens have become adapted to conditions created by periodic fires. The predominant tree in the Long Island pine barrens is the pitch pine (Pinus rigida). Pitch pine seeds germinate and grow best on mineral soil in full sunlight, conditions created when fire burns off surface litter and competing vegetation. The other dominant trees in pine barrens are oaks (Quercus spp.).

How could a forest that requires fire for its survival have developed? Pine barrens are found on quickdraining soils that typically are 80 to 96 percent sand, with low nutrients and high acidity. To help retain moisture, many of the plants in the pine barrens produce waxes, resins, or volatile compounds in their leaves. These substances happen to be highly flammable. Additional plant characteristics that favor fire include decay-resistant litter of low water-absorbing capacity that accumulates on the soil surface, and abundant dead branches and twigs. Pitch pines are able to survive most fires due to thick, insulating bark and to their unusual ability to rapidly sprout from buds in the trunk and root collar. Shrubs and herbs in the pine barrens also rapidly sprout from underground roots and rhizomes.

Some ecologists suggest that pine barrens species alter their environment to favor their own perpetuation. The presence of fire-tolerant species with their volatile foliage supports the formation of fire. Fire consumes material that would otherwise decompose and enrich the soil and make it appropriate for less fire-tolerant vegetation. By reducing nutrient levels, fire favors species that tolerate fire and poor soil, and the presence of these same species favors recurring fire. This feedback loop may be destabilized 1) when fires are suppressed or prevented, 2) when nutrients are added to the soil, or 3) by prolonged wet weather. With prolonged fire exclusion (through active wildfire suppression and fire prevention efforts), plant succession ultimately could result in the replacement of pine barrens by oak forests.

Unique Role. What would be lost if pine barrens were converted to oak forests through fire exclusion? We would lose an endangered ecosystem that is an integral part of the natural environment of Long Island and one of only three pine barrens ecosystems in the world. We would lose many of the rare species of plants and animals found in the pine barrens. We would lose a landscape element that has historically contributed to the scenic, cultural, and environmental diversity of Long Island. In sum, we would lose biological, environmental, and scenic diversity.

\subsubsection{Hydrology}

Brookhaven National Laboratory is situated on the western edge of the relatively undeveloped Peconic River watershed (BNL 2008). The Peconic River, which crosses the site from approximately its northwest to southeast corners, is characterized by a low-gradient streambed and slow flow. The entire Peconic drainage area is considered a Class 1 wetland. Depending on the position of the water table with respect to the riverbed, this shallow river may either receive water from or recharge to the aquifer system underlying Long Island (BNL 2008). During periods of drought the river is generally recharging to groundwater, while during periods of normal to above-normal precipitation the aquifer is supplying water to the river. In general, little direct runoff from precipitation feeds surface streams on Long Island; about half of the annual precipitation is lost to evapotranspiration and most of the remainder passes readily through the highly permeable glacial sand and gravel to recharge the groundwater. 
According to the 2007 Site Environmental Report, BNL draws approximately 2.13 million gallons of groundwater each day to meet its potable water and heating and cooling needs. About 74 percent of this water is returned to the aquifer via on-site recharge basins, and 19 percent is discharged into the Peconic River. The remaining water is either consumed or lost through evaporation or sewer line leaks. Remediation wells are the source of an additional 2.7 million gallons per day of groundwater that is returned to the aquifer using recharge basins (BNL 2008).

In addition to numerous small pocket wetlands that hold water on a seasonal basis, six major regulated wetlands (including the Peconic River drainage area) are also located on site (BNL 2008). The distribution of wet and dry areas on site is well correlated with differences in topography and depth to the water table.

\subsubsection{Climate}

The climate of Long Island is greatly influenced by the Atlantic Ocean and is categorized as humid continental. The climate is dominated by continental influences but the proximity of the ocean produces a significant maritime influence. Temperatures are highest in July and August and coldest in January and February. Winds occur from all directions, although winds with a westerly component are most common. A sea breeze is a common local occurrence at BNL. The hurricane season and tropical storm season is from August through early October. The average rainfall total for BNL is about 45 inches annually. According to the 2007 Site Environmental Report (BNL 2008), there have been four times in the past 50 years when annual rainfall has been approximately 10 inches under this average (1965, 1980,1985, and 2004).

\subsubsection{Wildlife}

Past and ongoing biological inventories of the BNL property have documented numerous wildlife species that permanently reside on or migrate through the site on a seasonal basis (BNL 2008). These include 85 species of nesting birds (as well as an additional 130 species that are not known to nest on site but have been observed there), 15 mammal species, 9 amphibian species, 10 reptile species, and 9 species of fish. The relatively high number of bird species that are documented for BNL can be attributed to the site's location within the Atlantic flyway and to the scrub/shrub habitats present on site that provide food and shelter to migrating songbirds.

Resident species of particular concern are the populations of the NYS endangered eastern tiger salamander (Ambystoma tigrinum tigrinum) and NYS threatened species the banded sunfish (Eanneacanthus obesus), the swamp darter (Etheostoma fusiforme), and frosted elfin (Calophrys iris) (BNL 2002). There are 15 confirmed breeding sites on BNL property for the eastern tiger salamander in vernal ponds and recharge basins. The banded sunfish is known only from the Peconic River system and has been observed in the section of the river on site, while the swamp darter is known to be present at only one location on site. The frosted elfin has not been documented on site within the recent past but known habitat for this small butterfly remains at the original locations of historic occurrence. Other NYS species that are either found at BNL or are expected to be present include the endangerd persius duskywing butterfly (Erynnis persius persius), threatened pine barrens bluet (Enallagma recurvatum), and threatened northern harrier (Circus cyaneus) (BNL 2008).

\subsubsection{Cultural Resources}

BNL is subject to provisions of both the National Historic Preservation Act and the Archeological

Resource Protection Act, which require it to "identify, evaluate and protect historical and archeological sites eligible for listing in the National Register of Historic Places” (BNL 2008). Thus far, three structural complexes or features on site have been identified as eligible for inclusion on the register: the Brookhaven Graphite Research Reactor Complex, the High Flux Beam Reactor Complex, and the networks of trench warfare training trenches that remain from the days of the U.S. Army's Camp Upton in World War I. BNL has developed a formal Cultural Resource Management 
Plan That provides guidance for the identification and management of cultural resources including thouse mentioned above as well as two archeological sites identified during the plan development.

Of course, BNL's scientific research mission is the primary, albeit intangible, cultural resource on site-it would be directly threatened by widespread wildfire and the resultant damage to invaluable facilities.

\subsection{NATURAL AND HISTORICAL ROLE OF FIRE}

Wildfire has been an important process in shaping the terrestrial vegetative pattern of North America (Pyne 1997a, b). Many habitats in the Northeast belong to fire groupings and regimes that are characterized by "long" (100- to 300-year) return intervals or "very long" (more than 300-year) return intervals between fires (Barbour and Billings 1988, Heinselman 1981). In the pitch pine barrens of Long Island, both light and severe surface fires as well as stand-replacement crown fires occur at "short" (25- to 50-year) return intervals (Olsvig et al. 1979). In fact, both surface and standreplacement fires may have occurred every 10 to 40 years. Most of the fires on Long Island are believed to have been the result of Native American activities relating to land management and hunting. Lightning-sparked fires are less frequent than in the western United States, because lightning strikes on Long Island usually occur in the rainy season and the combustible materials are usually also somewhat damp, given the normal annual rainfall. Historically, the warm season grasslands (Hempstead Plains), oak-brush plains, and dwarf pine plains had the highest fire frequencies. Fires also occurred frequently, but not to the same extent as the preceding group, in pitch pine, pine-oak, and oak-pine stands. Fires also were common in the pine barrens vegetation along the south shore. Fires were less common in the forests north of the moraines, on the island's north shore.

\subsection{CURRENT FIRE ENVIRONMENT}

Because of aggressive fire suppression over the past 75 years, a large amount of natural fire fuel (leaf litter and branches) has built up in the forest understory at BNL and surrounding areas. This could easily be ignited and cause great damage to the forest and the surrounding structures at BNL.

\subsubsection{Wildfire Seasons}

On Long Island, wildfires typically occur during two main seasons. Most wildfires occur in spring, from early March through early June (generally before leaf out is complete). Fires in these months typically burn fuels on the surface forest and understory but typically do not burn the crowns of trees. The second fire season occurs during the late summer (late July) through early autumn (early October), particularly during drought years. Wildfires during this period are not as frequent but have the capacity to become larger.

\subsubsection{Fuels at BNL}

Most of the vegetation at BNL consists of pine-oak or oak-pine forest with a dense understory of flammable scrub oak, blueberry, and huckleberry. Leaf litter provides a "flash" fuel: the dead twigs and branches in the shrub layer ignite easily. Except during spring, leaves of most shrub species will readily burn. The leaves and stems of the shrubs sustain fire and can carry heat and flames upward to the canopy. In most stands, the dense shrub layer provides a continuous horizontal and vertical source of fuel. Flames three times the height of the shrub layer are common under wildfire conditions. Crowning (burning in the tops of trees) and spotting (isolated patches of fire spread by wind carrying brands) are a danger when pitch pines are present, because volatile resins in the needles support intense fires during the growing season. High accumulations of standing dead shrubs aggravate this situation. Under wildfire conditions, the rate of spread, flame height, and intensity under wildfire may exceed the capability of fire fighters to carry out a direct attack. 


\subsubsection{Special Hazards}

With only about 30 percent of the Laboratory area developed, BNL research facilities can be seen as an island in a forest of fire fuel. Extreme wildfires equivalent to the Rocky Point and Sunrise fires of August/September 1995, which burned approximately 7,000 acres cumulatively, would seriously jeopardize employee safety and lab facilities. According to a nationally recognized model for rating wildland fire risk, the hazard severity at BNL is "moderate.” Adequate precautions are in place to minimize the hazards for most major facilities at BNL. Several necessary physical improvements were identified in two analyses performed in 2001 and 2002, outlined in the BNL Wildland Fire Assessment (Appendix G) and Wildland Interface Survey (Appendix H). This FMP is, in part, a response to that analysis.

An initial issue of concern was the possibility for a wildfire to release radioactive contaminants into the air, via smoke. Although some areas at BNL contain small amounts of radioactive contamination in the soil, the majority of these materials are found within the developed area of the Laboratory, which would not be subject to catastrophic wildland fire. Naturally occurring radioactive materials are present within the soils and vegetation on Long Island, but to become airborne those radionuclides would have to first be present in plant material that burns. Surveys carried out by both the Environmental Restoration Division and Environmental Protection Division at BNL indicate that almost non-detectable amounts of radionuclides are taken up by plants. If such plants were to burn, particles containing trace amounts of radioactive material would be diluted when the column of smoke mixed with air. The hazards just from noncontaminated smoke would outweigh any possible additional dangers from smoke containing traces of radioactive material.

On the BNL site, only one area historically contained levels of radioactive contamination within the soils significant enough to require management actions. In the event of a wildland fire this area would be managed administratively to protect equipment from contamination. Analysis of a release situation within a fire scenario indicates little or no health risks associated with this incidence and this scenario has greatly improved due to environmental clean up and restoration of the area.

Radionuclide sources for research have numerous layers of protection. Sources are sealed and within shielding. There are security alarms and physical barriers, administrative controls and consequence assessment studies. Buildings that contain sources are typically constructed of noncombustible materials, are equipped with fire detection systems, and/or are equipped with fire suppression systems. These measures severely limit the frequency of events and the potential to release radioactive material. BNL also has a Fire Department that is staffed 24 hours a day, seven days a week, with arrival times of less than 5 minutes after an alarm, further limiting fires to small sizes.

\subsection{FUEL REMOVAL}

Paradoxically, a management policy that prevents and suppresses wildland fires could result in catastrophic wildfires that destroy property, threaten public safety, and damage pine barrens species beyond their normal ability to recover. Such wildfires could occur if there were an unusually large amount of fuel accumulation and a weather pattern involving prolonged drought. If sustained high winds, with low humidity (much as in 1995), were also to occur in this scenario, the outlook could be grim.

To counter this danger, it is necessary to remove the potential fuels. Removal can be done "mechanically" using heavy equipment and/or skilled labor using hand tools. Fuel removal also can be accomplished by prescribed burning under safe conditions, including those that minimize harm to animals. In areas where ecological or safety issues are critical, burn areas are carefully selected. The goal of mechanical fuel reduction is the same as burning, and the results are often similar, but the difference is the cost. Mechanical fuel reduction is often more expensive than prescribed burning. 
However, when the risks of a burning operation are too high, mechanical fuel reduction may be more appropriate.

\subsection{COLLABORATION}

BNL routinely works in collaboration with several other organizations involved in wildland fire management including the New York State Department of Environmental Conservation, the U.S. Fish \& Wildlife Service, The Nature Conservancy, and local volunteer fire departments. BNL annually hosts the New York Wildland Fire and Incident Command Academy and works collaboratively in development of curriculum and instruction at the Academy.

\section{$1.7 \quad$ LINK TO POLICY}

This fire management plan is a detailed program of action to carry out fire management policies. This plan fulfills the requirements of DOE Order 450.1 (DOE 2003) to protect site resources from wildland and operational fires. Fire management policies discussed in this document are intended to agree with and link to overall policies of the National Fire Management Plan.

\section{$1.8 \quad$ AUTHORITIES}

Authority and guidance for implementing this plan are found in the following documents:

- DOE Order 450.1: Environmental Protection Program. Mandates the development of a fire management plan.

- Protection Act of September 20, 1922 (42 Stat. 857; 16 U.S.C.594): Authorizes the Secretary of the Interior to protect from fire, lands under the jurisdiction of the Department directly or in cooperation with other federal agencies, states, or owners of timber.

- Economy Act of June 30, 1932: Authorizes contracts for services with other federal agencies.

- Reciprocal Fire Protection Act of May 27, 1955 (69 Stat. 66, 67; 42 U.S.C. 1856, 1856 a and b): Authorizes reciprocal fire protection agreements with any fire organization for mutual aid with or without reimbursement and allows for emergency assistance in the vicinity of agency lands in suppressing fires when no agreement exists.

- Disaster Relief Act of May 22, 1974 (88 Stat. 143; 42 U.S.C. 5121): Authorizes federal agencies to assist state and local governments during emergency or major disaster by direction of the President.

- Wilderness Act of 1964: Provides guidelines for minimum tool use in administering wilderness areas.

- Federal Fire Prevention and Control Act of October 29, 1974 (88 Stat. 1535; 15 U.S.C.2201): Provides for reimbursement to state or local fire services for costs of firefighting on federal property.

- Wildfire Suppression Assistance Act of 1989. (Pub. L 100-428, as amended by Pub. L 101- 11, April 7, 1989).

- National Environmental Policy Act of 1969: Regulations implementing the National Environmental Policy Act (NEPA) encourages the combination of environmental comments with other agency documents to reduce duplication and paperwork (40 CFR 1500.4(o) and 1506.4).

- Clean Air Act (42 United States Code (USO) 7401 et seq.): Requires states to attain and maintain the national ambient air quality standards adopted to protect health and welfare. This encourages states to implement smoke management programs to mitigate the public health and welfare impacts of wildland and prescribed fires managed for resource benefit. 
- Endangered Species Act of 1973.

- Federal Fire Management policy of 1995 (2001 Review and Update): Establishes a national policy for all agencies involved with wildland fire. 


\section{II- Wildland Fire Management Strategies}

The term wildland fire includes natural or "wild" fires, and fires caused by man, both accidental and prescribed fires (intentionally set for fuel management purposes) that occur in undeveloped land or at the interface between undeveloped and developed land (the wildland-urban interface). Wildland fire management includes the suppression of wild fires in the wildland, and the use of prescribed fires to meet wildland management goals.

\section{$2.1 \quad$ FIRE MANAGEMENT GOALS}

The goals of the fire management program are listed below.

- Ensure protection of life

- Ensure protection of property and research programs

- Improve overall health of BNL forests and ecosystems

\subsection{NATURAL RESOURCE MANAGEMENT PLAN OBJECTIVES}

BNL's Natural Resource Management Plan (NRMP) forms part of the foundation of the FMP. Listed below are some of the objectives of the NRMP. The NRMP was developed in parallel with the FMP and both are updated periodically to adjust for changing goals and objectives.

- Maintain available habitat to perpetuate the migratory bird resource and biological diversity

- Maximize use of BNL land managed for restoration of threatened and endangered species

- Minimize loss of habitat and property caused by wildfire

- Support research in the Upton Reserve

- Reduce fuel loading to lessen incidence of catastrophic fire

- Manage BNL forest resources for long-term ecosystem sustainability

\subsection{WILDFIRE SUPPRESSION}

The suppression strategy for wildfires occurring at BNL and the Upton Reserve will be based on the appropriate management response. Minimum Impact Suppression Techniques (MIST) will be used whenever possible. Natural and human-made barriers will be used to the fullest extent possible in suppressing wildfires. However, fires occurring in the wildland-urban interface with high potential for causing damage to property or threatening human life and health will be aggressively suppressed using the most appropriate means. Suppression strategies included the following measures:

- When possible, suppress wildfires through indirect attack by use of fire/fuel breaks.

- Limit wildfires to the smallest acreage loss possible.

- Minimize ecological damage by limiting use of vehicles in forest.

- Conduct prescribed fires to improve or maintain wildlife habitats and remove fire fuel; specifically, to maintain forest openings, grasslands, and pine barrens vegetation and to reduce fuel loads and remove exotic/invasive nuisance vegetation, and to manage for insect pests appropriately. 
- Monitor fire weather conditions daily and base management decisions on current and predicted fire conditions. (For example, let small fires burn to a fire/fuel break.)

\section{$2.4 \quad$ LIMITS ON SUPPRESSION ACTIONS}

Wildfire suppression activities are limited by the following considerations:

- Accessibility to certain areas by vehicles*

- Equipment may limit response or suppression options and timing.*

- No impact to water resources may occur, such as significant water drawdown of ponds.

- Aerial and foam retardants will not be used within 300 feet of open water, waterways, and wetland areas.

- Plow lines must be rehabilitated to avoid unnecessary erosion and habitat fragmentation.

"Note: These are not major concerns for BNL.

\section{$2.5 \quad$ LIMITS ON PRESCRIBED FIRES}

Prescribed fire activities are limited by the following considerations:

- All prescribed fire operations will be conducted in accordance with federal and state laws and regulations.

- Prescribed fire will not be used in areas with known environmental contamination (Appendix G).

- Prescribed fire will not occur in a fire management unit until soil and vegetation monitoring have occurred.

- Prescribed fire will not be conducted without full concurrence of BSA and DOE management.

\subsection{FIRE MANAGEMENT UNITS}

BNL will be managed as two Fire Management Units (FMUs) with specific fire management goals and objectives. These two FMUs will be the Upton Reserve (FMU 1) and the rest of BNL (FMU 2). Each unit may be divided into smaller sub-units to facilitate development of prescribed or mechanical treatment management plans. The two units have similar fuels and expected fire behavior, but have different operational objectives.

\subsubsection{Fuels and Expected Fire Behavior}

A quantitative basis for rating fire danger and predicting fire behavior is based on mathematical models that require descriptions of fuel properties as inputs. The collections of fuel properties have become known as fuel models and can be organized into four groups: grass, shrub, timber, and slash. A National Wildfire Coordinating Group (NWCG) document, Aids to Determining Fuel Models for Estimating Fire Behavior (Anderson, H.A. 1982), is a guide to help resource managers define the fuel model they are working with in their area. Two types of surface fuel predominate at BNL:

- Hardwood litter. The expected fire behavior is that fires run through hardwood surface litter faster than through fuels in wet or swamp areas and have longer flame height. Autumn fires in hardwoods are predictable, but high winds cause higher rates of spread in the autumn because of spotting caused by rolling and blowing leaves. Concentrations of dead woody material that have fallen to the ground can contribute to "torching out" of trees (combustion of a single tree), spotting, and crowning. 
- Shrubs. Fire is generally carried in the surface fuels that are made up of litter cast by the shrubs and the grasses or forbs in the understory. The fires are generally not intense because surface fuel loads are light, the shrubs are young with little dead material, and the foliage contains little volatile materials.

\subsubsection{Strategy Comparison}

The strategies for handling wildland fires in the two FMUs are similar. The following table outlines the options and goals for each.

Table 1. Wildland Fire Strategies for Upton Reserve and BNL

\begin{tabular}{|c|c|c|}
\hline & Upton Reserve & BNL \\
\hline $\begin{array}{l}\text { Management } \\
\text { Options }\end{array}$ & $\begin{array}{l}\text { - } \text { Fire Suppression } \\
\text { - } \quad \text { Prescribed Fire }\end{array}$ & $\begin{array}{l}\text { - } \text { Fire Suppression } \\
\text { - } \quad \text { Conditional Prescribed Burning }\end{array}$ \\
\hline $\begin{array}{l}\text { Resource } \\
\text { Management } \\
\text { Goals }\end{array}$ & $\begin{array}{l}\text { - Protect life and natural resources or property } \\
\text { (wildland-urban interface) from the effects of } \\
\text { catastrophic wildfire. } \\
\text { - Limit smoke impacts to the surrounding communities } \\
\text { and BNL facilities }\end{array}$ & $\begin{array}{l}\text { - Protect life and natural resources/property (wildland- } \\
\text { urban interface) from the effects of catastrophic } \\
\text { wildfire. } \\
\text { - Limit smoke impacts to the surrounding communities } \\
\text { and BNL facilities. }\end{array}$ \\
\hline $\begin{array}{l}\text { Unit } \\
\text { Objectives }\end{array}$ & $\begin{array}{l}\text { - Suppress wildfires using the appropriate } \\
\text { management response commensurate with firefighter } \\
\text { and public safety and values of the natural resources } \\
\text { and properties at risk. } \\
\text { - Use minimum-impact fire suppression tactics (MIST) } \\
\text { as appropriate. } \\
\text { - Use prescribed fire and mechanical treatments to } \\
\text { reduce hazardous fuel loadings where appropriate. } \\
\text { - Use prescribed fire with other methods to maintain } \\
\text { habitat and control the encroachment of invasive } \\
\text { species. }\end{array}$ & $\begin{array}{l}\text { - Suppress wildfires using the appropriate } \\
\text { management response commensurate with } \\
\text { firefighter and public safety and values of the natural } \\
\text { resources and properties at risk. } \\
\text { - Use minimum-impact fire suppression tactics (MIST) } \\
\text { as appropriate. } \\
\text { - Employ aggressive mop-up tactics to prevent } \\
\text { smoldering fires and minimize smoke production and } \\
\text { impacts. } \\
\text { - Use prescribed fire and mechanical treatments to } \\
\text { reduce hazardous fuel loadings where/when } \\
\text { appropriate. } \\
\text { - Use prescribed fire with other methods to maintain } \\
\text { habitat and control encroachment of invasive species } \\
\text { that may affect the Reserve. }\end{array}$ \\
\hline Unit Strategies & $\begin{array}{l}\text { - Identify areas of concern and develop response } \\
\text { plans and tactics to expedite the initial attack and full } \\
\text { suppression of the fire. } \\
\text { - When possible, use natural barriers other than line } \\
\text { construction as holding lines during suppression } \\
\text { operations. } \\
\text { - Use minimum-impact suppression techniques (MIST) } \\
\text { when possible. } \\
\text { - Develop a prescribed fire plan annually to identify } \\
\text { burn units. } \\
\text { - Use prescribed fire as a management tool for } \\
\text { reducing hazard fuels and meeting resource } \\
\text { management objectives. } \\
\text { - Use federal assets when fire goes to an extended } \\
\text { attack situation. }\end{array}$ & $\begin{array}{l}\text { - Identify areas of concern and develop response } \\
\text { plans and tactics to expedite the initial attack and full } \\
\text { suppression of the fire. } \\
\text { - When possible, use natural barriers other than line } \\
\text { construction as holding lines during suppression } \\
\text { operations. } \\
\text { - Develop a prescribed fire plan as necessary for } \\
\text { identified fuel and ecosystem management } \\
\text { objectives } \\
\text { - Use federal assets when fire goes to an extended } \\
\text { attack situation. }\end{array}$ \\
\hline $\begin{array}{l}\text { Limits on } \\
\text { Actions }\end{array}$ & $\begin{array}{l}\text { - Mechanical equipment should be used only with } \\
\text { recommendation of the BNL Natural Resource } \\
\text { Manager. } \\
\text { - Limit use of aerial retardants within } 300 \text { feet of open } \\
\text { - } \quad \text { Smater or waterways. }\end{array}$ & $\begin{array}{l}\text { - Mechanical equipment should only be a last resort } \\
\text { during extreme drought to halt the spread of a } \\
\text { wildfire or to protect life and natural resources or } \\
\text { property, and under the recommendation of the } \\
\text { Natural Resource Manager. } \\
\text { - Limit use of aerial retardants within } 300 \text { feet of open }\end{array}$ \\
\hline
\end{tabular}




\begin{tabular}{|c|c|c|}
\hline & $\begin{array}{l}\text { neighbors. } \\
\text { - } \quad \text { Fuel moisture levels must sustain fire. }\end{array}$ & $\begin{array}{l}\text { water or waterways } \\
\text { - Soil conditions may make access difficult. }\end{array}$ \\
\hline $\begin{array}{l}\text { Special } \\
\text { Concerns }\end{array}$ & \multicolumn{2}{|c|}{ - Smoke may impact public health, traffic, BNL scientific facilities, and adjacent developments. } \\
\hline
\end{tabular}

\section{Planning}

\subsection{ANNUAL PLANNING}

Wildfire preparedness plans for BNL are periodically reviewed and updated by Emergency Services, Plant Engineering and the Natural Resource Manager. Updates are distributed to effected parties and record copies are filed at Building 599. The national wildland fire strategies include Annual Operations Plan, Detection and Dispatch Plan, Communications Plan, and the Pre-Attack Plan. BNL has adapted the elements of the national plan to fit local conditions. These adaptations are explained below. Although it is not exactly a "fire preparedness" plan, Prescribed Burn Plans (maintained by the Natural Resource Manager), which are also reviewed yearly, are part of the overall fire management strategy.

\subsubsection{Annual Operations Plan}

The Annual Operations Plan requires the following actions under the leadership of the Natural Resource Manager, working with the BNL Fire Rescue Group and the Wildfire Task Force of the Central Pine Barrens when necessary:

- Review Memoranda of Understanding (MOU) between DOE/BNL and outside agencies (NYSDEC and TNC)

- Review Suffolk County Mutual Aid Agreement. (Fire Chief)

- Update the detection and dispatch elements contained in BNL Fire Rescue Group's “Wildland Fire Response Procedure.” (Appendix E - Fire Chief)

- Review the communication plan elements and assigned radio frequencies in the "Brushfire Response Plan.” (Appendix E - Fire Chief)

- Review staffing and availability for prescribed fire planning. (Burn Boss of each prescribed fire)

- Review firebreak needs and identify the need for maintenance to Plant Engineering. (Fire Chief)

- Complete any needed updates to Prescribed Fire Plans and submit for review following Appendix D - Sample Prescribed Fire Plan, so they can be approved by the spring of each year. (Natural Resource Manager and Burn Boss)

- Carry out site preparation for prescribed burns. (Natural Resource Manager)

\subsubsection{Detection and Dispatch Plan}

Being in a suburban area, BNL relies on cooperators/neighbors, staff, and visitors to detect and report fires. Beyond that reliance on the general public for detection, there is no further detection plan in place. The national wildland fire "Detection and Dispatch Plan" requirements for dispatch are represented in BNL's documents by the "Wildland Fire Response Procedure" Standard Operating Procedure (http://intranet.bnl.gov/oem/emergmgmtlinks.asp). This procedure is reviewed and updated tri-annually. Copies are forwarded to the Suffolk County Fire/ Rescue communication center. Emergency Services maintains all their standard operating procedures (SOP) on the web (http://intranet.bnl.gov/oem/emergmgmtlinks.asp). 


\subsubsection{Communications Plan}

The national wildland fire standards for a Communications Plan specifies the means for firefighters to maintain contact. The conditions are inherent in the way business is conducted on Long Island and within fire departments of Suffolk County. It is part of standardized training offered within Suffolk County. Therefore, a separate Communication Plan Documents does not exist. The following list highlights theses conditions and explains how they are implemented.

- Intra -Complex - The BNL high band VHF radio system is the primary communication link for BNL operations involving BNL entities. Each piece of apparatus is assigned a mobile radio with BNL frequencies. Each firefighter and key person is assigned a portable with BNL frequencies. This is augmented by the use of cellular telephones for management personnel and key resources within the BNL emergency responder system.

- Fire Operations - Radios are issued to key positions and at least one per group while on fire operations. Local tactical frequencies are assigned during fire operations. As a back-up, cellular telephone are provided and tested to assure communications.

- Interagency - Suffolk County has a system of assigned low-band VHF radio frequency based on usage. The county is broken into divisions, with corresponding radio frequency channels assigned to groups of divisions. Mutual aid frequencies are established to facilitate responses involving large numbers of departments. However, departments often have adjacent divisions' frequencies within their radio units for smaller interagency operations. In the event of an incident needing Suffolk County interaction, BNL moves their radio operations to the Suffolk County frequencies (all BNL mobiles have low-band VHF Suffolk County radios). A limited number of extra BNL high-band VHF radios are also maintained by BNL to provide to Suffolk County and allow them to operate on BNL government frequencies, if needed.

\subsubsection{Pre-Attack Plan}

Pre-attack planning is outlined in BNL's "Wildland Fire Response Procedure” This SOP is updated tri-annually. Pre-attack resources are posted on the web and provided in the Command Vehicle. Preattack planning resources includes:

- Response map(s): structures, restricted areas, boundaries, roads, gates, trails, and water sources

- Mutual aid zones/fire coordinators' districts (includes map with boundaries)

- Hazard/Risk map: contaminated areas/zones, rivers and streams, power lines, main ditches, canals, and trenches

- Natural and Cultural Resources map: sensitive zones, non-sensitive zones, restricted vehicle access areas

- Structure use list

\subsubsection{Prescribed Burn Plan}

The Prescribed Burn Plans are described in Section VI of this document.

\subsection{FIRE WEATHER AND NFDRS INDICES}

The Long Island National Wildlife Refuge Complex and the Central Pine Barrens Joint Planning and Policy Commission maintain automated weather stations. FWS operates their station throughout the year, except during a two-week period in winter when the sensors are serviced. At that time, FWS uses the Eastport, Long Island Fire Weather Station to monitor fire weather conditions.

Throughout the fire season, the Natural Resource Manager and the Emergency Management Manager will monitor the NFDRS indices and prepare Fire Behavior Model runs (BEHAVE) for potential 
critical fire activity, based on drought severity (on the KBDI scale, see Appendix A), 1000-hour fuel moisture, and associated weather trends that may contribute to limits of acceptable fire control.

Fire weather is provided to Suffolk County Fire Rescue and Emergency Services (SCFRES) on a daily basis. SCFRES communicators announce the fire weather on the dispatcher frequency (46.46) each day at approximately 1400 hours. An alert is issued by BNL Fire/Rescue during High or Extreme fire weather.

\subsection{WILDLAND-URBAN INTERFACE}

As urban/suburban development continues, cooperative planning with the NYSDEC Forest Rangers will be necessary to ensure public and resource protection and safety. BNL must plan for an increasing wildland-urban interface. Wildland-urban interface planning includes:

- Identify and map facilities, resources, and adjacent public and private property that need protection.

- Use mechanical (and potentially chemical) means, and possibly prescribed fire to reduce fuel and create firebreaks.

- Participate in public information and education programs provided by the Wildfire Task Force of the Central Pine Barrens.

\subsection{NORMAL UNIT STRENGTH (NUS)}

\subsubsection{Staffing and Qualifications}

The table located in Appendix D indicates the adequate staffing for the BNL fire program. These positions should be identified and available for assistance from within BNL staff and "Cooperators" (neighboring jurisdictions).

Qualification information, such as training records and fire assignments, are maintained through the Fire Management Information System (FMIS), which is a FWS/DOI computer data base system. Information is updated annually. BNL maintains a file on personnel to document the training each individual receives.

Cooperators for the fire program at BNL include several local volunteer fire departments, the BNL Fire Department, The Nature Conservancy (TNC), and the NYSDEC Forest Rangers. All cooperators will meet their own agency requirements and NWCG or equivalent requirements for training, personal protective equipment, and fitness standards for working on wildfires.

\subsubsection{Equipment}

The BNL Fire Department is supplied and staffed and is capable of handling initial response to all emergencies on site. In addition to the resources of the BNL Fire Department, the following supplies are available through interagency mutual aid if conditions warrant:

1. Slip-on units are loaded and fully functional. The engine is outfitted to a type VII standard, as described in the NWCG Fire Line Handbook.

2. The fire cache is adequately supplied.

3. A dozer and fire plow are available for all critical fire activity periods.

4. All portable pumps are functional, and pump kits are complete. Pump fuel is mixed and available.

5. Chainsaws are all functional and available.

6. Hand tools are adequately maintained and safe to use. 
7. 3,000 gallon water tanker - filled and on standby.

\subsubsection{Personal Protective Equipment (PPE) - Prescribed Fire Only}

All firefighters will be issued from the cache the required personal protective equipment. This includes Nomex pants and shirts, gloves, helmet and goggles (as required for duties), field pack with complete fire shelter, and a personal first aid kit.

\subsubsection{Engine}

BNL engine 3 (Brush truck) is the primary initial attack resource on wildfires. Engines $1 \& 2$ are secondary pumpers which carry water but have a limited ability to go off hardpan. These resources are staffed 24 hours a day all year round.

\subsubsection{Annual Training and Refresher}

The goal of BNL fire training is to maintain fully qualified individuals to meet the objectives of this plan. Employee development training is a second priority, depending on budget limitations. To reduce training costs, BNL takes advantage of training programs offered locally through the annual NY State Wildland Fire and Incident Command Academy held at BNL, and the Suffolk County Fire Academy.

All personnel involved in prescribed fire management activities are required to participate in 8 hours of fire management refresher training annually to be qualified for fire management activities in that calendar year. Refresher training concentrates on local conditions and factors, the Standard Fire Orders, "Look Outs, Communications, Escape Routes and Safety Zones” (LCES), "18 Situations and Common Denominators,” NWCG courses: Standards for Survival; Lessons Learned; Look Up, Look Down, Look Around; and others to meet the firefighter safety requirement. Efforts are made to vary the training and use all or portions of other NWCG courses to cover the required topics. Annual training includes practice on how to deploy and use a fire shelter under simulated adverse conditions. Annual training includes a review of BNL's fire procedures and the operation of all BNL fire equipment as applicable to specific duties.

\subsubsection{Physical Fitness}

All fire personnel involved in federal fire management activities must meet the fitness standards established by their agency. The BNL Fire Department uses the National Fire Protection Association's Standard 1500, Occupation Health and Safety Program. This includes an annual physical and stress test.

Firefighters participating in prescribed fire management activities on the fireline must achieve and maintain an "arduous" rating. Individuals achieving a "moderate" or "light" rating may participate in prescribed fire activities through supporting roles (e.g. fire weather, smoke spotter, etc.). Anyone practicing for a physical fitness test or actually taking a physical fitness test must first read and sign the PAR-Q health-screening questionnaire and an informed consent form. If a person who is being tested to achieve a "moderate" or "arduous" rating answers "yes” to any of the questions in the PAR$\mathrm{Q}$ health screening questionnaire, the test administrator recommends a physical examination prior to training or the test. Furthermore, an exam is required for individuals over 40 years of age. A trained and qualified American Red Cross Responder (or equivalent) who can recognize symptoms of physical distress and administer appropriate first aid procedures must be on the site during the fitness test. Fitness tests shall not be administered to anyone who has obvious physical conditions or known heart problems that would place them at risk. 


\section{IV - Suppression Operations}

\subsection{SUPPRESSION PLANNING}

With careful planning, land managers can reduce the damage resulting from wildfires and wildfire suppression in all areas of BNL. This is especially important in developed facilities, critical research areas, contaminated areas, habitat crucial to threatened and endangered species, and cultural or historical sites. Areas susceptible to wildfire risk have been identified and methods have been implemented to reduce the probability of a damaging fire. These actions are included in the PreAttack Plan for each Fire Management Unit. These actions are communicated to suppression forces through annual training and through briefings in times of actual fire.

\subsection{INITIAL ATTACK}

For any wildfires occurring at BNL, the BNL Fire Department is in charge of all suppression activities. An initial attack is a response that does not exceed 24 hours' duration, threaten persons or property off site, or require additional forces from outside BNL. Due to the nature of the BNL site and its proximity to two outside fire districts, wildland fires are occasionally detected and responded to by outside fire departments. These departments inform the BNL Fire Department of their actions. This type of situation would be included as an "Initial Attack" classification.

\subsection{RESOURCE ADVISOR}

A resource advisor (RA) is someone who is responsible for gathering and analyzing information concerning critical areas and natural resources that may be impacted by fire or fire suppression activities. At BNL, the Natural Resource Manager is the RA. This person is a crucial link between the fire suppression forces and the Lab. This person reports to the Planning Chief as a technical resource.

\subsection{EXTENDED ATTACK}

An extended attack is required when a fire is likely to last longer than 24 hours, threatens adjacent public or private lands, or exceeds the capabilities of the BNL Fire Department assisted by on-site fire-trained personnel. The DOE Area Manager or designate is notified upon extended attack actions, and may coordinate with appropriate BNL officials. Actions may include:

- Completing a Delegation of Authority form (Appendix C), if needed

- Completing a Wildland Fire Situation Analysis (WFSA) and holding a daily review of that plan with the necessary parties

- Notifying DOE to request additional state and federal resources 


\section{V - Prescribed Burns}

Each prescribed burn has a unique set of goals or objectives. After each prescribed burn is completed, a report is produced (general as part of the Annual Report on activities associated with the Natural Resource Management Plan), documenting the amount of fuel reduction, extent of invasive species reduced, and so on. If the goals were not achieved the report will also state what could have been done differently to achieve the objectives. Some goals require pre- and post-fire vegetation monitoring for accurate evaluation; post-fire monitoring can extend for up to five years.

\subsection{PROGRAM OVERVIEW}

The Central Pine Barrens of Long Island is a fire-adapted vegetative type that, in the absence of fire, will change in composition and structure and adversely affect other natural resources. The purpose of the BNL/Upton Reserve Prescribed Fire Program is 1) to use fire as a controlled, management tool for reducing available fuel, 2) to maintain fire-dependent communities such as pine barrens habitats and warm-season grasslands, and 3) to reduce or eliminate exotic nuisance vegetation. The Natural Resource Manager is the lead for developing and implementing the Annual Prescribed Fire Program working in cooperation and coordination with BNL Fire Rescue, NYSDEC, and TNC.

\section{$5.2 \quad$ LIMITS ON PRESCRIBED BURNING}

Most prescribed burning will be low to moderate in complexity. Only wildfire-qualified persons with training and the skills necessary to plan, execute, and evaluate the burn program will be used. Usually a burn crew consists of a qualified Burn Boss and additional fire-qualified individuals. Additional team members may be requested as required from the New York State Forest Rangers, BNL Fire Department, TNC, other qualified cooperators and partners, and local volunteer fire departments.

The following limits have been identified for the Prescribed Fire Program:

- Air quality must be maintained; a NYSDEC open burning permit is required (NYSDEC approval of Prescribed Fire Plan serves as open burn permit).

- Public safety must not be endangered by the location or extent of a prescribed burn.

- The prescribed fire must not negatively impact the wildland-urban interface.

- Staffing requirements must be met, despite transfers of fire-trained individuals.

- A qualified Burn Boss (minimum Level II) must be available.

- TNC, DEC, BNL or cooperator burn crews must be available.

- Appropriate pre-fire soil and vegetation sampling characterization or analysis data must be done.

- No known radioactively contaminated soils/vegetation may be involved.

- Personnel must establish and review safety criteria.

- Area to be burned must be within fuel breaks or appropriate fire lines established for each burn.

- Go/No Go checklist must be completed and approved by DOE and BNL designated managers.

\subsection{SMOKE MANAGEMENT}

To minimize negative impacts to visibility and to maintain air quality, plans for prescribed burns must provide for aggressive action to manage smoke. Visibility and clean air are primary natural resource 
values and the protection of these resources is given full consideration in fire management planning and operation. BNL complies with all applicable federal, state, interstate, and local air pollution control requirements, as specified within Section 118 of the Clean Air Act, as amended (42 USO 7418). That Act establishes Class I, II, and III areas, where emissions of particulate matter and sulfur dioxide are to be restricted. The restrictions are most severe in Class I areas, wilderness areas exceeding 500 acres. However, BNL contains no federally designated wilderness areas.

New York State has developed several implementation plans to administer the Clean Air Act. A permit for prescribed burning must be obtained from the New York State Department of Environmental Conservation.

A section on smoke management is included in each prescribed fire, detailing specific actions to be taken to mitigate the impacts of smoke. Aggressive mop-up must be initiated on wildfires that have the potential to produce levels of smoke that may impact human health or safety.

\subsection{APPROVALS}

BNL's Natural Resource Manager working with expertise at the NYS Forest Rangers and TNC will annually formulate the prescribed burn program and assign a burn boss. The burn boss will review the Prescribed Burn Plan (see blank version in Appendix D), which is submitted for technical review to the NYSDEC Forest Rangers upon which approval constitutes a burn permit.

The only permit required from local agencies is an Open Burning Permit, obtained through the NYS Forest Rangers. The permit specifies the day, time, and type of burn being conducted, the responsible individual, and type of holding resources on site. There are no air quality permits required; however, careful monitoring of changing state regulations is necessary to ensure any open burning is done in compliance with existing regulations. All prescribed burning restrictions or notifications imposed at the state, regional, or national level, as determined by preparedness level, shall be adhered to.

Review of a prescribed burn plan serves as both the safety review and work planning documentation. The final approval for any prescribed fire at BNL comes from the DOE Area Manager.

Work associated with the preparation of a prescribed fire unit must be covered under the work planning and work permit process and documents.

\section{$5.5 \quad$ BURNING SEASON}

The primary prescribed fire burn season ranges from September 1 to April 30. However, weather conditions, opportunities, or objectives may allow burns to be conducted any time during the year. A Prescribed Fire Plan (Appendix D) is a thorough document that details who, what, when, where, and why the burn will be done.

\subsection{COMPLEXITY}

Complexity for individual burns is calculated using the National Wildfire Coordinating Group (NWCG) Prescribed Fire Complexity Rating Guide. This guide requires planners to consider the following factors:

1. Potential for escape

2. The number and dependence of activities

3. Values of property at risk 
4. Fuels/Fire behavior

5. Size of prescribed burn team

6. Magnitude of oversight/political activities

7. Fire treatment objectives

8. Environmental constraints

9. Safety

10. Ignition procedures/methods

11. Interagency problems

12. Project logistics

13. Special features inside fire area

14. Smoke management

15. Fuel breaks

The overall rating is assigned as Low, Moderate, or High, based on the potential risk, potential consequence, and technical difficulty of each element. This in turn helps to establish the degree of difficulty that is involved, suggest whether the personnel resources available can execute the planned fire, and identify specific elements or characteristics of a planned burn that pose special problems or concerns. In short, it can be thought of as a "Go, No Go" checklist to a planned event before the fire is ignited.

Once the complexity of a proposed burn has been calculated, that index is stated in the Prescribed Burn Plan. Many of the planned burns at BNL would ordinarily be in the Low complexity category. However, air quality considerations and BNL's proximity to developments and busy highways may elevate some burns to the Moderate complexity level.

\subsection{PREPARATION AND IMPLEMENTATION}

Site preparation needs are identified and specified within the Prescribed Burn Plan. These will be carried out prior to ignition, and approved by the burn boss. The burn boss may impose additional site preparation needs or request additional holding requirements based on potential escape and risk involved. No prescribed burning will occur when a wildfire is in progress within BNL, when fire danger indices are above "moderate," or when New York State or Suffolk County has issued a burning restriction.

\subsection{MONITORING AND EVALUATION}

All prescribed burning performed at BNL is documented by BNL personnel. Additional monitoring needs for fuel reduction and habitat response consist mainly of photos that show whether the burn objectives and resource objectives have been accomplished. No special equipment is necessary for monitoring fire behavior. Most burns are of low to moderate intensity, easily measured through rate of spread and flame-length observations. Should more conclusive fire behavior and effects information be necessary; it will be documented within the Annual Prescribed Burn Planning process.

\subsection{GUIDELINES FOR PRESCRIBED BURNS AT BNL AND UPTON RESERVE}

For the type of prescribed burning occurring at BNL, follow these guidelines:

- Obtain a prescribed burning permit from NYSDEC. 
- Conduct the burn according to the terms and conditions of the permit.

- Burn only when existing wind speed, wind direction, and atmospheric conditions (such as inversions or when stagnant air conditions are evident) will not create any nuisance conditions. Burn on days when wind directions will carry smoke away from sensitive areas.

- Conduct burning only when visibility exceeds four miles and when the fire weather forecast indicates that mixing heights are greater than $1500 \mathrm{ft}$ and any unstable air mass is at least that distant.

- Burn when fuels are reasonably dry, at least one day after a precipitation event.

- Reduce residual smoke by mopping up stumps and snags quickly.

- Do not burn if the state, county, or any other governing agency has issued an air pollution health advisory, alert, warning, or emergency.

- Use backing and flanking fires, when possible, to minimize particulate emissions. (Back and flank fires emit 3 to 5 times less particulate matter than head fires.)

- Inform media and other public affairs offices of fire and smoke dispersal conditions throughout the burn.

- Ensure proper approvals - BNL Management, BNL Fire Chief, DOE Area Manager (No prescribed fire action will be conducted without BNL and DOE approval on Go/No Go checklist). 


\section{VI - Community Factors}

\subsection{PUBLIC SAFETY}

Safety of wildland firefighters, prescribed fire burn crews, and the general public is the priority goal. This section deals with the safety of the visiting public and BNL's neighbors. In several sections of this plan, references have been made regarding the safeguarding of human life. The references have been in two forms: reducing fuel loadings to lessen the intensity of wildfires, and managing wildfires and prescribed burns in such a manner as to reduce the likelihood of accidents or injuries. The following actions will be taken to safeguard human life:

- The fuels in the wildland-urban interface will be managed in a manner that is designed to reduce fuel loadings near human habitation.

- All prescribed fire operations will be conducted in accordance with an approved plan.

- All prescribed fire operations will be conducted in accordance with all applicable federal and state laws, regulations, and policy statements.

- Specific actions to be taken during prescribed burns will be indicated in prescribed burn plans.

The greatest concern is the safety of all suppression personnel and the public when a wildland fire or prescribed burn is in progress. Only properly trained and qualified personnel shall be assigned. Unqualified individuals at the incident should be relieved from suppression duty or be reassigned to a non-fireline function when adequate initial attack forces arrive. The fire scene must be secured from the public for their own protection. Depending on the complexity of the incident, access may have to be controlled.

\subsection{PUBLIC INFORMATION AND EDUCATION}

The BNL Community, Education, Governmental and Public Affairs (CEGPA) group, working with the NYSDEC Forest Rangers and the Long Island Pine Barrens Commission will use existing prevention and public education programs regarding fire on wildlands. Additional public education materials on fire may be developed and shared with BNL's employees and stakeholders. Public education is necessary to garner support and understanding for any fire management program.

Within the Incident Command System, an Information Officer position is identified. This person is responsible for formulating and releasing information about an incident to the news media, incident personnel, and other agencies. Communications to the news media, other non-regulatory agencies, and so on are presented through the BNL Media and Communications group. Prescribed burns will be communicated through the BNL Community Involvement program. The BNL Wildland Fire Hazard Severity Analysis, Issues and Needs document (Appendix G) is a detailed document that covers specific issues concerning community factors. 


\section{VII - References \& Supporting Literature}

Anderson, H.A. 1982. Aids to Determining Fuel Models for Estimating Fire Behavior. Gen. Tech. Rep. INT122.Ogden, UT: U.S. Department of Agriculture, Forest Service, Intermountain Forest and Range Experiment Station.

Barbour, M.G. and W. D. Billings. 1988. North American Terrestrial Vegetation. Cambridge University Press. $434 \mathrm{pp}$.

BNL. 2008. 2007 Site Environmental Report. Prepared by Brookhaven Science Associates for the U.S. Department of Energy.

DOE. 2003. Order 450.1: Environmental Protection Program. (1-15-03).

DOI. Final Environmental Impact Statement, Brookhaven National Laboratory. 1977. Energy Research and Development Administration.

DOI. Fire Management Handbook, 1993, updated 2000

DOI. Phase II Sitewide Biological Inventory Report. 1995. Prepared by CDM Federal Programs Corporation and Lawler, Matusky \& Skelly Engineers for the Office of Environmental Restoration, Brookhaven National Laboratory.

DeBano, L.F., D.G. Neary, and P.F. Folliott. 1998. Fire’s Effects on Ecosystems. John Wiley and Sons, New York. 333 pp.

EPA. Clean Air Act as Amended 1990, Section 118, Control of Pollution from Federal Facilities.

Heinselman, M.L., 1973. “Fire in the Virgin Forest of the Boundary Waters Canoe Area.” Minnesota Quat. Res. 3:329-382.

Heinselman, M.L. 1981. "Fire Intensity and Frequency as Factors in the Distribution and Structure of Northern Ecosystems.” In Fire Regimes and Ecosystem Properties, USDA. For. Ser. GTR WO-26, pp. 7-47.

Olsvig, L.S., J.F. Cryan, and R.H. Whittaker. 1979. "Vegetational Gradients of the Pine Plains and Barrens of Long Island, New York.” In Pine Barrens Ecosystem and Landscape. Rutgers University Press. 601 pp.

Pyne, S.J. 1995. World Fire. The Culture of Fire on Earth. Holt.

Pyne, S.J. 1997 a. Fire in America: A Cultural History of Wildland and Rural Fire. University of Washington Press.

Pyne, S.J. 1997 b. America's Fires, Management on Wildlands and Forests. Forest History Society, Durham. NC. 55 pp.

Villani, R. 1997. Long Island: A Natural History. Harry Abrams Publishing, New York. 192 pp.

USDA. 1999. Fire Family Plus User’s Guide. Rocky Mountain Research Station, Fire Sciences Lab. 


\section{Appendix A: Definitions and Acronyms}

\begin{tabular}{|c|c|}
\hline Agency Administrator & $\begin{array}{l}\text { Appropriate-level manager with organizational responsibility for } \\
\text { managing an administrative unit. Varies with the group but includes: } \\
\text { BLM - Director, State Director, District Manager, Field Manager } \\
\text { DOE - Area or Site Office Manager } \\
\text { FWS - Director, Regional Director, Complex Manager, Project Leader } \\
\text { NPS - Director, Regional Director, Park Superintendent, Unit Manager } \\
\text { BIA - Director, Office of Trust Responsibility, Area Director, } \\
\text { Superintendent }\end{array}$ \\
\hline Anchor Point & $\begin{array}{l}\text { Advantageous location, generally a fire barrier, from which to start } \\
\text { constructing a fire line; used to minimize the chance of being outflanked } \\
\text { by the fire while the line is being constructed. }\end{array}$ \\
\hline Appropriate Management Action & Specific actions taken to implement a management strategy. \\
\hline $\begin{array}{l}\text { Appropriate Management } \\
\text { Response }\end{array}$ & $\begin{array}{l}\text { Specific actions taken in response to a wildland fire to implement } \\
\text { protection measures and meet fire-use objectives. }\end{array}$ \\
\hline $\begin{array}{l}\text { Appropriate Management } \\
\text { Strategy }\end{array}$ & $\begin{array}{l}\text { Plan or direction, selected by an agency administrator, that guides fire } \\
\text { management actions to meet protection and fire-use objectives. }\end{array}$ \\
\hline Appropriate Suppression & $\begin{array}{l}\text { Selecting and implementing a prudent suppression option to avoid } \\
\text { unacceptable impacts and provide for cost-effective action. }\end{array}$ \\
\hline Backing fire & $\begin{array}{l}\text { Predetermined strategy for setting a fire along the inner edge of a fire } \\
\text { line to consume fuel in the path of a wildfire and/or change the direction } \\
\text { of force of the fire's convection column. }\end{array}$ \\
\hline Bureau & Bureaus, offices, or services of the Department of the Interior. \\
\hline $\begin{array}{l}\text { Burning Index } \\
\text { (BI) }\end{array}$ & $\begin{array}{l}\text { Estimate of the potential difficulty of containing a fire, related to the } \\
\text { flame length at the head of a fire. BI divided by a factor of } 10 \text { indicates } \\
\text { approximate flame length. The BI traces seasonal trends reasonably } \\
\text { well and is used by the agency for determining initial action resource } \\
\text { needs (Step-Up Planning) based on fire potential only. }\end{array}$ \\
\hline Burning out & $\begin{array}{l}\text { Setting fire inside a control line to consume fuel between the edge of } \\
\text { the fire and the control line. Used to widen control lines during line } \\
\text { construction or to eliminate unburned fuels inside the control lines after } \\
\text { containment. }\end{array}$ \\
\hline $\begin{array}{l}\text { Chain } \\
\text { (ch) }\end{array}$ & $\begin{array}{l}\text { Unit of measure equal to } 66 \text { feet. } 80 \text { ch equals } 1 \text { mile; } 10 \text { square ch } \\
\text { equals } 1 \text { acre. Commonly used to report fire perimeters and calculate } \\
\text { fire size. }\end{array}$ \\
\hline Class (size of wildland fire) & $\begin{array}{l}\text { Class } A-1 / 4 \text { acre or less } \\
\text { Class B - more than } 1 / 4 \text { but less than } 10 \text { acres } \\
\text { Class } C-10 \text { acres to } 100 \text { acres } \\
\text { Class D - } 100 \text { to } 300 \text { acres } \\
\text { Class E - } 300 \text { to } 1,000 \text { acres } \\
\text { Class F - } 1,000 \text { to } 5,000 \text { acres } \\
\text { Class G }-5,000 \text { acres or more }\end{array}$ \\
\hline
\end{tabular}




\begin{tabular}{|c|c|}
\hline Cold trailing & $\begin{array}{l}\text { Method of confirming what appears to be a dead fire edge by careful } \\
\text { inspection and feeling with the hand to detect any fire, and } \\
\text { extinguishing it by digging out every live spot and trenching any live } \\
\text { edge. }\end{array}$ \\
\hline Confine/Contain/Control & $\begin{array}{l}\text { These terms, when used in the context of suppression strategies, are } \\
\text { confusing because they also have tactical meanings. Confine is to keep } \\
\text { within bounds or to restrict. For fire reporting purposes, containment } \\
\text { implies the completion of a fire line around a fire and any associated } \\
\text { spot fires; this can reasonably be expected to stop the fire's spread. } \\
\text { Control is a point in time where fire suppression actions have removed } \\
\text { any threat of fire spread. }\end{array}$ \\
\hline Convection column & Rising air generated by a fire. \\
\hline Duff & Accumulated leaf litter and decaying vegetation on a forest floor. \\
\hline $\begin{array}{l}\text { Emergency Fire Rehabilitation/ } \\
\text { Burned Area Emergency } \\
\text { Rehabilitation } \\
\text { (EFR/BAER ) }\end{array}$ & $\begin{array}{l}\text { Emergency actions taken during or after wildland fire to stabilize and } \\
\text { prevent unacceptable resource degradation or to minimize threats to life } \\
\text { or property resulting from the fire. The scope of EFR/BAER projects is } \\
\text { unplanned and unpredictable, requiring funding on short notice. }\end{array}$ \\
\hline $\begin{array}{l}\text { Energy Release Component } \\
\text { (ERC) }\end{array}$ & $\begin{array}{l}\text { Number related to the available energy (BTU) per unit area (square } \\
\text { foot) within the flaming front at the head of a fire. The National Fire } \\
\text { Danger Rating System, a computer model of fire weather and its effect } \\
\text { on fuels, generates the ERC. The ERC incorporates thousand-hour } \\
\text { dead fuel moistures and live fuel moistures. Day-to-day variations are } \\
\text { caused by changes in the moisture content of the various fuel classes. } \\
\text { The ERC is derived from predictions of } 1 \text { ) the rate of heat release per } \\
\text { unit area during flaming combustion, and } 2 \text { ) the duration of flaming. }\end{array}$ \\
\hline Extended attack & $\begin{array}{l}\text { Fire response where initial attack forces are reinforced by additional } \\
\text { forces, or an attack lasting longer than one } 24-\mathrm{hr} \text { period. }\end{array}$ \\
\hline Fire break & $\begin{array}{l}\text { Natural or constructed barrier used to stop or slow the spread of a fire } \\
\text { or to provide a control line from which to work. }\end{array}$ \\
\hline Fire effects & $\begin{array}{l}\text { Any consequences to the vegetation or the environment resulting from } \\
\text { fire, whether neutral, detrimental, or beneficial. }\end{array}$ \\
\hline Fire hazard & $\begin{array}{l}\text { Fuel complex-defined by volume, type, condition, arrangement, and } \\
\text { location-that determines the degree and ease of ignition and/or } \\
\text { resistance to control. }\end{array}$ \\
\hline Fire intensity & $\begin{array}{l}\text { Amount of heat produced by a fire. Usually compared by reference to } \\
\text { the length of the flames. }\end{array}$ \\
\hline Fire line & $\begin{array}{l}\text { Removal or alteration of fuel from a narrow area of a control line by the } \\
\text { use of hand tools and power equipment to control a fire. It implies } \\
\text { mineral soil exposure. }\end{array}$ \\
\hline $\begin{array}{l}\text { Fire Management Plan } \\
\text { (FMP) }\end{array}$ & $\begin{array}{l}\text { Strategic plan that defines a program to manage wildland and } \\
\text { prescribed fires and documents the Fire Management Program in the } \\
\text { approved land use plan. The FMP is supplemented by operational } \\
\text { procedures such as preparedness plans, preplanned dispatch plans, } \\
\text { prescribed fire plans, and prevention plans. }\end{array}$ \\
\hline $\begin{array}{l}\text { Fire Management Unit } \\
\text { (FMU) }\end{array}$ & $\begin{array}{l}\text { Area where there are common fire management goals, objectives, and } \\
\text { fuels, and where resource uses have been defined. The size of the unit } \\
\text { is not important; however, the FMU should relate well to the strategies } \\
\text { for managing wildland and prescribed fires that are defined in the Fire } \\
\text { Management Plan. }\end{array}$ \\
\hline Fire management & $\begin{array}{l}\text { All activities related to prudently managing people and equipment to } \\
\text { prevent or suppress wildland fire and to use fire under prescribed } \\
\text { conditions to achieve land and resource management objectives. }\end{array}$ \\
\hline
\end{tabular}




\begin{tabular}{|c|c|}
\hline Fire prescription & $\begin{array}{l}\text { Written direction for the deliberate use of fire to treat a specific piece of } \\
\text { land. A fire prescription specifies the acceptable range of the various } \\
\text { fire-related indices (temperature, humidity, wind direction and speed, } \\
\text { fuel and soil moisture) and the limit of the area to be burned. }\end{array}$ \\
\hline $\begin{array}{l}\text { Fire-suppression activity } \\
\text { damage }\end{array}$ & $\begin{array}{l}\text { Damage to lands, resources, and facilities directly attributable to the fire } \\
\text { suppression effort or activities, including: dozer lines, camps and } \\
\text { staging areas, facilities (fences, buildings, bridges), fire lines, and } \\
\text { roads. }\end{array}$ \\
\hline FMIS & Fire Management Information System, a computer database. \\
\hline Fuel break & $\begin{array}{l}\text { Natural or constructed barrier used to stop or slow the spread of a fire } \\
\text { or to provide a control line from which to work. }\end{array}$ \\
\hline Fuel loadings & Amount of burnable fuel on a site, usually given as tons/acre. \\
\hline Fuels & $\begin{array}{l}\text { Materials that are burned in a fire: primarily grass, surface litter, duff, } \\
\text { logs, stumps, brush, foliage, and live trees. }\end{array}$ \\
\hline Hazard fuels & $\begin{array}{l}\text { Vegetative fuels that, when ignited, threaten public safety, structures } \\
\text { and facilities, cultural and natural resources, and natural processes. }\end{array}$ \\
\hline Hazard reduction & $\begin{array}{l}\text { Manipulation or removal of fuels to reduce the likelihood of ignition and } \\
\text { lessen potential damage of wildfire. Normally done to reduce the } \\
\text { chance of a major fire but can also be done to protect the resource or } \\
\text { facility. }\end{array}$ \\
\hline IC & Incident Commander \\
\hline $\begin{array}{l}\text { Incident Command System } \\
\text { (ICS) }\end{array}$ & $\begin{array}{l}\text { Combination of facilities, equipment, personnel, procedures, and } \\
\text { communications operating within a common organizational structure } \\
\text { with responsibility for managing assigned resources to effectively } \\
\text { accomplish specific objective(s) pertaining to an incident. }\end{array}$ \\
\hline Indirect attack & $\begin{array}{l}\text { Method of fire suppression in which the control line is located a } \\
\text { considerable distance from the fire's edge. Often used when a fire has } \\
\text { a rapid rate of spread or high intensity, to utilize natural or constructed } \\
\text { firebreaks or fuel breaks and favorable breaks in topography. Fuel } \\
\text { between the control line and fire front is usually removed by deliberate } \\
\text { burning, but sometimes the main fire is allowed to burn to the control. }\end{array}$ \\
\hline Initial attack & $\begin{array}{l}\text { Aggressive suppression action consistent with firefighter and public } \\
\text { safety and values to be protected, usually limited to } \sim 24 \text { hours. }\end{array}$ \\
\hline $\begin{array}{l}\text { Ketch-Byram Drought Index } \\
\text { (KBDI) }\end{array}$ & $\begin{array}{l}\text { Soil/duff drought index that ranges from } 0 \text { (no drought) to } 800 \text { (extreme } \\
\text { drought), based on soil capacity of } 8 \text { inches of water. Index factors are } \\
\text { maximum daily temperature and daily and annual precipitation. }\end{array}$ \\
\hline Ladder fuels & $\begin{array}{l}\text { Fuels that provide vertical continuity between strata. Convection moves } \\
\text { the fire from surface fuels into the crowns with relative ease. }\end{array}$ \\
\hline LCES & $\begin{array}{l}\text { "Look Outs, Communications, Escape Routes and Safety Zones" } \\
\text { (a safety policy and also the title of a fire training course). }\end{array}$ \\
\hline Maintenance burn & $\begin{array}{l}\text { Fire set by agency personnel to remove debris; i.e., leaves from } \\
\text { drainage ditches or cuttings from tree pruning. Such a fire does not } \\
\text { have a resource management objective. }\end{array}$ \\
\hline Mixing height & Height that smoke will rise in atmosphere. \\
\hline Mop-up & The act of making a fire safe after it is controlled. \\
\hline Mutual aid & $\begin{array}{l}\text { Free assistance from one fire agency to another during an emergency, } \\
\text { based on prearrangement between them and generally at the request } \\
\text { of the receiving agency. }\end{array}$ \\
\hline Natural fire & Fire of natural origin, caused by lightning or volcanic activity. \\
\hline NFDRS & National Fire Danger Rating System \\
\hline
\end{tabular}




\begin{tabular}{|c|c|}
\hline NFDRS Fuel Model & $\begin{array}{l}\text { One of } 20 \text { mathematical models used by the NFDRS to predict fire } \\
\text { danger. The models were developed by the US Forest Service and are } \\
\text { general rather than site specific. }\end{array}$ \\
\hline NFFL & Northern Forest Fire Laboratory, at Missoula, Montana \\
\hline NFFL Fuel Model & $\begin{array}{l}\text { One of } 13 \text { mathematical models used to predict fire behavior within the } \\
\text { conditions of their validity. US Forest Service personnel at NFFL } \\
\text { developed the models. }\end{array}$ \\
\hline $\begin{array}{l}\text { Normal Unit Strength } \\
\text { (NUS) }\end{array}$ & $\begin{array}{l}\text { Amount of noncapitalized fire fighting equipment needed to meet } 70 \\
\text { percent of suppression needs. }\end{array}$ \\
\hline $\begin{array}{l}\text { National Wildfire Coordinating } \\
\text { Group } \\
\text { (NWCG) }\end{array}$ & $\begin{array}{l}\text { National interagency operational group authorized by the Secretaries of } \\
\text { Agriculture and the Interior, designed to coordinate fire management } \\
\text { programs of the participating agencies. The group provides a platform } \\
\text { to agree upon policy, standards of training, equipment, aircraft, } \\
\text { suppression priorities, and other operational considerations. }\end{array}$ \\
\hline Preparedness & $\begin{array}{l}\text { Activities that lead to safe, efficient, and cost-effective fire management } \\
\text { in support of land and resource management objectives through } \\
\text { appropriate planning and coordination. Preparedness actions taken } \\
\text { seasonally include hiring and training personnel; making ready vehicles, } \\
\text { equipment, and facilities; acquiring supplies; and updating agreements } \\
\text { and contracts. }\end{array}$ \\
\hline Prescribed burn, prescribed fire & $\begin{array}{l}\text { Fire ignited by agency personnel in accord with an approved plan and } \\
\text { under prescribed conditions, designed to achieve measurable resource } \\
\text { management objectives. Such a fire is designed to produce the } \\
\text { intensities and rates of spread needed to achieve one or more planned } \\
\text { benefits to natural resources. Its purpose is to employ fire scientifically } \\
\text { to realize maximum net benefits at minimum impact and acceptable } \\
\text { cost. A written, approved prescribed fire plan must exist and NEPA } \\
\text { requirements must be met, prior to ignition. NEPA require-ments can be } \\
\text { met at the land-use or fire management planning level. }\end{array}$ \\
\hline Prescription & $\begin{array}{l}\text { Measurable criteria that guide the selection of appropriate management } \\
\text { response and actions. Prescription criteria may include safety, } \\
\text { economic, public health, and environmental, geographic, administrative, } \\
\text { social, or legal considerations. }\end{array}$ \\
\hline Prevention & $\begin{array}{l}\text { Activities directed at reducing the number or the intensity of fires that } \\
\text { occur, primarily by reducing the risk of human-caused fires. }\end{array}$ \\
\hline Rehabilitation & $\begin{array}{l}\text { Actions to mitigate the adverse effects of suppression of a wildland fire } \\
\text { on the vegetation-soil complex, watershed, and other features. }\end{array}$ \\
\hline Resource Advisor & $\begin{array}{l}\text { Resource specialist responsible for gathering and analyzing information } \\
\text { concerning natural resources and their uses that may be affected by a } \\
\text { fire or by fire suppression activities. }\end{array}$ \\
\hline Spread Component (SC) & Rating of the forward rate of spread of a head fire. \\
\hline Slip-on pump unit & $\begin{array}{l}\text { Firefighting pump that is lifted onto a flatbed truck or utility vehicle. } \\
\text { Equipped at a minimum with pump, hose reel, and water tank. }\end{array}$ \\
\hline Smoke-sensitive area & $\begin{array}{l}\text { Area, including designated wilderness areas, where smoke from } \\
\text { outside sources is intolerable, for reasons such as heavy population, } \\
\text { existing air pollution, or intensive recreation or tourist use. }\end{array}$ \\
\hline Strategy & $\begin{array}{l}\text { Overall plan of attack for fighting a fire, considering the most cost- } \\
\text { efficient use of personnel and equipment in relation to values } \\
\text { threatened, fire behavior, legal constraints, and objectives established } \\
\text { for managing natural resources. Actual decisions on tactical use of } \\
\text { personnel and equipment are left to the assigned Incident Commander. }\end{array}$ \\
\hline Suppression & $\begin{array}{l}\text { Management action intended to protect identified values from a fire, } \\
\text { extinguish a fire, or alter a fire's direction of spread. }\end{array}$ \\
\hline
\end{tabular}




\begin{tabular}{|l|l|}
\hline Tactics & $\begin{array}{l}\text { Planned operational actions that determine specific fire suppression } \\
\text { measures to extinguish a fire. They must be consistent with the strategy } \\
\text { established for suppressing the fire. }\end{array}$ \\
\hline Unplanned ignition & $\begin{array}{l}\text { Natural fire that is permitted to burn under specific conditions, in certain } \\
\text { locations, to achieve defined resource objectives. }\end{array}$ \\
\hline $\begin{array}{l}\text { Wildland Fire Management } \\
\text { (WFMP) }\end{array}$ & $\begin{array}{l}\text { Full range of activities and functions needed for planning, preparedness, } \\
\text { emergency suppression operations, emergency rehabilitation, and } \\
\text { prescribed fire operations. Includes managing non-activity fuels to } \\
\text { reduce risks to public safety and to restore and sustain ecosystem } \\
\text { health. }\end{array}$ \\
\hline $\begin{array}{l}\text { Wildland Fire Situation Analysis } \\
\text { WFSA) }\end{array}$ & $\begin{array}{l}\text { Decision-making process that evaluates management strategies against } \\
\text { selected safety, environmental, social, economical, political, and } \\
\text { resource management objectives as selected criteria. }\end{array}$ \\
\hline Wilderness & $\begin{array}{l}\text { Area established by the federal government and administered by } \\
\text { agencies in order to conserve its primeval character and influence for } \\
\text { public enjoyment, under primitive conditions, in perpetuity. }\end{array}$ \\
\hline Wildfire & Unwanted wildland fire. \\
\hline Wildland & Undeveloped land, not necessarily a designated "wilderness." \\
\hline Wildland fire & Any non-structured fire, other than prescribed fire, occurring in wildland. \\
\hline Wildland-urban interface fire & A wildland fire that threatens or involves structures. \\
\hline
\end{tabular}




\section{Appendix B:}

\section{Delegation of Authority - Extended Attack}

\section{Appendix B: Delegation of Authority}

Name of Incident Commander is assigned as Incident Commander of the Name of Incident, for Brookhaven National Laboratory (BNL) effective Time and Date.

The Incident Commander has full authority and responsibility for managing the fire suppression activities within the framework of the law and BNL policy and direction as provided by this office. The Resource Advisor will provide habitat Management Plans and other appropriate documents.

Names of Resources Advisors and contact Information are assigned as Resource Advisors. They or the Area Manager will be consulted in situations where natural resource decisions or trade offs are involved unless life safety issues require immediate attention and those actions will be documented.

Specific direction and fire suppression priorities for the Name of Incident are as follows, and are in priority order:

1. Provide for firefighter and public safety.

2. Use of minimal impact techniques should be employed to reduce habitat damage. Use natural barriers, fuel breaks, and roads if possible for burnout operations.

3. Use of dozers or tractors requires approval of the Area manager or their designate (resource advisors) prior to implementation. Include other Standards or conditions as needed.

\section{Turn-Back Standards}

1. All Name of Incident contracts, agreements, bills, medical problems, equipment repairs, and fire cache re-supply shall be closed out prior to team being released.

2. Road damage during suppression efforts will be repaired prior to the teams departure.

3. Fire perimeter mopped-up Specify and all lines checked for heat and integrity.

4. Rehabilitation Plan will be completed in Coordination with the BNL Resource Advisors.

5. Fire perimeter mapped by GPS and loaded into the GIS Database.

6. Tort claims reviewed by Area Manager or their designee.

The Deputy Area Manager will represent the Area Manager on any occasion where Manager is not immediately available.

Area Manager, Brookhaven National Laboratory

Date and Time, 
This page intentionally blank. 


\title{
Appendix C: Sample - Prescribed Fire Plan
}

\author{
Current Plan to be inserted as sample
}




\title{
PRESCRIBED FIRE PLAN
}

\author{
ADMINISTRATIVEUNIT(S): Brookhaven National Lab (BNL) \\ PRESCRIBED FIRE NAME: $\quad$ Brookhaven National Lab Northeast Units

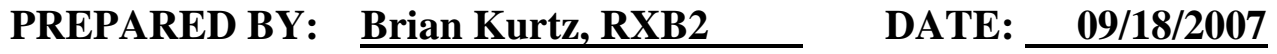 \\ The Nature Conservancy Reviewed:_09/23/2008 \\ TECHNICAL REVIEW BY: Bryan Gallagher___ DATE: \\ NYSDEC
}

NATURAL RESOURCE REVIEW BY: Tim Green DATE: $\underline{\text { 09/28/2009 }}$

BNL FIRE REVIEW BY: $\quad$ Charles LaSalla $\quad$ DATE: $\underline{10 / 05 / 2009}$

EMERGENCY PLANNING

REVIEW BY: $\quad$ Michael Pena $\quad$ DATE: $\underline{10 / 05 / 2009}$

DOE REVIEW BY: __ Gerald Granzen___ DATE: _ _ 10/09/2009

COMPLEXITY RATING: LOW

APPROVED BY: __ Michael Holland___ DATE:_ 10 _ _ _ _

Michael Holland, DOE-BHSO

APPROVED BY: ____ Mike Bebon__ DATE: $[\underline{10 / 09 / 2009}$

Michael Bebon, BNL

Plan Rewrite: October 2012 
This Page Intentionally Left Blank 
Unit Name: Brookhaven National Lab Northeast Units

\section{ELEMENT 2: AGENCY ADMINISTRATOR PRE-IGNITION APPROVAL CHECKLIST - BNL \& DOE ADMINISTRATORS}

Instructions: The Agency Administrator's Pre-Ignition Approval is the intermediate planning review process (i.e. between the Prescribed Fire Complexity Rating System Guide and Go/No-Go Checklist) that shall be completed before a prescribed fire can be implemented. For the purposes of BNL, the agency administrator is Michael Holland for the Department of Energy and Michael Bebon for the Laboratory. The Agency Administrator's Pre-Ignition Approval evaluates whether compliance requirements, Prescribed Fire Plan elements, and internal and external notifications have been or will be completed and expresses the Agency Administrator's intent to implement the Prescribed Fire Plan. If ignition of the prescribed fire is not initiated prior to expiration date determined by the Agency Administrator, a new approval will be required.

\begin{tabular}{|c|c|c|}
\hline YES & NO & KEY ELEMENT QUESTIONS \\
\hline $\mathbf{X}$ & & $\begin{array}{l}\text { Is the Prescribed Fire Plan up to date? } \\
\text { Hints: amendments, seasonality. }\end{array}$ \\
\hline $\mathbf{X}$ & & $\begin{array}{l}\text { Will all compliance requirements be completed? } \\
\text { Hints: cultural, threatened and endangered species, smoke management, NEPA. }\end{array}$ \\
\hline $\mathbf{X}$ & & $\begin{array}{l}\text { Is risk management in place and the residual risk acceptable? } \\
\text { Hints: Prescribed Fire Complexity Rating Guide completed with rational and mitigation measures identified } \\
\text { and documented? }\end{array}$ \\
\hline $\mathbf{X}$ & & $\begin{array}{l}\text { Will all elements of the Prescribed Fire Plan be met? } \\
\text { Hints: Preparation work, mitigation, weather, organization, prescription, contingency resources }\end{array}$ \\
\hline $\mathbf{X}$ & & $\begin{array}{l}\text { Will all internal and external notifications and media releases be completed? } \\
\text { Hints: Preparedness level restrictions }\end{array}$ \\
\hline \multirow[t]{2}{*}{$\mathbf{X}$} & & Will key agency staff be fully briefed and understand prescribed fire implementation? \\
\hline & $\mathrm{X}$ & $\begin{array}{l}\text { Are there any other extenuating circumstances that would preclude the successful implementation of the } \\
\text { plan? }\end{array}$ \\
\hline $\mathbf{X}$ & & $\begin{array}{l}\text { Have you determined if and when you are to be notified that contingency actions are being taken? Will this } \\
\text { be communicated to the Burn Boss? }\end{array}$ \\
\hline & & Other: \\
\hline
\end{tabular}

Recommended by: __ Brian Kurtz

Date: _9/18/2007

Prescribed Fire Burn Boss Type II

Approved by: Michael Holland Date: $\_10 / 09 / 2009$

Michael Holland, DOE-BHSO

Approved by: Mike Bebon Date: $\_\underline{10 / 09 / 2009}$

Michael Bebon, BNL

Approval expires (date): $10 / 08 / 2010$ 
Administrative Unit: BROOKHAVEN NATIONAL LABORATORY

Unit Name: Brookhaven National Lab Northeast Units

This Page Intentionally Left Blank 


\section{ELEMENT 2: PRESCRIBED FIRE GO/NO-GO CHECKLIST}

A. Has the burn unit experienced unusual drought conditions or contain above YES

NO normal fuel loadings which were not considered in the prescription development?

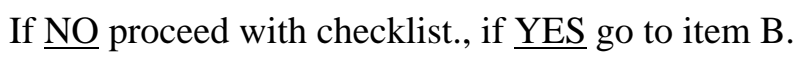

B. If $\underline{\text { YES }}$ have appropriate changes been made to the Ignition and Holding plan

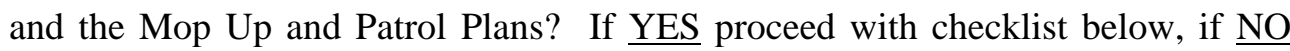
STOP.

\begin{tabular}{|l|l|l|}
\hline YES & NO & \\
\hline & & QUESTIONS \\
\hline & & $\begin{array}{l}\text { Are ALL fire prescription elements met? } \\
\text { Has ALL required current and projected fire weather forecast been obtained and are they } \\
\text { favorable? }\end{array}$ \\
\hline & & $\begin{array}{l}\text { Are ALL planned operations personnel and equipment on-site, available, and operational? } \\
\text { Has the availability of ALL contingency resources been checked, and are they available? }\end{array}$ \\
\hline & $\begin{array}{l}\text { Have ALL personnel been briefed on the project objectives, their assignment, safety } \\
\text { hazards, escape routes, and safety zones? }\end{array}$ \\
\hline & $\begin{array}{l}\text { Have all the pre-burn considerations identified in the Prescribed Fire Plan been completed } \\
\text { or addressed? }\end{array}$ \\
\hline Have ALL the required notifications been made? \\
\hline Are ALL permits and clearances obtained? \\
\hline it meet the planned objective?
\end{tabular}

If all the questions were answered "YES" proceed with a test fire. Document the current conditions, location, and results

Burn Boss

DOE Representative
Date

\begin{tabular}{ll}
\hline \multicolumn{2}{c}{ Date } \\
\hline BNL Representative
\end{tabular}


Administrative Unit: BROOKHAVEN NATIONAL LABORATORY

Unit Name: Brookhaven National Lab Northeast Units

This Page Intentionally Left Blank 


\section{ELEMENT 3 COMPLEXITY ANALYSIS SUMMARY}

\begin{tabular}{|c|c|c|c|}
\hline ELEMENT & RISK & $\begin{array}{c}\text { POTENTIAL } \\
\text { CONSEQUENCE }\end{array}$ & $\begin{array}{l}\text { TECHNICAL } \\
\text { DIFFICULTY }\end{array}$ \\
\hline 1. Potential for escape & $\mathrm{L}$ & M & $\mathrm{L}$ \\
\hline $\begin{array}{l}\text { 2. The number and dependence of } \\
\text { activities }\end{array}$ & $\mathrm{L}$ & $\mathrm{L}$ & $\mathrm{L}$ \\
\hline 3. Off-site Values & $\mathrm{L}$ & M & $\mathrm{L}$ \\
\hline 4 On-Site Values & $\mathrm{L}$ & $\mathrm{L}$ & $\mathrm{L}$ \\
\hline 5. Fire Behavior & $\mathrm{L}$ & M & $\mathrm{L}$ \\
\hline 6. Management organization & $\mathrm{L}$ & $\mathrm{L}$ & $\mathrm{L}$ \\
\hline 7. Public and political interest & $\mathrm{M}$ & $\mathrm{M}$ & $\mathrm{L}$ \\
\hline 8. Fire Treatment objectives & $\mathrm{L}$ & $\mathrm{L}$ & $\mathrm{L}$ \\
\hline 9 Constraints & $\mathrm{L}$ & $\mathrm{L}$ & $\mathrm{L}$ \\
\hline 10 Safety & $\mathrm{L}$ & $\mathrm{M}$ & $\mathrm{L}$ \\
\hline 11. Ignition procedures/ methods & $\mathrm{L}$ & $\mathrm{L}$ & $\mathrm{L}$ \\
\hline 12. Interagency coordination & $\mathrm{L}$ & $\mathrm{L}$ & $\mathrm{M}$ \\
\hline 13. Project logistics & $\mathrm{L}$ & $\mathrm{L}$ & $\mathrm{L}$ \\
\hline 14 Smoke management & $\mathrm{L}$ & $\mathrm{M}$ & $\mathrm{L}$ \\
\hline
\end{tabular}




\begin{tabular}{|l|l|}
\hline COMPLEXITY RATING SUMMARY \\
\hline RISK & \multicolumn{1}{|c|}{ OVERALL RATING } \\
\hline CONSEQUENCES & \multicolumn{1}{|c|}{ LOW / MODERATE } \\
\hline TECHNICAL DIFFICULTY & \multicolumn{1}{c|}{ LOW } \\
\hline SUMMARY COMPLEXITY DETERMINATION & $\begin{array}{l}\text { LOW } \\
\text { RATIONALE: The proposed action requires standard burn methods, coordination, safety mitigation and } \\
\text { sommunication. BNL has a community of private residences to the north and infrastructure to the west and } \\
\text { intended unit has the potential for containment prior to impacting these values. Contingency planning } \\
\text { addresses these potential consequences with staffing for at least one engine or brush truck by the BNL fire } \\
\text { department, as well as the ability to receive mutual aid resources provided by local volunteer fire } \\
\text { departments (Ridge and Manorville). The safety and risk factors are mitigated by low fuel loading / fuel } \\
\text { bed depth and wide roads surrounding unit. }\end{array}$
\end{tabular}


Administrative Unit: BROOKHAVEN NATIONAL LABORATORY

Unit Name: Brookhaven National Lab Northeast Units

\section{ELEMENT 4: DESCRIPTION OF PRESCRIBED FIRE AREA}

\section{A. Physical Description}

1. Location: Brookhaven National Laboratory

Brookhaven National Laboratory ("BNL") is located in Upton, Town of Brookhaven, County of Suffolk, New York. BNL is a federal facility owned by the Department of Energy. The Northeast Units are located in the northeastern corner of BNL, immediately west of East Firebreak Road.

Legal Description: Lat. 40 52' 56.18" N ～Long. 72 50' 59.67" W

2. Size: Northeast Units: 58.4 acres

3. Topography: Northeast Units: flat

4. Project Boundary: The prescribed fire blocks are rectangular in shape and are surrounded by woods roads and firebreaks 20 - 80 feet wide on all four sides. Fire vehicles can access all sides of the unit. The Northeast Units is divided into 4 subunits, each approximately 15 acres in size.

\section{B. Vegetation/Fuels Description:}

1. On-site fuels data:

The 58.4 acre unit consists of hardwood forest with a canopy height of from 40 to $60 \mathrm{ft}$. Overstory species at the site include red oak (Quercus rubra), black oak (Quercus velotina) and pitch pine (Pinus rigida). The average percent density of overstory trees throughout the entire burn unit consists of $37 \%$ live oaks, $42 \%$ dead oaks, $19 \%$ live pines, and $2 \%$ dead pine. The dominant overstory species varies per stand in each subunit (see charts below). 
Administrative Unit: BROOKHAVEN NATIONAL LABORATORY

Unit Name: Brookhaven National Lab Northeast Units

\begin{tabular}{|c|c|l|c|c|}
\hline Sub Unit & Stand & Species & \% Density & BA \\
\hline A & 1 & Oak - live & 3 & 5 \\
\hline & & Oak - dead & 74 & 50 \\
\hline & & Pine - live & 23 & 73 \\
\hline
\end{tabular}

\begin{tabular}{|c|c|l|c|c|}
\hline Sub Unit & Stand & Species & \% Density & BA \\
\hline A & 2 & Oak - live & 29 & 45 \\
\hline & & Oak - dead & 58 & 25 \\
\hline & & Pine - live & 13 & 20 \\
\hline
\end{tabular}

\begin{tabular}{|c|c|l|c|c|}
\hline Sub Unit & Stand & Species & \% Density & BA \\
\hline B & 3 & Oak - live & 45 & 58 \\
\hline & & Oak - dead & 45 & 36 \\
\hline & & Pine - live & 10 & 28 \\
\hline
\end{tabular}

\begin{tabular}{|c|c|l|c|c|}
\hline Sub Unit & Stand & Species & \% Density & BA \\
\hline C & 4 & Oak - live & 45 & 36 \\
\hline & & Oak - dead & 38 & 30 \\
\hline & & Pine - live & 17 & 50 \\
\hline
\end{tabular}

Note: BA = basal area of tree (the cross sectional area taken at 4.5 feet above ground level) 
Administrative Unit: BROOKHAVEN NATIONAL LABORATORY

Unit Name: Brookhaven National Lab Northeast Units

\begin{tabular}{|c|c|l|c|c|}
\hline Sub Unit & Stand & Species & \% Density & BA \\
\hline C & 5 & Oak - live & 40 & 54 \\
\hline & & Oak - dead & 51 & 25 \\
\hline & & Pine - live & 4 & 8 \\
\hline & & Pine - dead & 5 & 13 \\
\hline
\end{tabular}

\begin{tabular}{|c|c|l|c|c|}
\hline Sub Unit & Stand & Species & \% Density & BA \\
\hline D & 6 & Oak - live & 69 & 55 \\
\hline & & Oak - dead & 13 & 8 \\
\hline & & Pine - live & 11 & 23 \\
\hline & & Pine - dead & 7 & 5 \\
\hline
\end{tabular}

\begin{tabular}{|c|c|l|c|c|}
\hline Sub Unit & Stand & Species & \% Density & BA \\
\hline D & 7 & Oak - live & 27 & 20 \\
\hline & & Oak - dead & 20 & 7 \\
\hline & & Pine - live & 53 & 63 \\
\hline
\end{tabular}

These stands have been affected in the recent past by multiple defoliations by the orange striped oakworm and other insect defoliators, resulting in the high number of dead standing oak snags in the project area (see above).

The understory is dominated by blueberry species (Vaccinium spp.), black huckleberry (Gaylussacia baccata) and to a lesser extent by black oak (Quercus velutina). It is moderate in density and averages 25,529 stems per acre (huckleberry/blueberry). The understory layer ranges from 0.1 to 2 feet in height (avg. 1.6 feet). Slash depth ranged from 0.1 to 6.5 feet (avg. 8.5 inches). Leaf litter depth ranges from 1 to 8 inches (avg. 3 inches). The principal fuels of the forest stands at the burn site will be the leaf litter, portions of the woody understory, and downed woody material. Average weighted fuel bed depth for this unit is $0.41 \mathrm{ft}$. A custom fuel model has been developed for these units based on down woody fuel transects and harvest plots. The southern most 8.6 acres of subunit A, was burned through the 
Administrative Unit: BROOKHAVEN NATIONAL LABORATORY

Unit Name: Brookhaven National Lab Northeast Units

use of prescribed fire in October 2006.

2. Adjacent fuels data: Fuels outside the unit are similar in structure and composition to the fuels inside the project area. Overstory fuels east of the firebreak become more dominated by pitch pine and pine needle litter than inside the unit.

\section{Description of Unique Features:}

The prescribed fire area is adjacent to an area fenced in to protect a former scientific study site active between 1961 and 1978. This enclosure is just west of the prescribed fire unit on the west side of Old Margin Path (fire break). Inside the enclosure are historical trenching grounds most recently used by the military during World War I and the inner fence and abandoned structures of the scientific study. The East Firebreak Road, as well as the North Firebreak Road, are also the right-of-way for high tension power lines (138 kV and 69kV).

The lack of fire over the last 75 years, has led to a reduction in suitable habitat conditions for a variety of wildlife. The subunit is currently utilized by white-tailed deer and eastern wild turkey. The habitat potentially could be utilized by whippoorwill and other migratory songbirds. No threatened or endangered species are known to exist in the unit. 
Administrative Unit: BROOKHAVEN NATIONAL LABORATORY

Unit Name: Brookhaven National Lab Northeast Units

\section{ELEMENT 5: GOALS AND OBJECTIVES}

\section{A. Goals:}

Maintain a buffer along eastern and northern portions of the lab where hazardous fuels are reduced while the role of fire is restored in maintaining oak-pine and pine-oak forests.

1. Provide for firefighter and public safety (in the event of wildfire) through the reduction of hazardous fuels.

2. Minimize smoke impacts during wildfire events, by conducting prescribed fires when conditions allow for better lift, direction and dispersal, thereby minimizing impacts to sensitive receptors. Gain additional information on smoke behavior in this region of the Central Pine Barrens.

3. Improve conditions that will increase the probability of oak seedling germination and success.

4. Demonstrate differences in seasonality of treatments for both fire behavior and fire effects to enhance effectiveness of future prescribed fire actions.

5. Gain information regarding fire behavior within the treatment unit.

6. Provide training opportunities to enhance the experience of regional interagency prescribed fire and wildfire suppression crews.

\section{B. Objectives:}

1. Reduce existing litter, i.e. 1 and 10 hour fuels, by $30-90 \%$.

2. Top kill 30 - 90\% of the shrub component of the understory.

3. Expose $2-30 \%$ of bare mineral soil sites over the unit area

4. Monitor and record smoke and fire behavior for future local reference.

5. Provide experience for crew members in ignitions and holding operations and trainee roles. 
Administrative Unit: BROOKHAVEN NATIONAL LABORATORY

Unit Name: Brookhaven National Lab Northeast Units

\section{ELEMENT 6: FUNDING:}

A. Cost: Contribution of equipment and expendables by partner agencies.

B. Funding source: The burn will be conducted utilizing a combination of cooperating agencies including, but not limited to, New York Wildfire and Incident Management Academy, The Nature Conservancy, New York State Department of Environmental Conservation, as well as the US Fish \& Wildlife Service. Each respective cooperating agency will cover the costs of their personnel and use of their equipment. 
Administrative Unit: BROOKHAVEN NATIONAL LABORATORY

Unit Name: Brookhaven National Lab Northeast Units

\section{ELEMENT 7: PRESCRIPTION}

\section{A. Environmental Prescription:}

\begin{tabular}{||l|l|l||}
\hline Characteristic & Lower Value & Upper Value \\
\hline \hline Wind Direction & & \\
\hline Wind Speed (Midflame) & NE, N, W, S, SE & Restricted East \\
\hline Wind Gusts & $0 \mathrm{mph}$ & $10 \mathrm{mph}$ \\
\hline Temperature & $0 \mathrm{mph}$ & $15 \mathrm{mph}$ \\
\hline Relative Humidity & 30 & 95 \\
\hline 1- Hour Fuel Moisture & $25 \%$ & $70 \%$ \\
\hline Mixing Height & $6 \%$ & $18 \%$ \\
\hline
\end{tabular}

\section{B. Fire Behavior Prescription:}

\begin{tabular}{||l|l|l|l||l|}
\hline \hline CHARACTERISTIC & $\begin{array}{l}\text { Head Fire } \\
\text { Growing } \\
\text { Season }\end{array}$ & $\begin{array}{l}\text { Backing Fire } \\
\text { Growing } \\
\text { Season }\end{array}$ & $\begin{array}{l}\text { Head Fire } \\
\text { Dormant } \\
\text { Season }\end{array}$ & $\begin{array}{l}\text { Backing Fire } \\
\text { Dormant } \\
\text { Season }\end{array}$ \\
\hline \hline
\end{tabular}

FUEL MODEL: Custom FM based on dwf transects, harvest plots, and SO tally @ 6\% 1hr, 7\% 10hr

\begin{tabular}{||l|c|c|c||c||}
\hline Rate of Spread (chains/hr) & $2.8-22.3$ & $0.4-0.5$ & $3.6-28.1$ & $0.5-0.6$ \\
\hline Flame Length (ft) & $2.7-7.1$ & $1.1-1.2$ & $3.1-7.9$ & 1.3 \\
\hline
\end{tabular}


Administrative Unit: BROOKHAVEN NATIONAL LABORATORY

Unit Name: Brookhaven National Lab Northeast Units

\section{ELEMENT 8: SCHEDULING}

\section{A. Ignition Time Frames/Season(s):}

\begin{tabular}{||l|l|}
\hline Burn Dates & January $1-$ December 31 \\
\hline Time of Day & $0900-2000$ hrs (see constraint below) \\
\hline
\end{tabular}

B. Projected Duration: The prescribed fire treatment is not expected to last more than one operational period (typically a workday - nominally up to 12 hours). The 60 acre prescribed fire area is broken into four $\sim 15$ acre subunits. In general no more than one subunit may be burn in one operational period. Partial or incompletely burned subunits may be added to the next prescribed burn, so long as the unburned portion is less than $50 \%$ of the subunit. The maximum size of a prescribed burn during one operational period is 22 acres.

C. Constraints: Smoke must be directed away from highways and residences; rise sufficiently and disperse to avoid impacts to surrounding areas, including laboratory areas. No prescribed fire will take place if any impairment to BNL's water distribution system exists that would prevent operation of the nearest fire hydrants. No ignition activities will be conducted which would start 30 minutes prior to sunset. 
Administrative Unit: BROOKHAVEN NATIONAL LABORATORY

Unit Name: Brookhaven National Lab Northeast Units

\section{ELEMENT 9: PRE-BURN CONSIDERATIONS}

\section{A. Considerations:}

1. On Site: Permits and notifications, internal line construction to separate subunits, consideration of specific snags to be felled or protected, special features to be protected, weather recording, monitoring. Smoke may be visible from nearby buildings. Notify Laboratory personnel.

2. Off Site: Smoke may be visible from adjacent residences. Neighbor notification.

\section{B. Method and Frequency for Obtaining Weather and Smoke Management Forecast(s):}

The National Weather Service (NWS) Fire Weather Forecast (Upton Office) will be monitored prior to the burn. The fire weather forecast is prepared and issued daily by the local National Weather Service Forecast Office. On the day of the burn, a Spot Weather Forecast will be obtained from the local NWS Office through an agreement with the NWS Fire Weather Focal Point. The NWSFO-Upton and Fire Weather Focal Point or Public Forecaster can be reached at 1-631-924-0383 or 1-800-226-0217.

The onsite fire weather will be monitored by a crew member.

C. Notifications: Record notifications on contact list (attached).

A press release will be issued a minimum of 1 time per year to local newspapers to alert the public and interested parties to the upcoming prescribed burn seasons at BNL.

Notifications will be the responsibility of BNL's Natural Resource Manager in conjunction with CEGPA. 
Administrative Unit: BROOKHAVEN NATIONAL LABORATORY

Unit Name: Brookhaven National Lab Northeast Units

\section{ELEMENT 10: BRIEFING}

\section{Briefing Checklist:}

$\square$ Burn Organization

$\square$ Burn Objectives

$\square$ Description of Burn Area

$\square$ Expected Weather \& Fire Behavior

$\square$ Communications

$\square$ Ignition plan

$\square$ Holding Plan

$\square$ Contingency Plan

$\square$ Wildfire Conversion

$\square$ Safety 
Administrative Unit: BROOKHAVEN NATIONAL LABORATORY

Unit Name: Brookhaven National Lab Northeast Units

\section{ELEMENT 11: ORGANIZATION AND EQUIPMENT}

A. Positions: The following is the minimum staffing requirements to implement the prescribed burn. Additional resources may be used as available and assigned positions by the Burn Boss.

A single Burn Boss will oversee the project (RxB2). Two squad bosses will be required to supervise the divisions (FFT1). An additional 7 basic firefighters (FFT2) can fill other positions on the fireline. A minimum of ten personnel total, including the safety officer, will be involved with any prescribed burn.

All personnel will have as a minimum in training the fire courses S130/S190 (or equivalent) and physical requirements will include a score of "arduous" (or equivalent) for the pack test for hand crews and a score of "moderate" (or equivalent) via the field test for members of engine crews. (Note: State Agencies have similar requirements for qualifications that are considered appropriate for fire management and prescribed fire.) Personnel may include ( but are not limited to) staff from the U.S. Fish \& Wildlife Service, National Park Service, New York State Department of Environmental Conservation, U.S. Department of Agriculture, New York State Parks, The Nature Conservancy, BNL Fire Rescue Group, local volunteer firefighters and other qualified individuals.

Organization will be as follows:

Burn Boss - will coordinate and direct the activities during the burn.

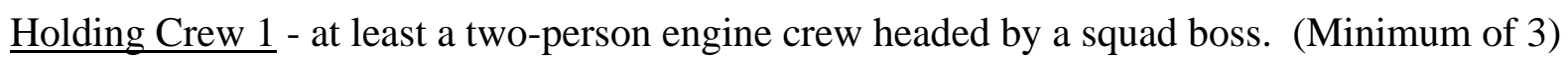

Holding Crew 2 - at least a two-person engine crew headed by a squad boss. (Minimum of 3)

Igniters - Minimum of 2

Smoke/Weather Observer - one or more individuals stationed downwind of the fire on alert for spotting or smoke behavior. This lookout may also serve as weather monitor. Minimum 1

Safety Officer- this individual is responsible for monitoring the safety operations of and around 
Administrative Unit: BROOKHAVEN NATIONAL LABORATORY

Unit Name: Brookhaven National Lab Northeast Units

the fire, and the perimeter area to ensure that unauthorized access does not occur. The Safety Officer monitors fire operations to ensure all workers are conducting operations in a safe manner and to identify safety issues prior to ignition for mitigation and/or avoidance. If 'normal' operational safety concerns are identified, this individual notifies the Burn Boss (as warranted) of conditions to determine necessity for shutting down operations. In the event of a concern that is immediately dangerous to life and health, the safety officer may direct the shutdown. This position will be filled with a BNL or DOE representative and does not require fireline qualifications.

\section{B. Equipment:}

A minimum of one Type 6 engine.

A minimum of one additional engine consisting of a Type 4, 5, 6, or 7.

A minimum of 4 drip torches.

Equipment will be provided and used as determined by the burn boss and made available through the caches of cooperating agencies. Equipment typically includes (but is not limited to) backpack pumps, council rakes, chain saws, wildland engines, drip torches, etc. Each individual on the fire line shall have proper PPE including Nomex Clothing, hard hat, leather boots, eye and ear protection, and fire shelter.

\section{Supplies}

20-30 gallons of drip torch fuel.

Drinking water.

\section{Training Burn:}

A small portion of a unit may be burned as part of a live fire training exercise. If the active fire area is less than one acre in size and anchored to roads or previously burned areas fewer crew and equipment will be required. A training exercise may be conducted with one RxB2, one squad boss, and a minimum of 4 additional personnel. One engine and a backup portable pump will be required. Additional engines may take the place of the portable pump. Ecological and 
Administrative Unit: BROOKHAVEN NATIONAL LABORATORY

Unit Name: Brookhaven National Lab Northeast Units

fuel management objectives may not be met during a training burn. Note that training burns can be conducted on the "cool side" of the prescription (low winds, high RH, high 1hr fuel moisture) as they are small in nature and primarily for demonstration purposes.

No ecological harm occurs from low intensity prescribed fire which provides optimal conditions for training individuals in basic wildland/prescribed fire techniques. 


\section{ELEMENT 12: COMMUNICATION}

\section{A. Radio Frequencies}

At least one radio will be distributed to the burn boss, each holding crew, lookout/smoke spotter and the lead igniter. Radios will also be distributed to each engine. A cellular phone will be on site with the burn boss, smoke spotter and one will be with each squad. Clear text will be used in all communications. Specific communication plans and frequencies will be discussed during briefing and agreed upon by cooperating agencies prior to implementation.

1. Command Frequency(s): to be determined onsite and radio reception verified

2. Tactical Frequency(s): to be determined onsite and radio reception verified

3. Air Operations Frequency(s): to be determined, as needed

Telephone Numbers:

BNL Fire Department EMERGENCY: 631-344-2222

BNL Fire-Rescue Duty Captain: 631-344-2351

Tim Green (cell): 631-872-8794

Michael Pena, Emergency Management

(cell): 631-879-2031

Cellular service and radio transmissions will be verified prior to ignition. 


\section{ELEMENT 13: PUBLIC AND PERSONNEL SAFETY, MEDICAL}

Safety Hazards: Fire behavior, smoke impacts to fireline personnel, tripping, dehydration and fatigue (especially in summer months), significant number of snags inside the unit, pockets of catbrier outside unit, tick borne illness, ground nesting bees.

Measures Taken to Reduce the Hazards: Each individual on the fire line shall have proper PPE including Nomex Clothing, hard hat, leather boots, eye and ear protection, and fire shelter.

Observers shall have Nomex Clothes, hard hat, full foot cover foot protection (no opentoed shoes), and eye protection.

Personnel being exposed to smoke should be rotated into positions where the smoke is less (based upon fire behavior and their operational position).

Dehydration and fatigue will be discussed with the firefighters at the crew briefing on burn day. It will be the responsibility of squad bosses to monitor personnel.

Snags along the perimeter of the firebreaks will be assessed and felled as necessary before the burn.

Equipment will be provided and used as determined by the burn boss and made available through the caches of cooperating agencies. Equipment typically includes (but is not limited to) shovels, pulaskis, swatters, council rakes, chain saws, wildland engines, drip torches, backpack pumps, etc.

Personnel will be aware of tick and bee presence and avoid areas of high activity. Personnel will check themselves post fire to remove ticks within a 24 hour time period.

Hazards and safety issues will be part of the crew briefing to discuss any issues with the on-site team members.

Emergency Medical Procedures: Minor injuries will be handled at the scene. At least one First Aid trained crew member with proper equipment will be on scene. 
Unit Name: Brookhaven National Lab Northeast Units

Major injuries - call 631-344-2222 from cell phone.

Emergency Evacuation Methods: BNL Fire Department will coordinate evacuation (in the event it is necessary). The unit is surrounded by 2-wheel drive dirt roads. There is a heli-spot at the lab if air evacuation is required.

\section{Emergency facilities:}

University Medical Center Stony Brook Emergency Room; 631-689-8333

The following are important contact numbers for emergency communication. :

Fire:

$\begin{array}{ll}\text { BNL Fire Department } & 344-2222 \\ \text { Suffolk County Dept of Fire, Rescue and Emerg. Services } & 924-5252 \\ \text { New York State DEC Forest Rangers } & 444-0291 \\ \text { USFWS Long Island NWR Complex - Office } & 286-0485 \\ \text { Manorville Fire Department } & 878-6614 / 874-3760 \\ & \\ \text { Brookhaven Town Fire Marshal } & 451-6262 \\ \text { Mastic Fire Department } & 281-2022 \\ \text { Ridge Fire Department } & 924-3256 / 924-4080\end{array}$

Medical: $\quad$ Suffolk County Fire Communication Center 924-5252

University Medical Center Stony Brook 689-8333

Emergency Room (Ext - 1)

Nearest Phone: Cellular phone on site To be assigned

Other: $\quad$ National Weather Service Forecast Office - Upton 924-0383

Long Island Railroad 588-0600

BNL Sewage Treatment Plant (just SW of the burn) 344-2982

\section{ALL EMERGENCY RESPONSE CAN BE REACHED THROUGH 911, THE ABOVE NUMBERS ARE DIRECT LINES}




\section{ELEMENT 14 TEST FIRE}

A. Planned location: A test fire will be ignited on the down wind side of the burn unit. If results of the test fire are satisfactory, ignition will continue anchored into the test fire. With prevailing northwest winds during the spring, the test fire would anchor into the southeastern most portion of the prescribed fire area that was burned in October 2006. If the burn is conducted during the summer, with prevailing southerly winds, the test fire would anchor off of North Firebreak Road or other internal control line.

\section{B. Test Fire Documentation:}

1. Weather conditions On-Site: Recorded by weather monitor prior to ignition.

2. Test Fire Results: Recorded by Burn Boss notes. 


\section{ELEMENT 15: IGNITION PLAN}

A. Firing Methods: The decision on how the units will be burned is at the discretion of the Prescribed Fire Burn Boss with consideration given to weather parameters, fire behavior and smoke behavior characteristics, control factors, and firefighter safety.

Ignition will be performed from the ground primarily by drip torch application. Firing patterns and directions may change depending on wind direction or other parameters. Pre-determined ground contacts (drop points) along portions of the burn unit will be used to help communicate the progress of ignition operations.

General ignition directions will work from the downwind side and progress into the predominant wind direction. Fire behavior will be manipulated using various ignition techniques.

B. Devices: The primary ignition source for the burn unit will be hand ignition by drip torch. Fusees and/or a Very pistol with ignition flares may be also used.

C. Techniques: Objectives will be to create a safe and secure black line along the downwind burn unit boundaries while adding fire to the interior portions of the unit. Backing, flanking, and strip fires may be utilized to achieve objectives. Fire behavior will be manipulated using various ignition techniques. Primary ignition patterns used may include backing, flanking, and strip-head fires. Dot, chevron and ring head fires may also be used to achieve desired intensity and rate of spread, depending upon conditions.

D. Sequences: Firing operations will begin on the downwind side of the unit along the control lines (see project map). Ignition along each division will create a 1030' wide black line working off the downwind burn unit boundaries. Burn Boss and interior igniters will coordinate with holding crews to ensure proper pace and intensity. 
Unit Name: Brookhaven National Lab Northeast Units

E. Patterns: All ignition team members will use good care and communication to ensure safety of all personnel around the burn unit. Strip and dot firing patterns utilizing the contour and prevailing winds may be used to create an even backing, flanking and/or strip head fire through the interior of the burn unit.

F. Ignition Staffing: Two igniters, FFT2 qualifications or higher, will be used during perimeter firing operations. Depending upon conditions, the Burn Boss may use additional igniters in the interior of the unit to achieve objectives. 


\section{ELEMENT 16: HOLDING PLAN}

General Procedures for Holding: Woods roads surrounding the burn unit will be used as burn unit boundaries for holding operations. Internal control lines constructed prior to ignition may be utilized for burning sub units.

Division supervisors (squad bosses) will be responsible for the holding crews and equipment throughout the burn. A minimum of one type 6 wildland engine, one additional type 4, 5, 6 or 7 wildland engine, or portable pumps and six backpack pumps will be available to assist in holding activities. A minimum of three people will be assigned to holding for each division with a minimum of two divisions required for the burn.

Natural and existing barriers (changes in vegetation, burned areas, and trails) will be utilized to contain fire within the burn unit. Division supervisors (squad bosses) may assign Squad Bosses for each division to maintain span of control, as necessary. The Prescribed Fire Burn Boss and Division supervisors shall work together to ensure that the ignition pattern and timing do not present any holding concerns on the burn and is coordinated with appropriate holding actions.

Beyond what the wildland engines can carry, the primary water source will be the fire hydrants, which are approximately 0.75 miles away from the burn unit. The secondary water sources may include portable ponds, additional engines and/or water tenders. Just east of First Street on Forest Path is an old concrete draft site. Here, only 0.5 miles from the burn unit, the Peconic River may be used as an additional water source.

All crew members should denote on the project map the divisions, drop points, access roads, water sources, staging areas and other information during the pre-fire briefing.

Critical Holding Points and Actions: Critical holding areas are outside any woods road being used as a firebreak, particularly the enclosed area to the west, which would have access problems associated with it. Concentrated efforts along these boundaries to minimize spread and impacts of any slop-over or spot fires will be taken.

Minimum Organization or Capabilities Needed: The holding crews will consist of a minimum of 2 squad bosses and 4 FFT2's (total). 


\section{ELEMENT 17: CONTINGENCY PLAN}

A. Trigger Points: If spot fires and/or slop-overs can not be contained with on-scene resources and/or immediately threaten private property, the Burn Boss will declare it a wildfire and contact the BNL Fire Department (631-344-2222) and NYSDEC for assistance.

B. Actions Needed: In the event of a significant spot fire or slop-over, the nearest resource will size up the fire and report size, location, fuels, fire behavior, and recommended tools and personnel needed for containment. Spot fires outside the burn perimeter within the capability of on-scene resources are considered within the prescription. Ignition of the prescribed fire will cease, if safely possible. Resources will be assigned to take appropriate suppression action on both the prescribed fire and wildfire until contingency resources arrive on scene.

If the fire is declared a wildfire, an incident command post (ICP) shall be set-up in a safe location. The BNL duty fire captain will establish a unified command with the burn boss.

C. Additional Resources and Maximum Response Time(s): If the fire exceeds the capability of the crews on hand and/or immediately threatens private property, a call will be placed for assistance from local resources through the BNL Fire Department. Typical response time for the BNL Fire Department to the outer portions of the site is within 8 minutes. The contingency plan will be reviewed in the crew briefing.

\section{STOP WORK AUTHORITY}

Any crew member, the Safety Officer, DOE representative, BSA Representative, or BNL Fire Chief shall have "stop work" authority. Anyone who notices safety issues that may threaten life, health or property has the authority to "stop work." They shall immediately notify either the Safety Officer or the Burn Boss, identify the safety concern, and request that work be stopped to address the concern appropriately.

If no fire has been ignited, the Burn Boss must terminate the burn in an orderly fashion. If ignition of the unit has begun, the Burn Boss will first take steps to contain the prescribed fire in a safe and effective manner. The Burn Boss may need to continue with and/or complete ignition in order to safely and effectively contain the prescribed fire in the shortest amount of time with the least impact to safety and resources. 


\section{ELEMENT 18: WILDFIRE CONVERSION}

A. Wildfire Declared By: Burn Boss

B. IC Assignment: Burn Boss will assume the role of Incident Commander until Unified Command is established or command is transferred to local fire chief.

C. Notifications: Immediate - BNL Fire Department to dispatch contingency resources. Secondary (if not present) - Tim Green, Natural Resources Manager at 631-872-8794 and Michael Pena, Emergency Management at 631-879-2031 (after contingency resources have been requested). Natural resources manager will notify Suffolk County Parks or other public landowners whose property may be threatened.

D. Extended Attack Actions and Opportunities to Aid in Fire Suppression: The Burn Boss will coordinate with the BNL fire chief, or designee, to establish a unified command structure and determine appropriate actions for available resources (personnel and equipment). The unified command may turn down resource assignments if safe and appropriate tactics are not utilized. 


\section{ELEMENT 19: SMOKE MANAGEMENT AND AIR QUALITY}

A. Compliance: The weather conditions will be monitored throughout the burning operational period, starting before the test fire is ignited. The smoke dispersal will be monitored through the burn; by the Burn Boss and other burn crew members.

B. Permits to be Obtained: A New York State Burn Permit is required for all prescribed burns in Suffolk County. Prescribed burn will not take place without an approved Burn Permit. A fully reviewed and approved Burn Plan by NYSDEC (technical review and signature) verifies that a New York State Burn Permit is approved.

\section{Smoke Sensitive Areas/Receptors:}

Special safety precautions needing attention include the Long Island Railroad tracks to the south of the burn area and the potential for smoke on roads and impacts to BNL facilities to the west and southwest.

The potential for smoke on roads will be addressed by the use of a spotter or observer. The spotter will be mobile and located downwind from the burn unit. Responsibilities will include monitoring roads and railroads, to ensure smoke is not impacting traffic and facilities/residences. If smoke begins to settle or drift at low altitude toward smokesensitive areas, rate of burning will be adjusted to ensure lift and dispersal, or burn will be shut down if safely possible. The smoke spotter will be equipped with a hand-held radio and cell phone and will report directly to the burn boss.

The closest sensitive areas to the burn site are included in the following table. Due to the small size of the burn area and short burn time, with the proper weather conditions, the smoke produced should dissipate in a short period of time. 


\section{Impacted Areas:}

\begin{tabular}{||l|c|c||}
\hline FEATURE & DIRECTION & DISTANCE (FT) \\
\hline \hline Long Island Railroad & & \\
\hline RHIC ring & South & 8,500 \\
\hline Ridge Housing & West & 5,280 \\
\hline Long Island Expressway & North & 5,000 \\
\hline
\end{tabular}

\section{E. Mitigation Strategies and Techniques to Reduce Smoke Impacts:}

\section{NECESSARY TRANSPORT WIND DIRECTION, SPEED AND MIXING HEIGHT.}

Desired smoke behavior is good lift and dispersal with low concentrations of smoke. With appropriate lofting conditions (unstable atmospheric conditions) any wind direction will be suitable to transport the smoke away from sensitive areas. A critical component for this burn to ensure adequate mixing and removal of smoke is unstable atmospheric conditions. A minimum mixing height of 1000 ' is suggested.

\section{VISIBILITY HAZARDS.}

If smoke poses a significant visibility hazard (visibility reduced to 0.25 mile or less) over any highway, road or railroad tracks then the fire ignition pattern will be adjusted, ignition suspended and/or the fire will be suppressed until weather conditions change

\section{ACTIONS TO REDUCE VISIBILITY HAZARDS}

A smoke/weather observer will be used in part to monitor smoke conditions. Signs will be posted, as necessary and appropriate, along roads and within communities on the downwind side of the burn that have the potential to be impacted by smoke. 
Administrative Unit: BROOKHAVEN NATIONAL LABORATORY

Unit Name: Brookhaven National Lab Northeast Units 


\section{ELEMENT 20: MONITORING}

A. Fuels Information (forecast and observed) Required Procedures: Fine dead fuel moisture may be calculated based on spot weather forecast data. The plan calls for fine dead fuel moisture levels between $6 \%$ and $18 \%$ inclusive in order to initiate the burn.

B. Weather Monitoring Required and Procedures: The morning of the burn, a spot weather forecast will be obtained from the National Weather Service in Upton. Prior to initiating the burn, wind direction, midflame wind speed, temperature and relative humidity data will be collected using a belt weather kit at the burn site.

C. Fire Behavior Monitoring Required and Procedures: During the test burn the Burn Boss will confirm appropriate fire behavior. The Burn Boss will communicate with the igniters during firing to monitor fire behavior.

\section{Monitoring Required To Ensure That Prescribed Fire Plan Objectives Are Met:} Pretreatment overstory stand and understory fuels data was collected on each of the subunits. Immediate post fire effects surveys within several days assist in documenting first order fire effects. The growing season after prescribed fire implementation is conducted, post treatment surveys should be conducted.

E. Smoke Dispersal Monitoring Required and Procedures: See smoke management section for additional details. 


\section{ELEMENT 21: POST-BURN ACTIVITIES}

Post-burn Activities That Must be Completed: Light rehabilitation of firelines between subunits may be warranted as determined by BNL's Natural Resource Supervisor. An After Action Review (AAR) will be conducted by the Burn Boss and crew. A post fire report may be used to summarize fire operations, conditions, and monitoring results. 


\title{
APPENDICES
}

\author{
A. Maps: Vicinity, Project, Hydrant, and Contingency \\ B. Technical Review Checklist \\ C. Complexity Analysis \\ D. Job Hazard Analysis \\ E. Fire Behavior Modeling Documentation or Empirical Documentation (unless it \\ is included in the fire behavior narrative in Element 7; Prescription)
}


1. Vicinity Map:

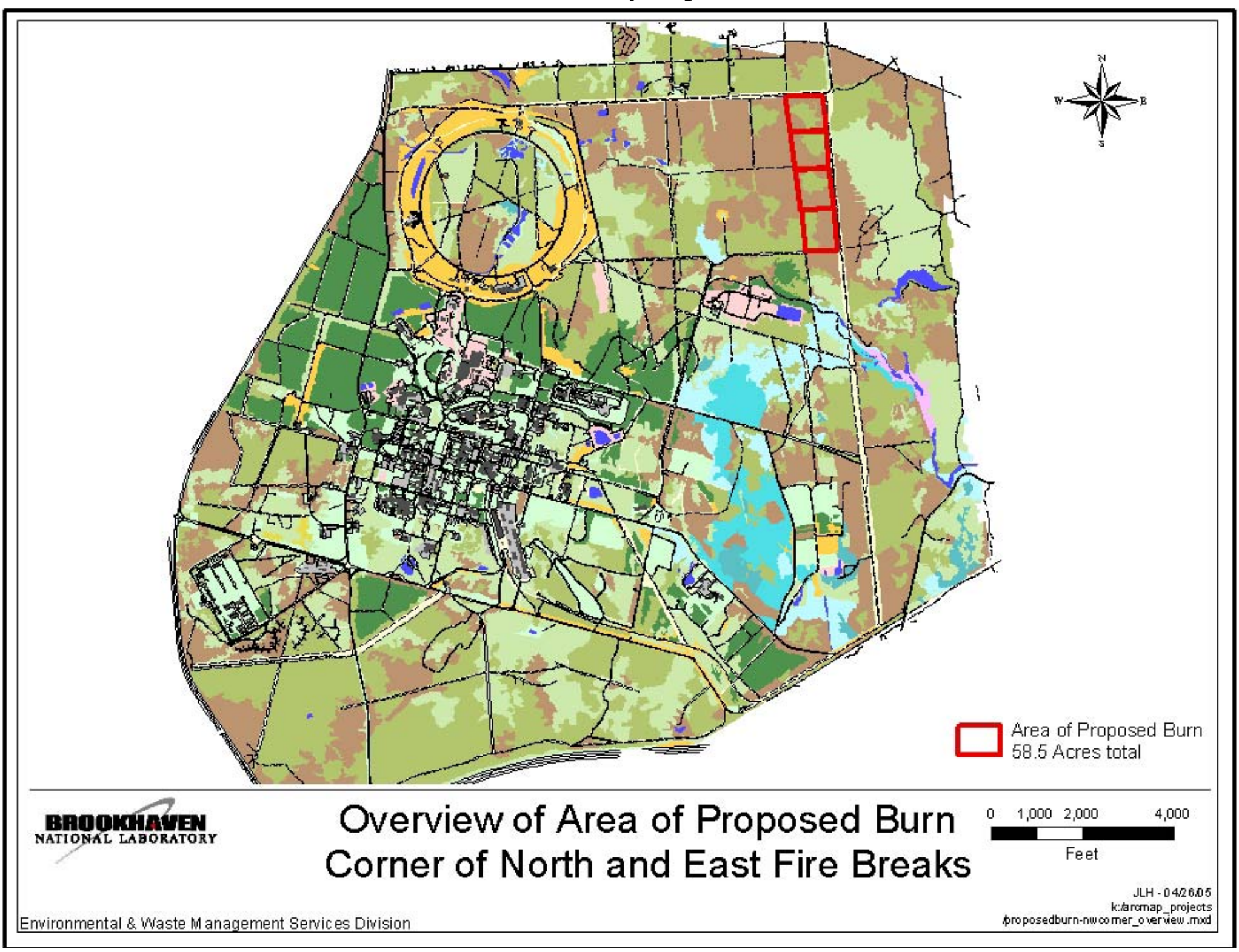


Unit Name: Brookhaven National Lab Northeast Units

\section{Project Map:}

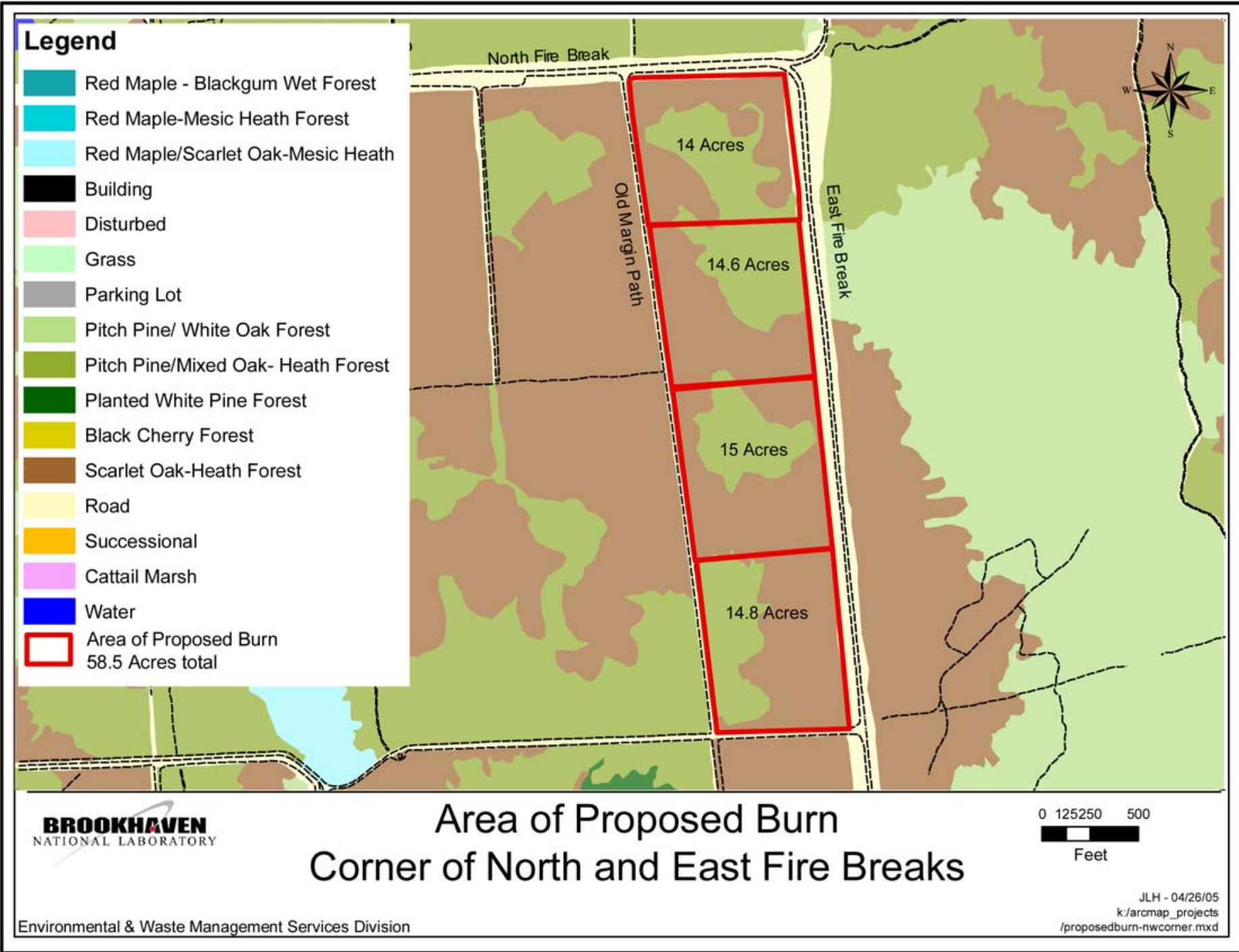




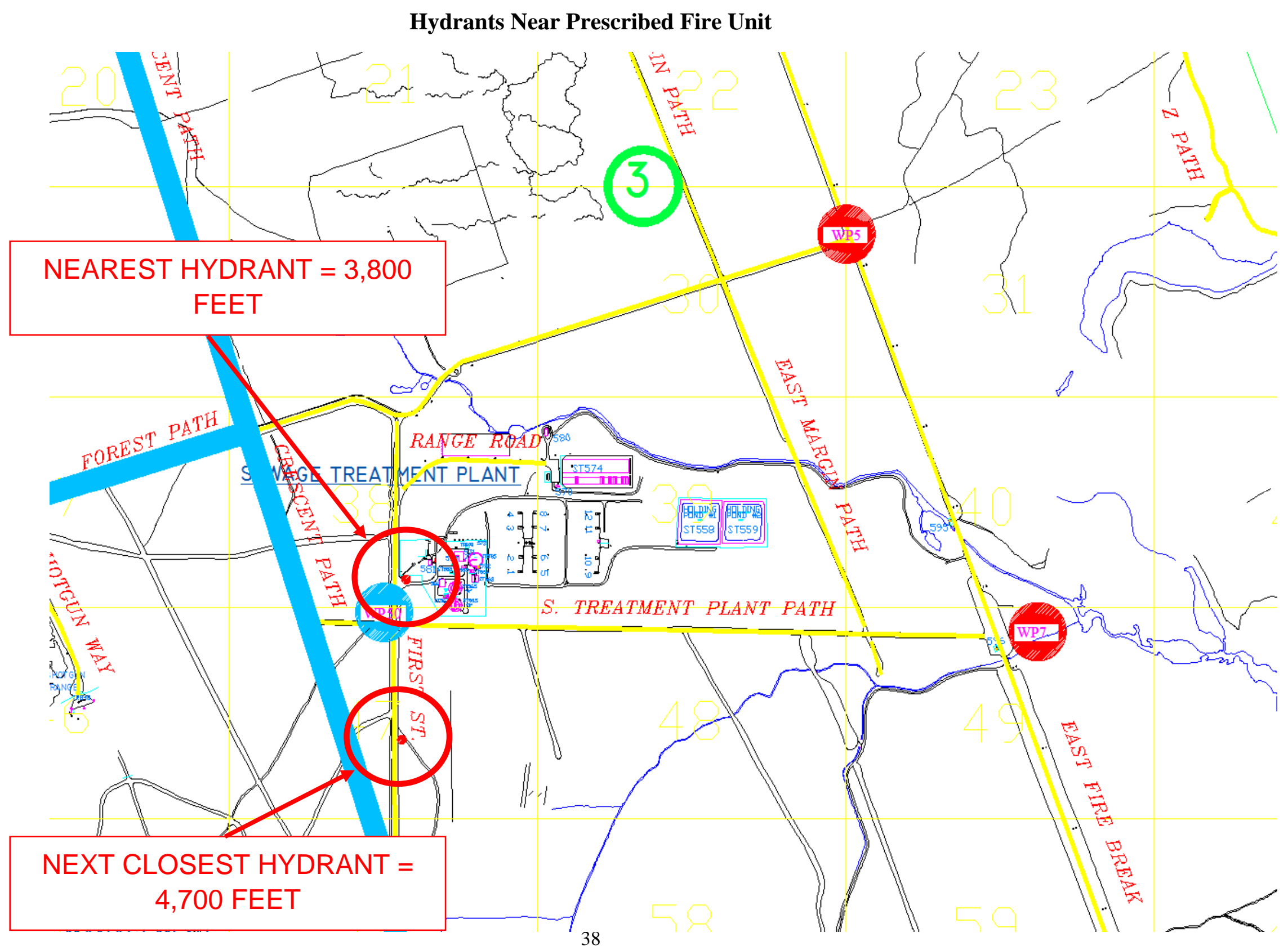




\section{Brookhaven National Lab} Northeast Burn Units Contingency Map

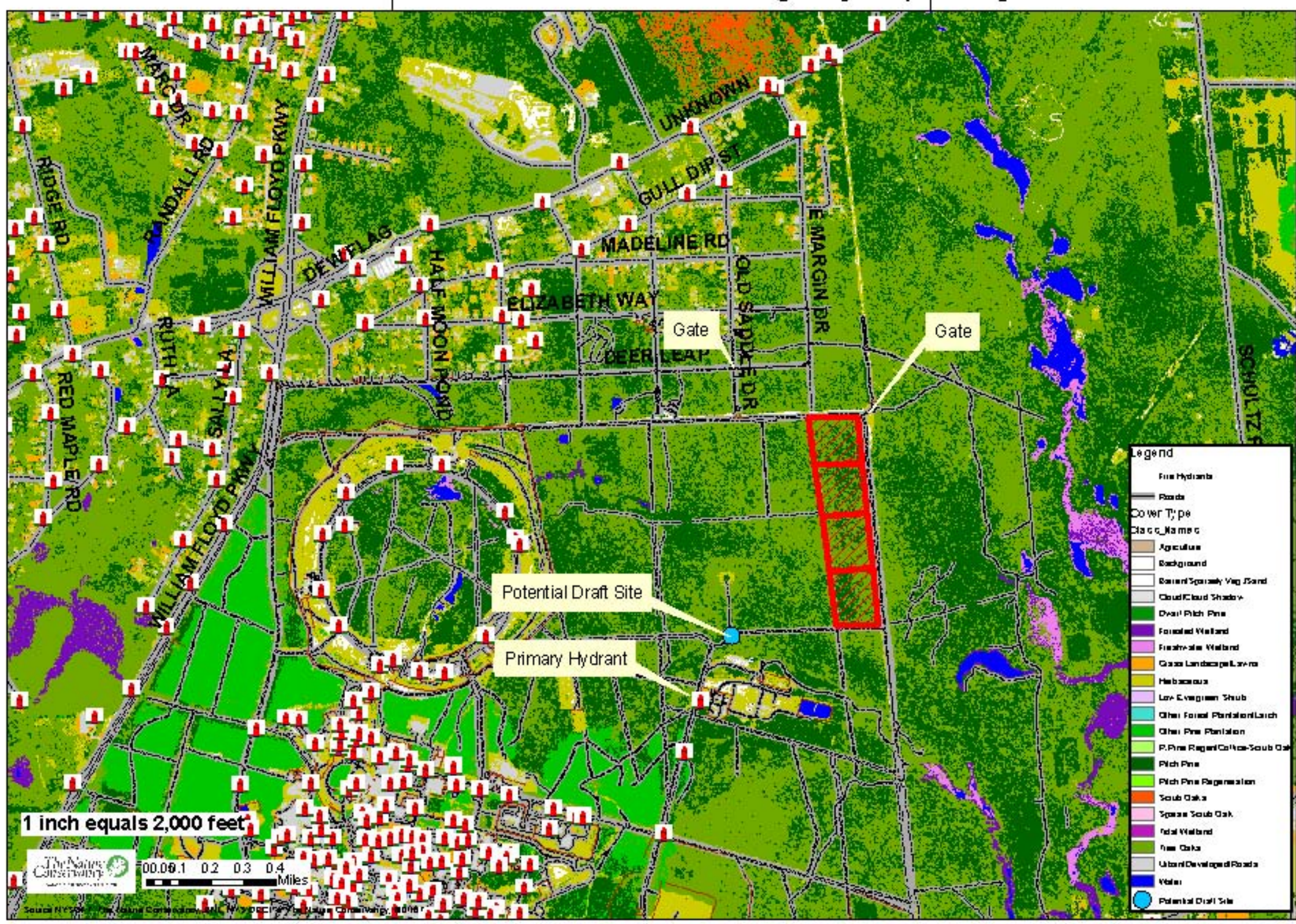




\section{B. TECHNICAL REVIEWER CHECKLIST}

\begin{tabular}{|c|c|c|}
\hline PRESCRIBED FIRE PLAN ELEMENTS: & $\mathbf{S} / \mathbf{U}$ & COMMENTS \\
\hline 1. Signature page & & \\
\hline 2. GO/NO-GO Checklists & & \\
\hline 3. Complexity Analysis Summary & & \\
\hline 4. Description of the Prescribed Fire Area & & \\
\hline 5. Goals and Objectives & & \\
\hline 6. Funding & & \\
\hline 7. $\quad$ Prescription & & \\
\hline 8. Scheduling & & \\
\hline 9. Pre-burn Considerations & & \\
\hline 10. Briefing & & \\
\hline 11. Organization and Equipment & & \\
\hline 12. Communication & & \\
\hline 13. Public and Personnel Safety, Medical & & \\
\hline 14. Test Fire & & \\
\hline 15. Ignition Plan & & \\
\hline 16. Holding Plan & & \\
\hline 17. Contingency Plan & & \\
\hline 18. Wildfire Conversion & & \\
\hline 19. Smoke Management and Air Quality & & \\
\hline 20. Monitoring & & \\
\hline 21. Post-burn Activities & & \\
\hline Appendix A: Maps & & \\
\hline Appendix B: Complexity Analysis & & \\
\hline Appendix C: JHA & & \\
\hline Appendix D: Fire Prediction Modeling Runs & & \\
\hline Other & & \\
\hline
\end{tabular}

S = Satisfactory $\quad U=$ Unsatisfactory

Recommended for Approval: Not Recommended for Approval:

Technical Reviewer Qualification and currency (Y/N) Date

$\checkmark$ Approval is recommended subject to the completion of all requirements listed in the comments section, or on the Prescribed Fire Plan. 
Unit Name: Brookhaven National Lab Northeast Units

\section{C: COMPLEXITY ANALYSIS}

\section{Prescribed Fire Complexity Rating System Guide Worksheet}

Instructions: This worksheet is designed to used with the Prescribed Fire Complexity Rating descriptors on

Page 6.

Project Name _ Brookhaven National Lab Northeastern Units Number

Complexity elements:

1. Potential for Escape

\begin{tabular}{|c|c|}
\hline Risk & Rationale \\
\hline $\begin{array}{l}\text { Preliminary Rating: } \\
\text { Low Moderate High }\end{array}$ & $\begin{array}{l}\text { The site is surrounded by roads and firebreaks. There are limited ladder fuels } \\
\text { and torching of mature trees not expected to be significant. Similar oak-pine } \\
\text { fuels surround the unit. Spots can be extinguished within a reasonable time. }\end{array}$ \\
\hline Final Rating: & \\
\hline Low Moderate High & \\
\hline Potential Consequences & Rationale \\
\hline $\begin{array}{l}\text { Preliminary Rating: } \\
\text { Low Moderate High }\end{array}$ & $\begin{array}{l}\text { An escape would not damage vegetation, habitat or other values in the } \\
\text { immediate area, however there is the potential to impact other properties and } \\
\text { structures if initial spot fires are not contained successfully }\end{array}$ \\
\hline $\begin{array}{l}\text { Final Rating: } \\
\text { Low Moderate High }\end{array}$ & \\
\hline Technical Difficulty & Rationale \\
\hline $\begin{array}{l}\text { Preliminary Rating: } \\
\text { Low Moderate High }\end{array}$ & $\begin{array}{l}\text { Given the low potential for escape, low fuel heights (and lack of ladder fuels), } \\
\text { and consistency in fuel loading, a small crew and single Burn Boss can safely } \\
\text { accomplish this project. }\end{array}$ \\
\hline $\begin{array}{l}\text { Final Rating: } \\
\text { Low Moderate High }\end{array}$ & \\
\hline
\end{tabular}


Unit Name: Brookhaven National Lab Northeast Units

2. The Number and Dependency of Activities

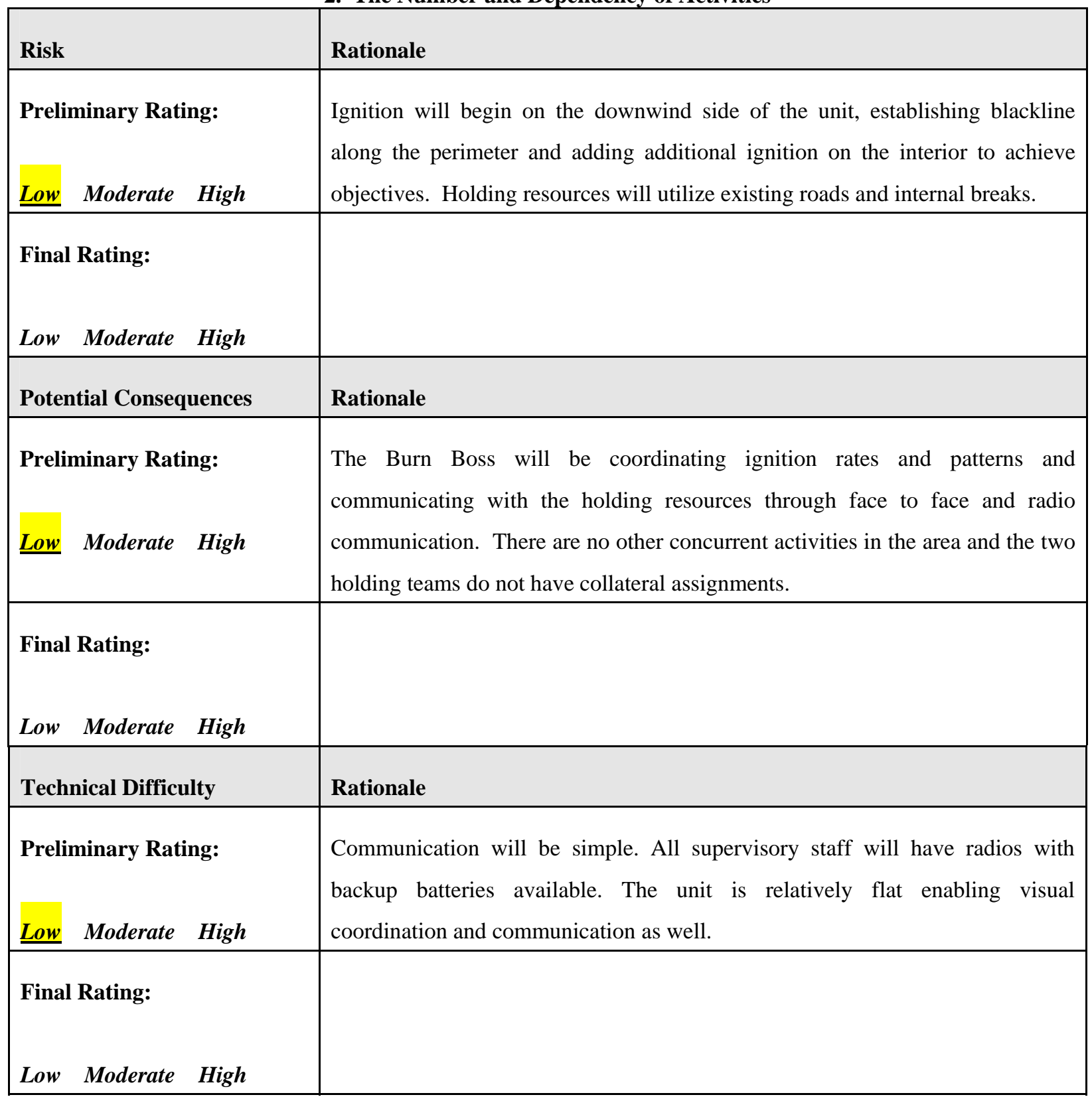




\section{Off-Site Values}

\begin{tabular}{|c|c|}
\hline Risk & Rationale \\
\hline Low Moderate High & $\begin{array}{l}\text { Due to the wide roads and firebreaks risk to structures and improvements } \\
\text { (power lines) is low. Fuels inside and outside the unit are similar. There should } \\
\text { be little to no visitor usage that would cause a threat to off-site values. }\end{array}$ \\
\hline Final Rating: & \\
\hline Low Moderate High & \\
\hline Potential Consequences & Rationale \\
\hline $\begin{array}{l}\text { Preliminary Rating: } \\
\text { Low Moderate High }\end{array}$ & $\begin{array}{l}\text { Just outside the burn unit are power lines and a small management station with } \\
\text { good defensible space. If an escape would move off property to the north } \\
\text { private property could be impacted. Suffolk County and New York State open } \\
\text { space could be impacted to the east. There should be little to no visitor usage. } \\
\text { No negative impacts to surrounding vegetation or habitat would be expected if } \\
\text { fire were to impact the off-site area. }\end{array}$ \\
\hline Final Rating: & \\
\hline Low Moderate High & \\
\hline Technical Difficulty & Rationale \\
\hline $\begin{array}{l}\text { Preliminary Rating: } \\
\text { Low Moderate High }\end{array}$ & $\begin{array}{l}\text { The protection of the off site values should be able to be accomplished with } \\
\text { trained crew on scene. No special management, equipment or skills are } \\
\text { anticipated to be needed. }\end{array}$ \\
\hline Final Rating: & \\
\hline Low Moderate High & \\
\hline
\end{tabular}




\section{On-Site Values}

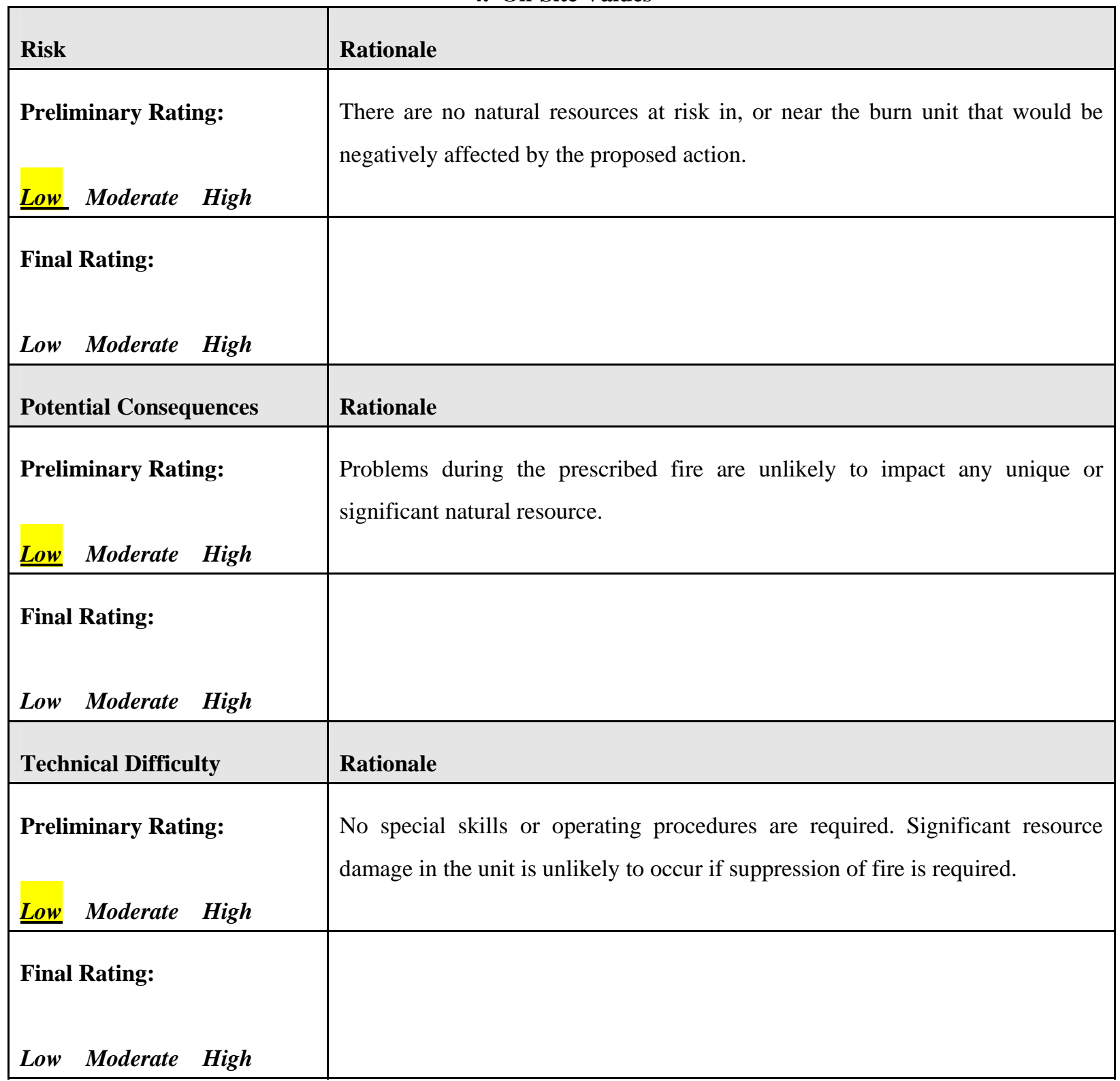


Unit Name: Brookhaven National Lab Northeast Units

5. Fire Behavior

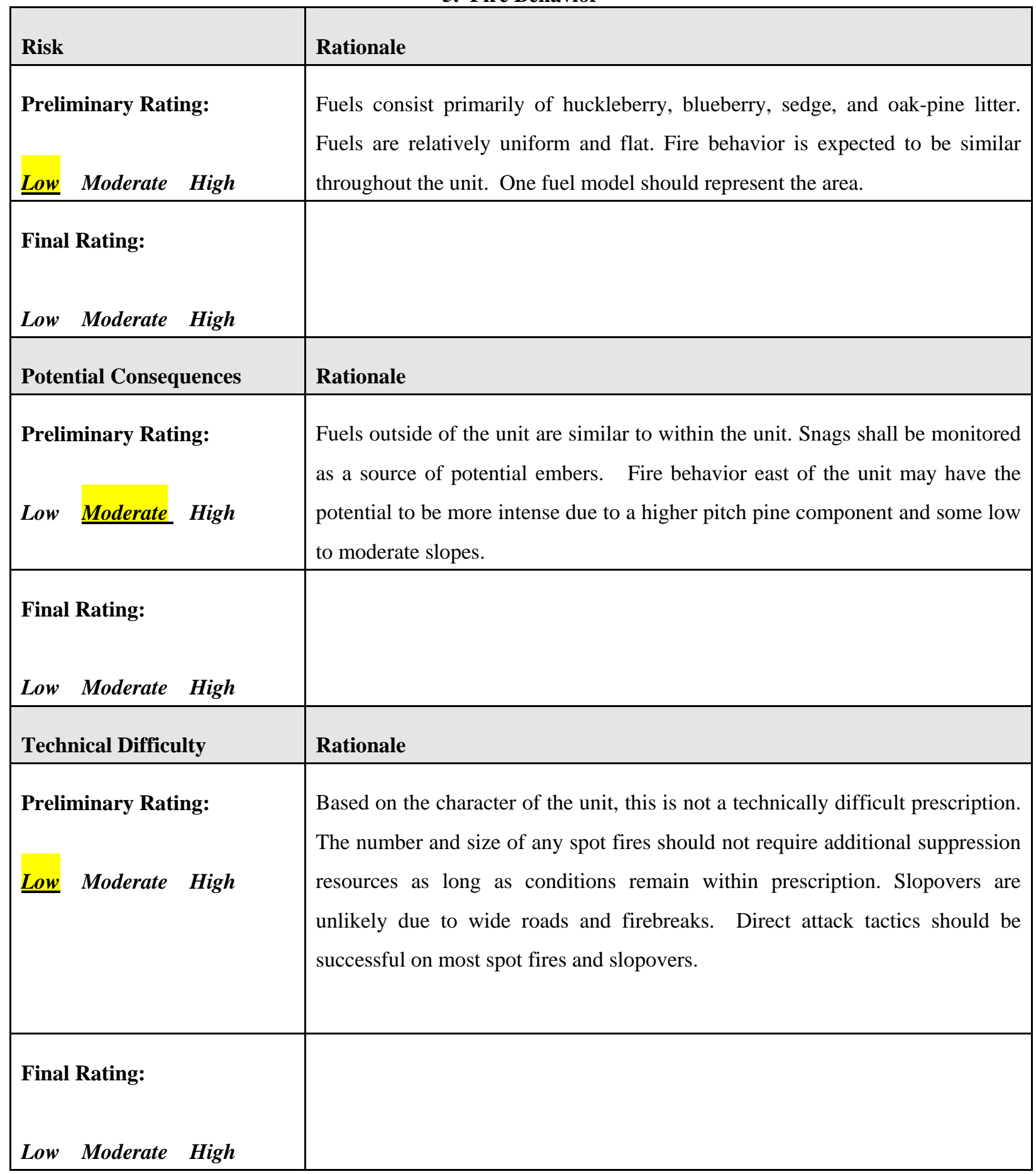




\section{Management Organization}

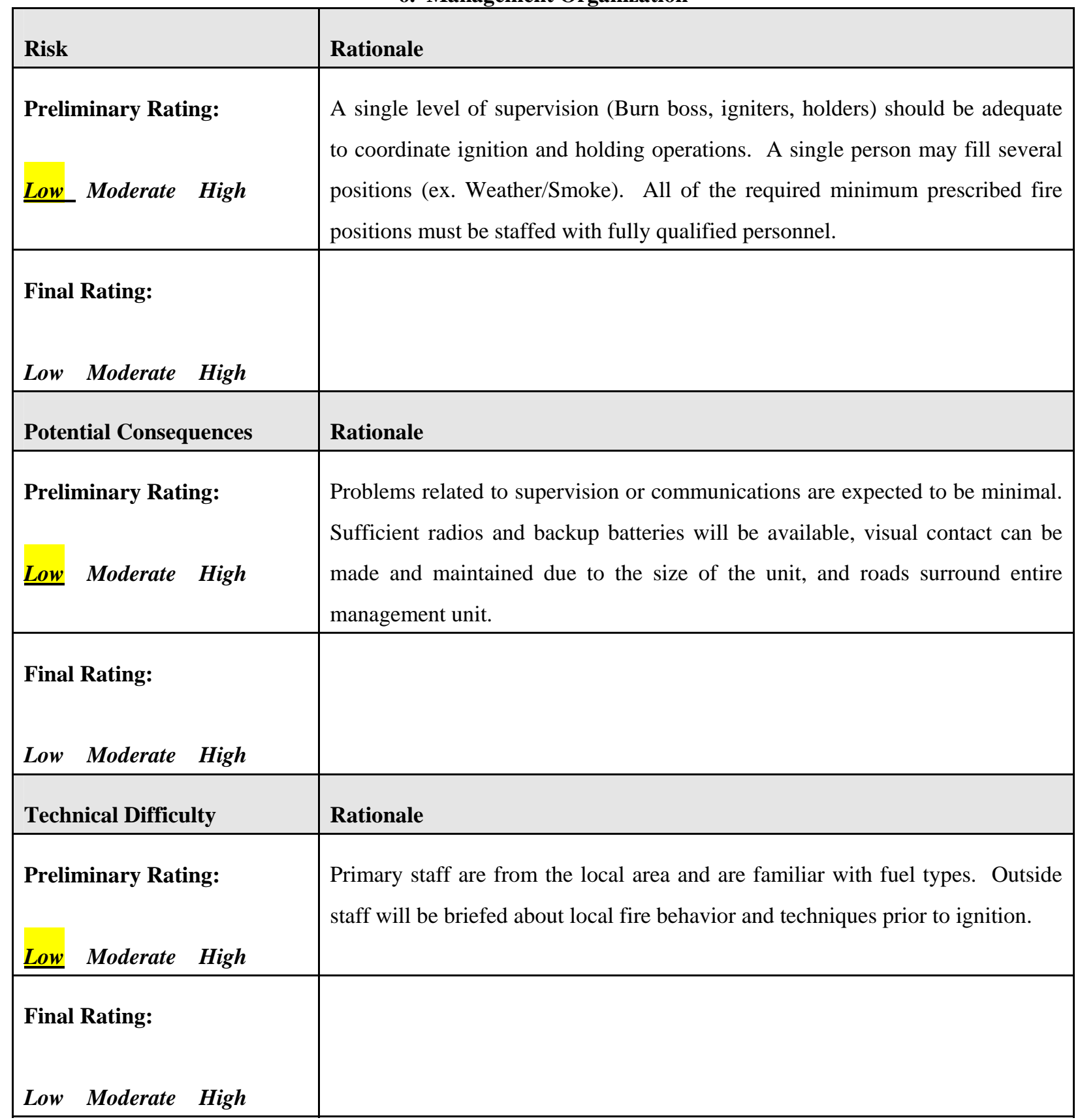




\section{Public and Political Interest}

\begin{tabular}{|l|l|}
\hline Risk & Rationale \\
\hline Preliminary Rating: & $\begin{array}{l}\text { Smoke from the fire may be visible from adjacent communities and roadways. } \\
\text { Some political controversy with animal rights groups have surfaced after past } \\
\text { prescribed fire activities, while other environmental groups support the activity. } \\
\text { Results of fire program have the interest of partner agencies and media outlets. }\end{array}$ \\
\hline Final Rating: & High \\
Low Moderate High & \\
\hline
\end{tabular}

\begin{tabular}{|c|c|}
\hline Potential Consequences & Rationale \\
\hline $\begin{array}{l}\text { Preliminary Rating: } \\
\text { Low Moderate High }\end{array}$ & $\begin{array}{l}\text { Unexpected or adverse events would attract media and political attention that } \\
\text { may delay implementation of other similar projects around the area and the } \\
\text { DOE complex. Communication planning has helped minimize impacts of } \\
\text { unintended events in the past on other properties. }\end{array}$ \\
\hline \multicolumn{2}{|l|}{ Final Rating: } \\
\hline Low Moderate High & \\
\hline Technical Difficulty & Rationale \\
\hline Preliminary Rating: & $\begin{array}{l}\text { No special fire information function is required. Standard notification } \\
\text { procedures will cover adequate flow of information. }\end{array}$ \\
\hline Low Moderate High & \\
\hline Final Rating: & \\
\hline Low Moderate High & \\
\hline
\end{tabular}




\section{Fire Treatment Objectives}

\begin{tabular}{|c|c|}
\hline Risk & Rationale \\
\hline$\underline{\text { Low }}$ Moderate High & $\begin{array}{l}\text { Fire objectives can be accomplished under a wide variety of conditions. Deep } \\
\text { fire or complete duff removal is not necessary. Vegetation and fuels monitoring } \\
\text { are conducted prior to and after treatments are applied. Fire weather and } \\
\text { behavior are monitored on site during the incident. }\end{array}$ \\
\hline Final Rating: & \\
\hline Low Moderate High & \\
\hline Potential Consequences & Rationale \\
\hline $\begin{array}{l}\text { Preliminary Rating: } \\
\text { Low Moderate High }\end{array}$ & $\begin{array}{l}\text { Failure to meet objectives in the short term will have few adverse impacts on the } \\
\text { natural resources. Fuel reduction objectives can only be accomplished with this } \\
\text { activity. }\end{array}$ \\
\hline Final Rating: & \\
\hline Low Moderate High & \\
\hline Technical Difficulty & Rationale \\
\hline $\begin{array}{l}\text { Preliminary Rating: } \\
\text { Low Moderate High }\end{array}$ & $\begin{array}{l}\text { Pre treatment monitoring is easy to complete following established protocols. } \\
\text { Monitoring during burn by the burn boss will determine rates and intensity of } \\
\text { ignition. }\end{array}$ \\
\hline Final Rating: & \\
\hline Low Moderate High & \\
\hline
\end{tabular}




\section{Constraints}

\begin{tabular}{|c|c|}
\hline Risk & Rationale \\
\hline $\begin{array}{l}\text { Preliminary Rating: } \\
\text { Low Moderate High }\end{array}$ & $\begin{array}{l}\text { Only weather related constraints have been identified at this time. Smoke } \\
\text { dispersion needs to be managed to ensure no impacts to roads, residences, and } \\
\text { intake fans of accelerator facilities. }\end{array}$ \\
\hline Final Rating: & \\
\hline Low Moderate High & \\
\hline Potential Consequences & Rationale \\
\hline Preliminary Rating: & Project can be implemented whenever it is in prescription. \\
\hline$\underline{\text { Low }}$ Moderate High & \\
\hline Final Rating: & \\
\hline Low Moderate High & \\
\hline Technical Difficulty & Rationale \\
\hline Preliminary Rating: & $\begin{array}{l}\text { Constraints should have little impact on achieving resource management } \\
\text { objectives. }\end{array}$ \\
\hline$\underline{\text { Low }}$ Moderate High & \\
\hline Final Rating: & \\
\hline Low Moderate High & \\
\hline
\end{tabular}


10. Safety

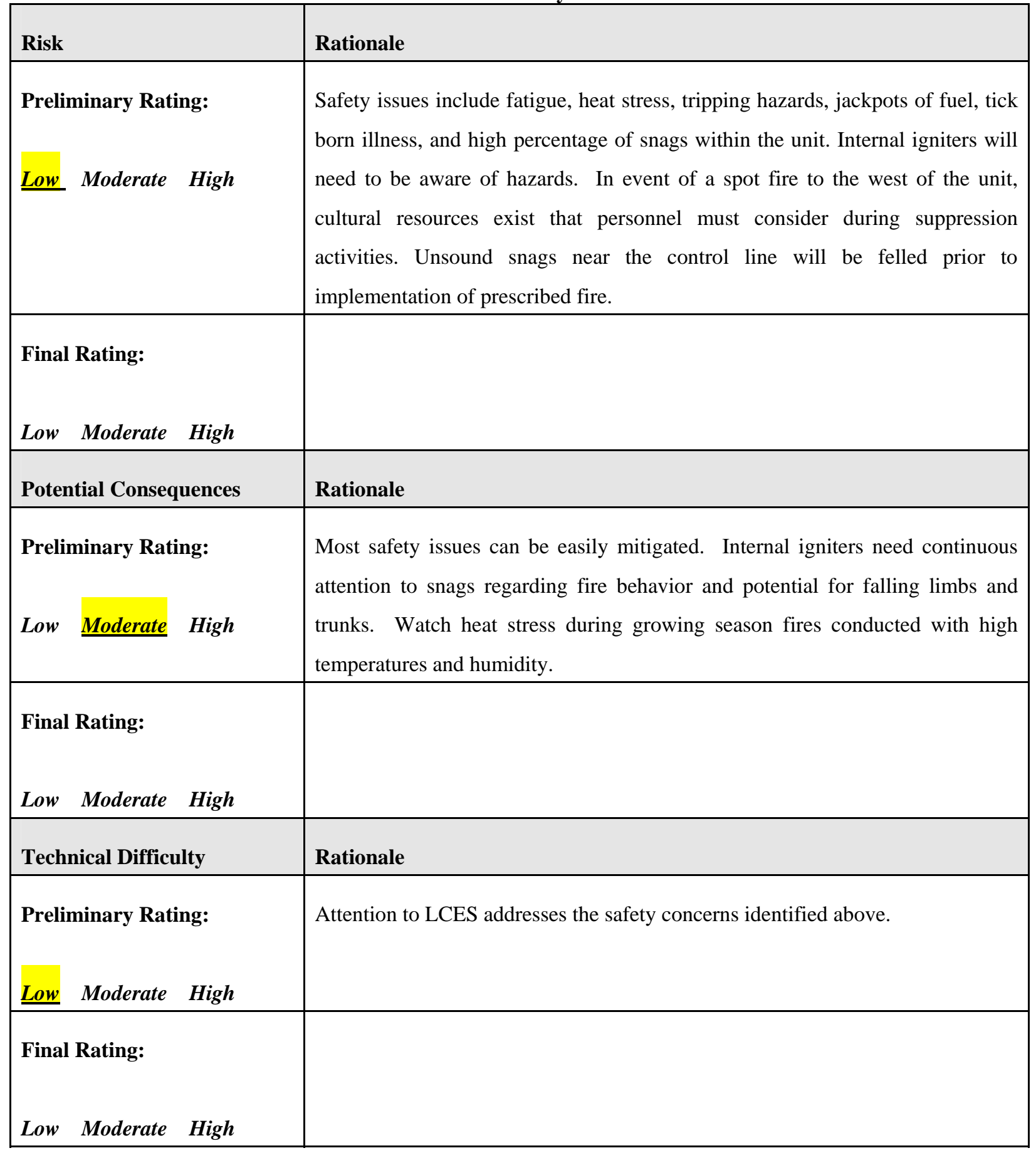




\section{Ignition Procedures/Methods}

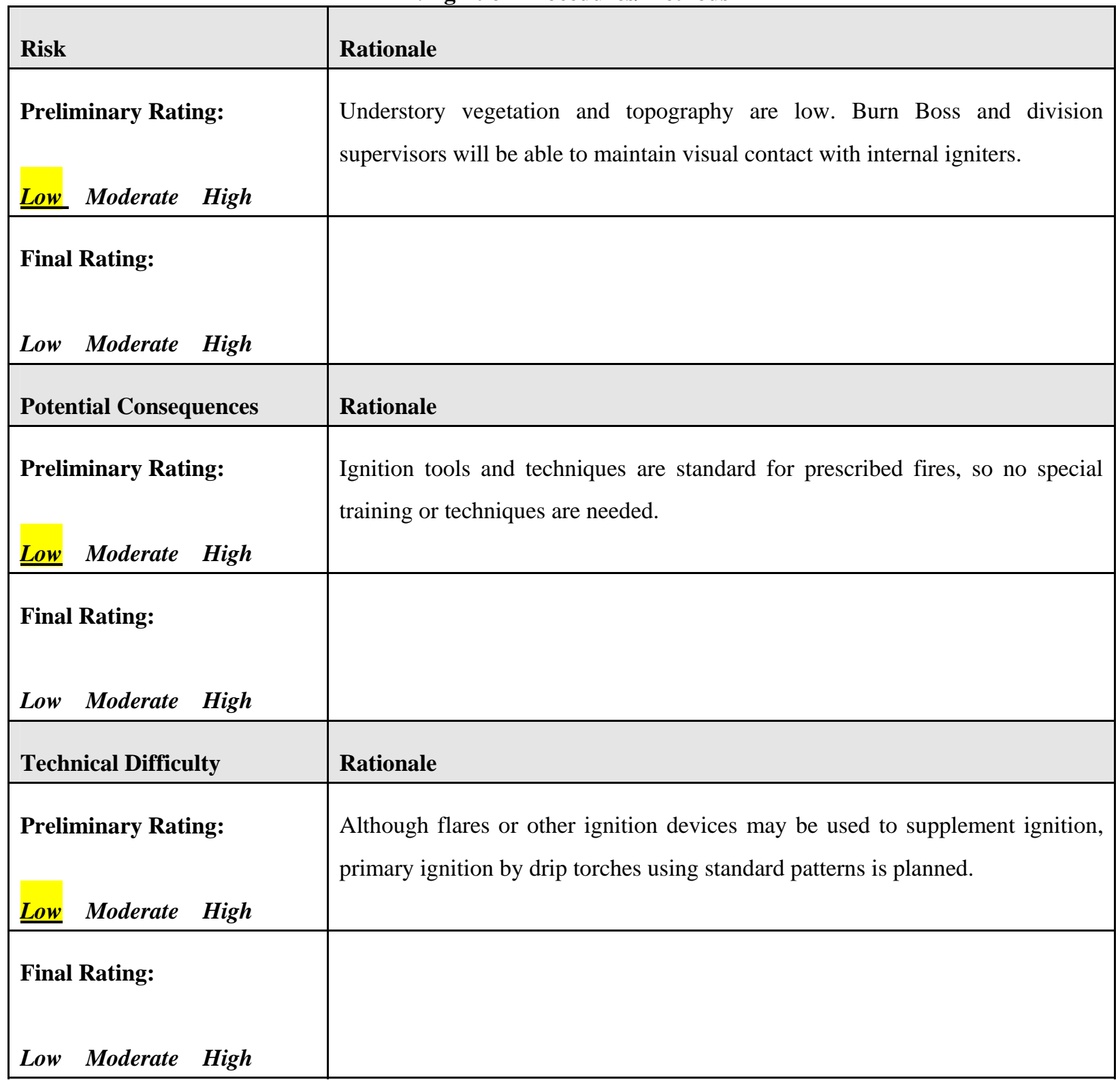




\section{Interagency Coordination}

\begin{tabular}{|c|c|}
\hline Risk & Rationale \\
\hline $\begin{array}{l}\text { Preliminary Rating: } \\
\underline{\text { Low Moderate High }}\end{array}$ & $\begin{array}{l}\text { Burn site is entirely within Brookhaven National Lab. State and NGO personnel } \\
\text { will assist with burn as in past projects. No special coordination will be } \\
\text { required. Units may be burned during the New York Wildfire \& Incident } \\
\text { Management Academy. The Incident Management Team may coordinate } \\
\text { activities if conducted during this time period. }\end{array}$ \\
\hline Final Rating: & \\
\hline Low Moderate High & \\
\hline Potential Consequences & Rationale \\
\hline Preliminary Rating: & $\begin{array}{l}\text { Project can be completed as planned. No State or local permits are required as } \\
\text { long as project has an approved plan. }\end{array}$ \\
\hline Low Moderate High & \\
\hline Final Rating: & \\
\hline Low Moderate High & \\
\hline Technical Difficulty & Rationale \\
\hline Preliminary Rating: & $\begin{array}{l}\text { Project requires the use of MOU's between the BNL, NYS-DEC, and TNC } \\
\text { unless conducted during the NYS Wildfire Academy. These are in place. }\end{array}$ \\
\hline Low Moderate High & \\
\hline Final Rating: & \\
\hline Low Moderate High & \\
\hline
\end{tabular}


13. Project Logistics

\begin{tabular}{|c|c|}
\hline Risk & Rationale \\
\hline $\begin{array}{l}\text { Preliminary Rating: } \\
\text { Low Moderate High }\end{array}$ & $\begin{array}{l}\text { No logistical support is anticipated. Supplies are available within each agency. } \\
\text { Ignition is expected to be completed in one day with rapid burnout of ignited } \\
\text { fuels. }\end{array}$ \\
\hline Final Rating: & \\
\hline Low Moderate High & \\
\hline Potential Consequences & Rationale \\
\hline Preliminary Rating: & Risk of an escaped fire will not be compromised by logistics \\
\hline Low Moderate High & \\
\hline Final Rating: & \\
\hline Low Moderate High & \\
\hline Technical Difficulty & Rationale \\
\hline Preliminary Rating: & No logistical support is anticipated \\
\hline Low Moderate High & \\
\hline Final Rating: & \\
\hline Low Moderate High & \\
\hline
\end{tabular}




\section{Smoke Management}

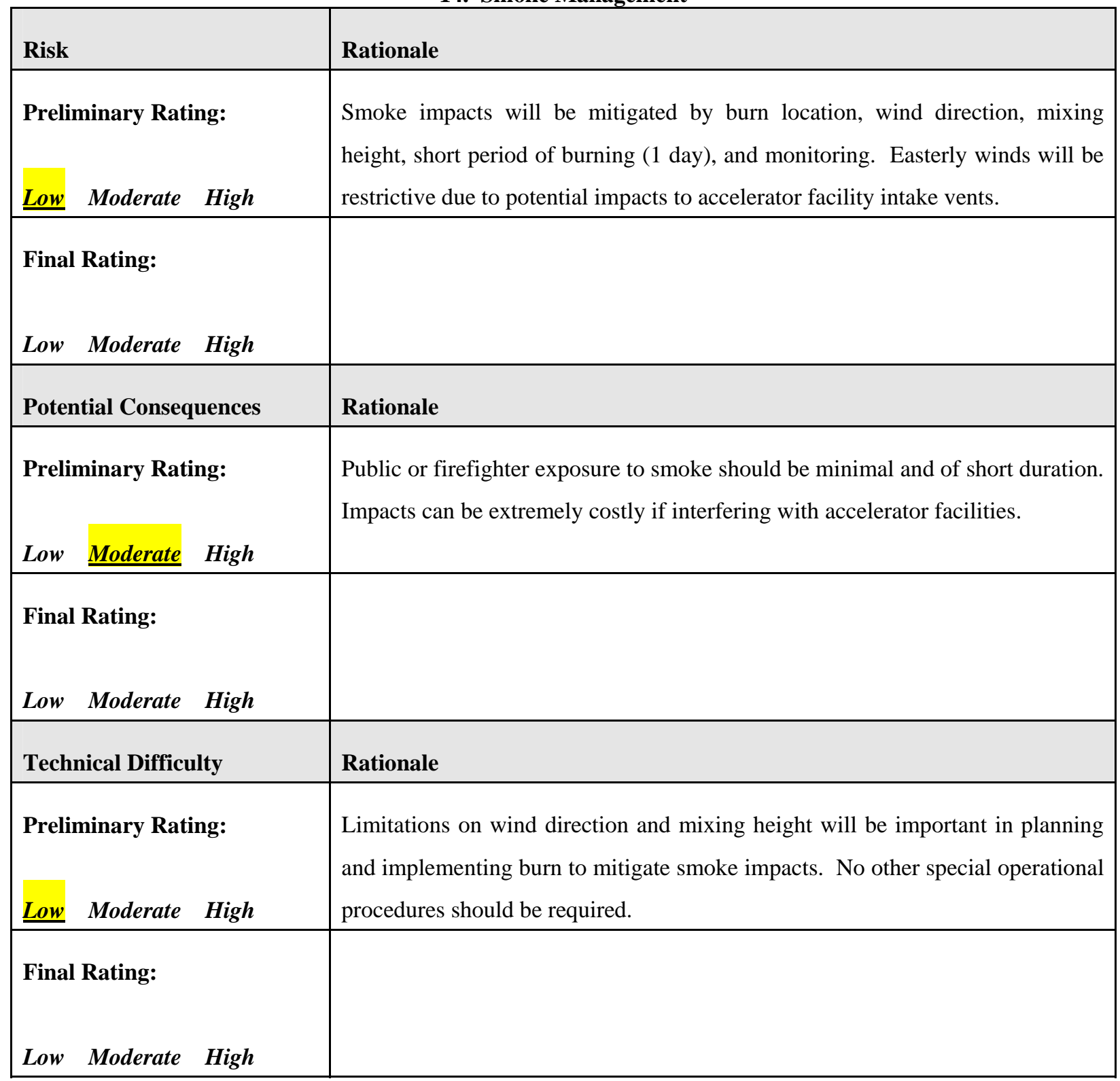




\section{COMPLEXITY RATING SUMMARY}

RISK

POTENTIAL CONSEQUENCES

TECHNICAL DIFFICULTY
OVERALL RATING

OVERALL RATING

LOW / MODERATE

OVERALL RATING

LOW

\section{SUMMARY COMPLEXITY RATING}

\section{LOW}

RATIONALE: The proposed action requires standard burn methods, coordination, safety mitigation and communication. BNL has a few private residences to the north and infrastructure to the west and southwest of the unit. These areas are not immediately adjacent to the burn unit. Any fire outside of the intended unit has the potential for containment prior to impacting these values. Contingency planning addresses these potential consequences with BNL fire department near the burn site and fully staffed. The safety and risk factors are mitigated by low fuel loading / fuel bed depth and wide roads surrounding unit.

Prepared by:

Brian Kurtz

Date:

$9 / 18 / 2007$

Approved by: _ Tim Green

Date: $\quad 10 / 01 / 2007$

(Agency Administrator) 
Administrative Unit: BROOKHAVEN NATIONAL LABORATORY

Unit Name: Brookhaven National Lab Northeast Units

\section{JOB HAZARD ANALYSIS}

\section{See following pages.}




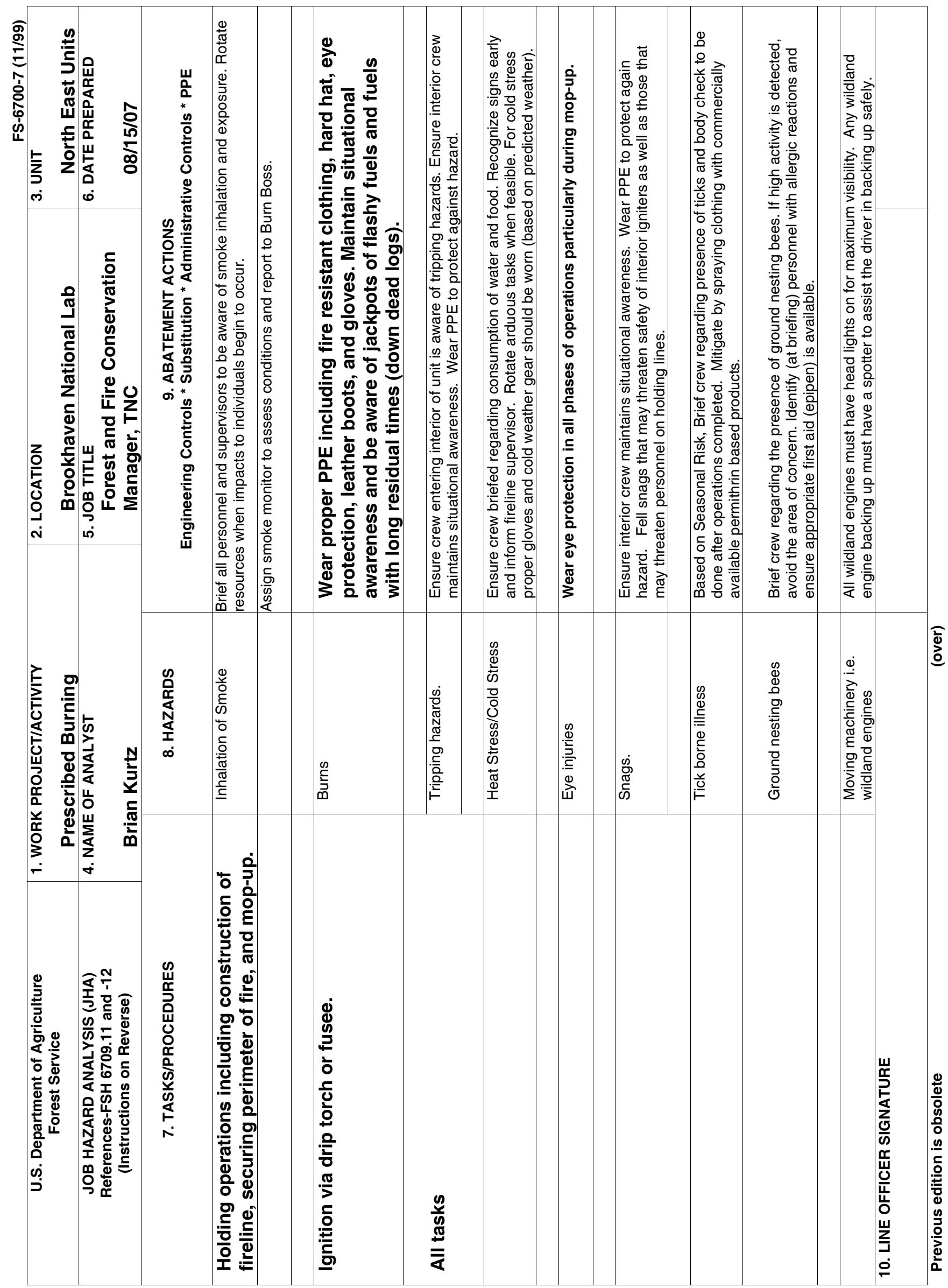




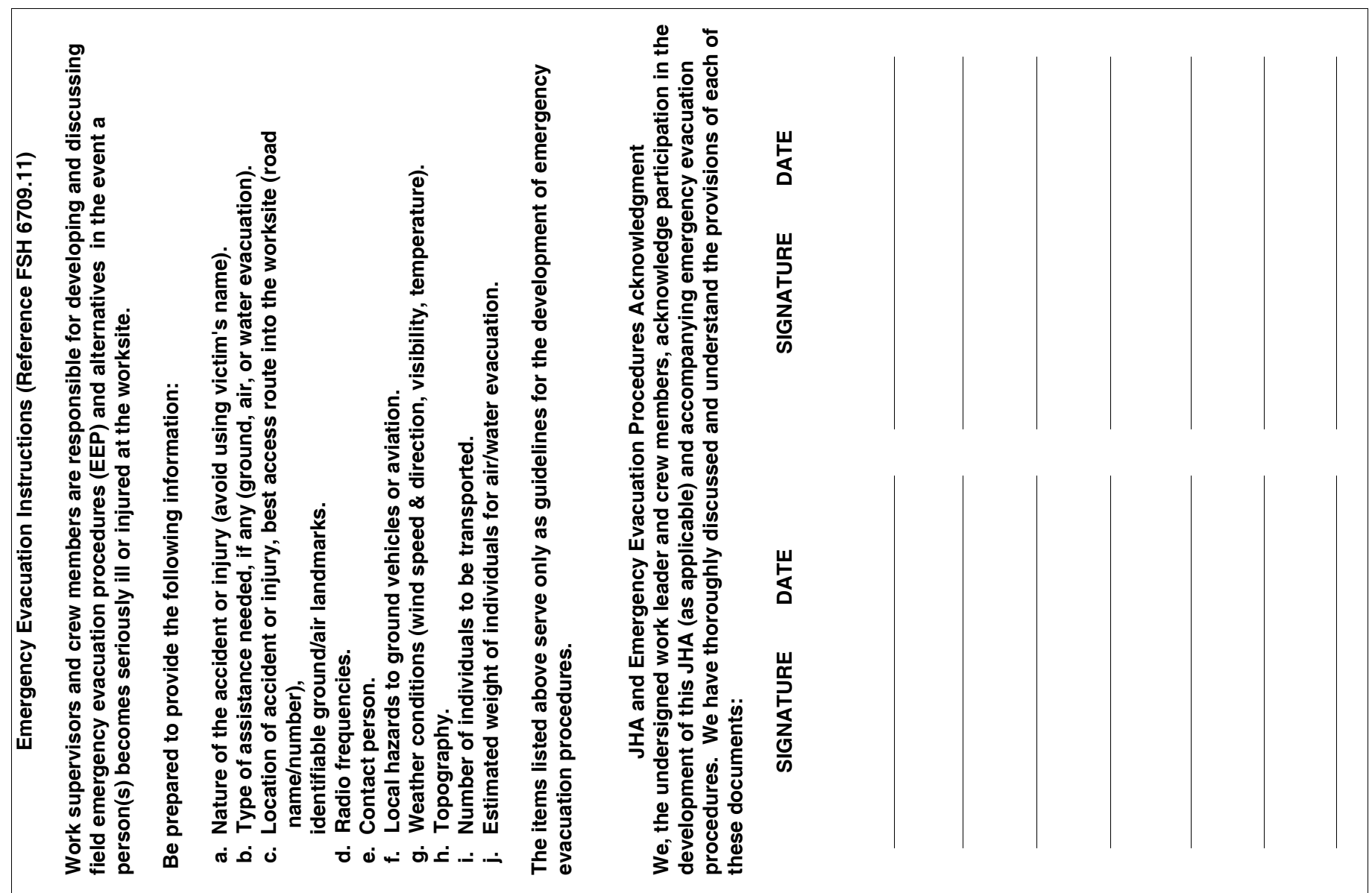

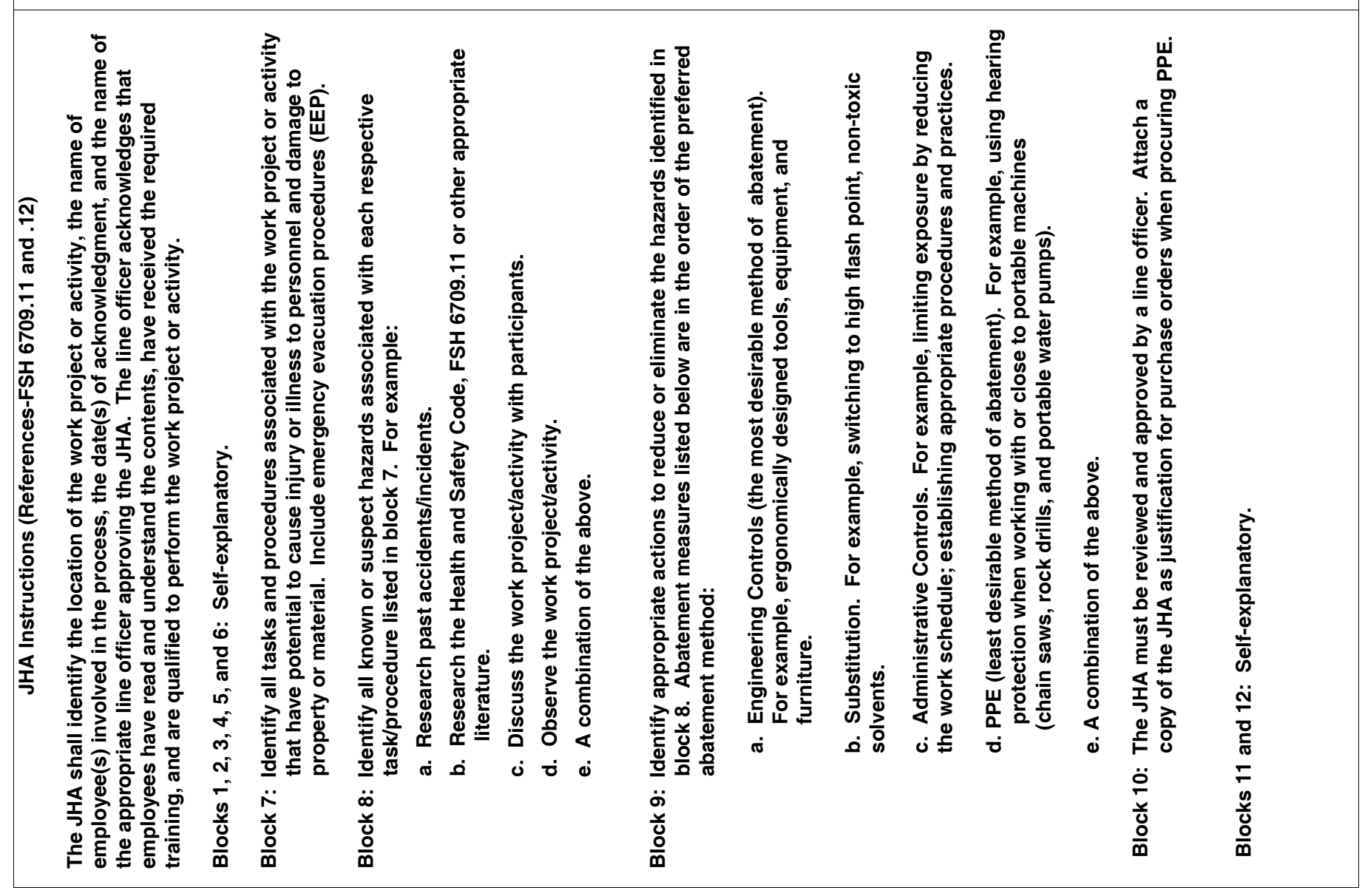




\section{E. FIRE BEHAVIOR MODELING DOCUMENTATION OR EMPIRICAL DOCUMENTATION}

Fire behavior model from multiple BEHAVE Runs is available and on file for this burn unit. The BEHAVE Runs constitute 94 pages of data. 
B. TECHNICAL REVIEWER CHECKLIST

\begin{tabular}{|c|c|c|}
\hline PRESCRIBED FIRE PLAN ELEMENTS: & $\mathbf{S} / \mathbf{U}$ & COMMENTS \\
\hline 1. Signature page & S & \\
\hline 2. GO/NO-GO Checklists & S & \\
\hline 3. Complexity Analysis Summary & $\mathrm{S}$ & \\
\hline 4. Description of the Prescribed Fire Area & $\mathrm{S}$ & \\
\hline 5. Goals and Objectives & S & \\
\hline 6. Funding & $\mathrm{S}$ & \\
\hline 7. Prescription & S & $\begin{array}{l}\text { Hot end of prescription is within capabilities of minimum } \\
\text { holding resources per burn plan and are in line with } \\
\text { similar burns done regionally. }\end{array}$ \\
\hline 8. Scheduling & $\mathrm{S}$ & \\
\hline 9. Pre-burn Considerations & S & $\begin{array}{l}\text { Ensure snags with potential for compromising safety on } \\
\text { perimeters (control lines) are taken care of before burn. }\end{array}$ \\
\hline 10. Briefing & S & \\
\hline 11. Organization and Equipment & $\mathrm{S}$ & \\
\hline 12. Communication & $\mathrm{S}$ & \\
\hline 13. Public and Personnel Safety, Medical & $\mathrm{S}$ & \\
\hline 14. Test Fire & $\mathrm{S}$ & \\
\hline 15. Ignition Plan & $\mathrm{S}$ & \\
\hline 16. Holding Plan & $\mathrm{S}$ & \\
\hline 17. Contingency Plan & $\mathrm{S}$ & \\
\hline 18. Wildfire Conversion & S & \\
\hline 19. Smoke Management and Air Quality & $\mathrm{S}$ & $\begin{array}{l}\text { You may want to revise the Permit section. A NYS-DEC } \\
\text { burn permit is not required. The burn plan has been } \\
\text { reviewed by our office. If you have an approved burn } \\
\text { plan, the burn permit is unnecessary. }\end{array}$ \\
\hline 20. Monitoring & $\mathrm{S}$ & \\
\hline 21. Post-burn Activities & $\mathrm{S}$ & \\
\hline Appendix A: Maps & S & \\
\hline Appendix B: Complexity Analysis & $\mathrm{S}$ & \\
\hline Appendix C: JHA & S & \\
\hline Appendix D: Fire Prediction Modeling Runs & S & $\begin{array}{l}\text { Fire prediction was run with Behave } 4.0 .0 \text { during } 2009 \\
\text { tech review. Fire behavior details in plan are satisfactory. }\end{array}$ \\
\hline Other & N/A & \\
\hline
\end{tabular}

S=Satisfactory U=Unsatisfactory Recommended for Approval: Yes Not Recommended for Approval:

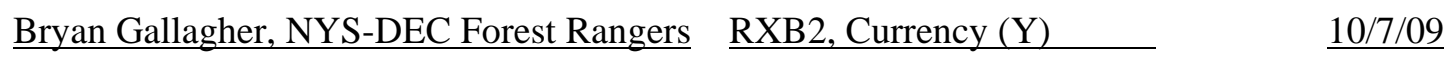

Technical Reviewer

Qualification \& Currency (Y/N) Date

Approval is recommended subject to the completion of all requirements listed in the comments section, or on the Prescribed Fire Plan. 


\section{Appendix D: Detection and Dispatch Plan, Staffing Table}

\begin{tabular}{|c|c|c|c|c|}
\hline Alarm & Definition & BNL Resources & \multicolumn{2}{|c|}{ SC FRES Dispatch and Notification } \\
\hline $\begin{array}{l}\text { First } \\
\text { Alarm }\end{array}$ & $\begin{array}{l}\text { Incipient stage fire, well within the resources of BNL FD to } \\
\text { extinguish; or a moderate fire in which BNL FD \& } \\
\text { immediate mutual aid will extinguish. No other resources } \\
\text { are needed. }\end{array}$ & $\begin{array}{l}\text { - } \quad \text { BNL Brush } 3 \text { \& Command } \\
\text { - } \quad \text { BNL Security } \\
\text { Pager notification for information }\end{array}$ & \multicolumn{2}{|c|}{$\begin{array}{l}\text { As requested BNL Incident Command: } \\
1 \text { Stump Jumper from Ridge, } 1 \text { Stump Jumper from Manorville, and/or } 1 \\
\text { Stump Jumper from Yaphank }\end{array}$} \\
\hline $\begin{array}{l}\text { Second } \\
\text { Alarm }\end{array}$ & $\begin{array}{l}\text { Fire(s) are clearly on BNL property and beyond BNL FD } \\
\text { resources. }\end{array}$ & 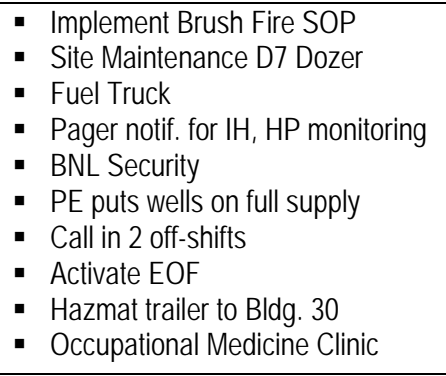 & $\begin{array}{l}\text { Summon an additional: } \\
4 \text { Stump Jumpers } \\
3 \text { Tankers } \\
2 \text { Engines (1 for BNL Coverage*) } \\
1 \text { Heavy Rescue*(BNL Coverage) } \\
1 \text { Ambulance* (BNL Coverage) } \\
1 \text { Rehabilitation Unit }\end{array}$ & $\begin{array}{l}\text { - SC Fire Coordinator } \\
\text { - SC EMS Coordinator } \\
\text { - Brookhaven Town Tank } \\
\text { retriever } \\
\text { - SCPD Helicopter } \\
\text { - SEMO (518) 457-2200 } \\
\text { (information only) } \\
\text { - US Forest Service (610) } \\
\text { 557-4146 (Information only } \\
\text { for NYS Forest Ranger) } \\
\end{array}$ \\
\hline $\begin{array}{l}\text { Third } \\
\text { Alarm }\end{array}$ & $\begin{array}{l}\text { Fire(s) require additional resources for relief and for } \\
\text { structural protection on site. }\end{array}$ & $\begin{array}{ll}\text { - } & \text { BNL Housing } \\
\text { - } & \text { BNL Cafeteria } \\
\text { - } & \text { Vehicle Repair }\end{array}$ & $\begin{array}{l}\text { Summon an additional } \\
7 \text { Stump Jumpers } \\
3 \text { Tankers } \\
4 \text { Engines } \\
1 \text { Ambulance } \\
1 \text { Rehabilitation Unit } \\
1 \text { Heavy Rescue } \\
\end{array}$ & $\begin{array}{l}\text { - SC Command Vehicle } \\
\text { - NYS Forest Rangers } \\
\text { - } \text { Fire Island National } \\
\text { Seashore Rangers } \\
\text { - } \text { Air guard / Army Helicopters } \\
\text { (Bambi Buckets) }\end{array}$ \\
\hline $\begin{array}{l}\text { Fourth } \\
\text { Alarm }\end{array}$ & $\begin{array}{l}\text { Fire(s) require additional resources for structural protection } \\
\text { on site that are threatened by fire. }\end{array}$ & & $\begin{array}{l}\text { Summon an additional: } \\
6 \text { Stump Jumpers } \\
1 \text { Tanker } \\
5 \text { Engines } \\
4 \text { Ambulances } \\
1 \text { Rehabilitation Unit }\end{array}$ & $\begin{array}{l}\text { - Brookhaven/Riverhead } \\
\text { Town Heavy Equipment } \\
\text { - LIPA } \\
\text { - Verizon }\end{array}$ \\
\hline $\begin{array}{l}\text { Emer- } \\
\text { gency } \\
\text { Medical } \\
\text { Services }\end{array}$ & \multicolumn{4}{|c|}{$\begin{array}{l}\text { The EMS response by Incident Command will consider the following: } \\
\text { 1) Medical aid for Firefighters \& other Emergency Response Personnel working the incident } \\
\text { 2) Rehabilitation of the Firefighters \& Emergency Response Personnel } \\
\text { 3) Normal EMS response to BNL employees } \\
\text { 4) Normal EMS response to surrounding Departments (Ridge \& Manorville), such as, MVA at Main Gate or on William Floyd Parkway, emergencies } \\
\text { in the immediate vicinity of BNL, in which the resources are available to respond from BNL }\end{array}$} \\
\hline
\end{tabular}


This page intentionally blank. 


\section{Appendix E: Maps}

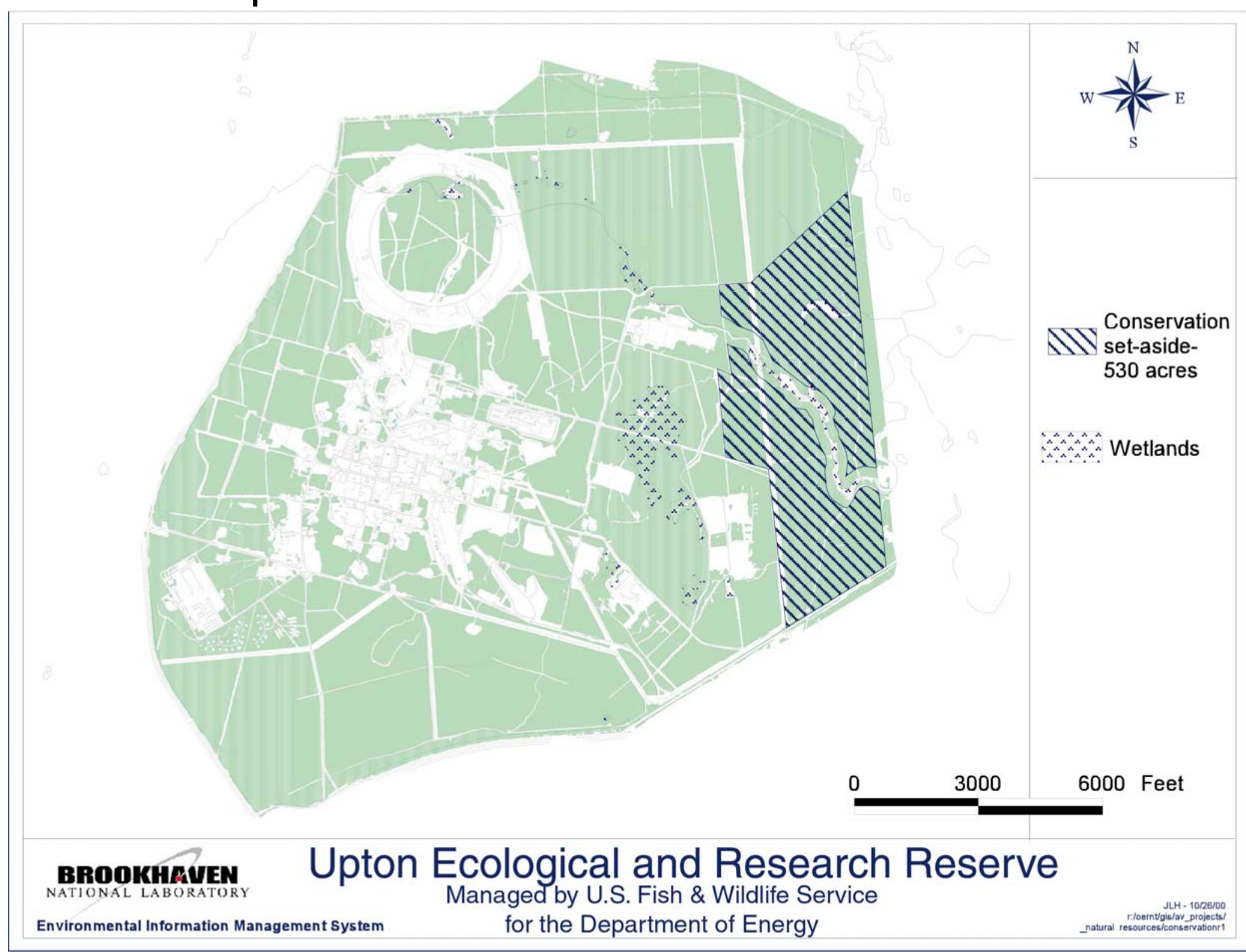




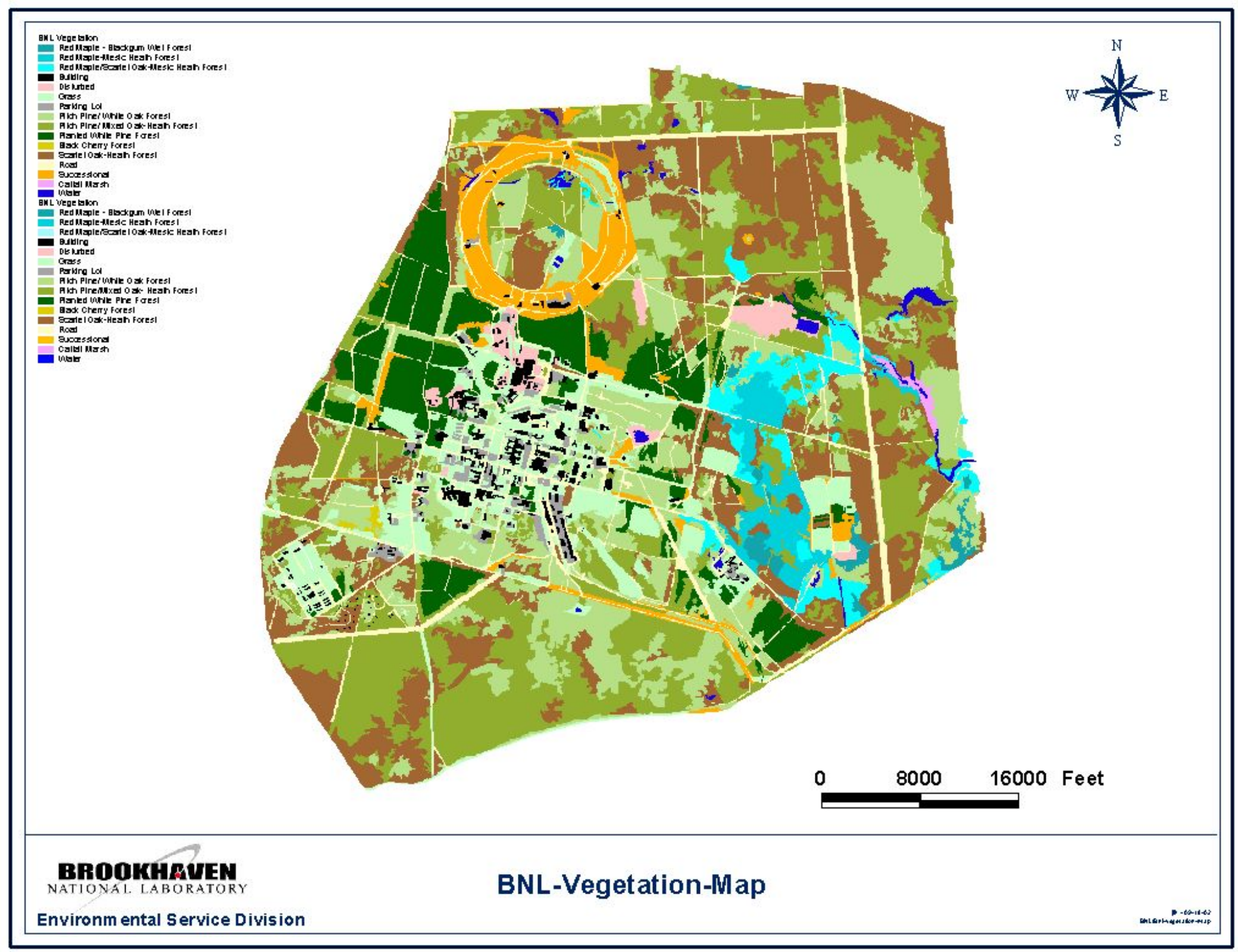




\section{Appendix F: BNL Wildland Fire Hazard Severity Analysis}

Note: If this section is missing from your document, you may go to:

http://www.bnl.gov/emergencyservices/FP/Wildland-fire/files/pdf/Wildfire\%20Planning\%20Report.pdf and download the PDF file. 
Brookhaven National Laboratory

\section{BNL Wildland Fire Assessment}

\section{Wildland Fire Hazard Severity Analysis, Issues \& Needs}

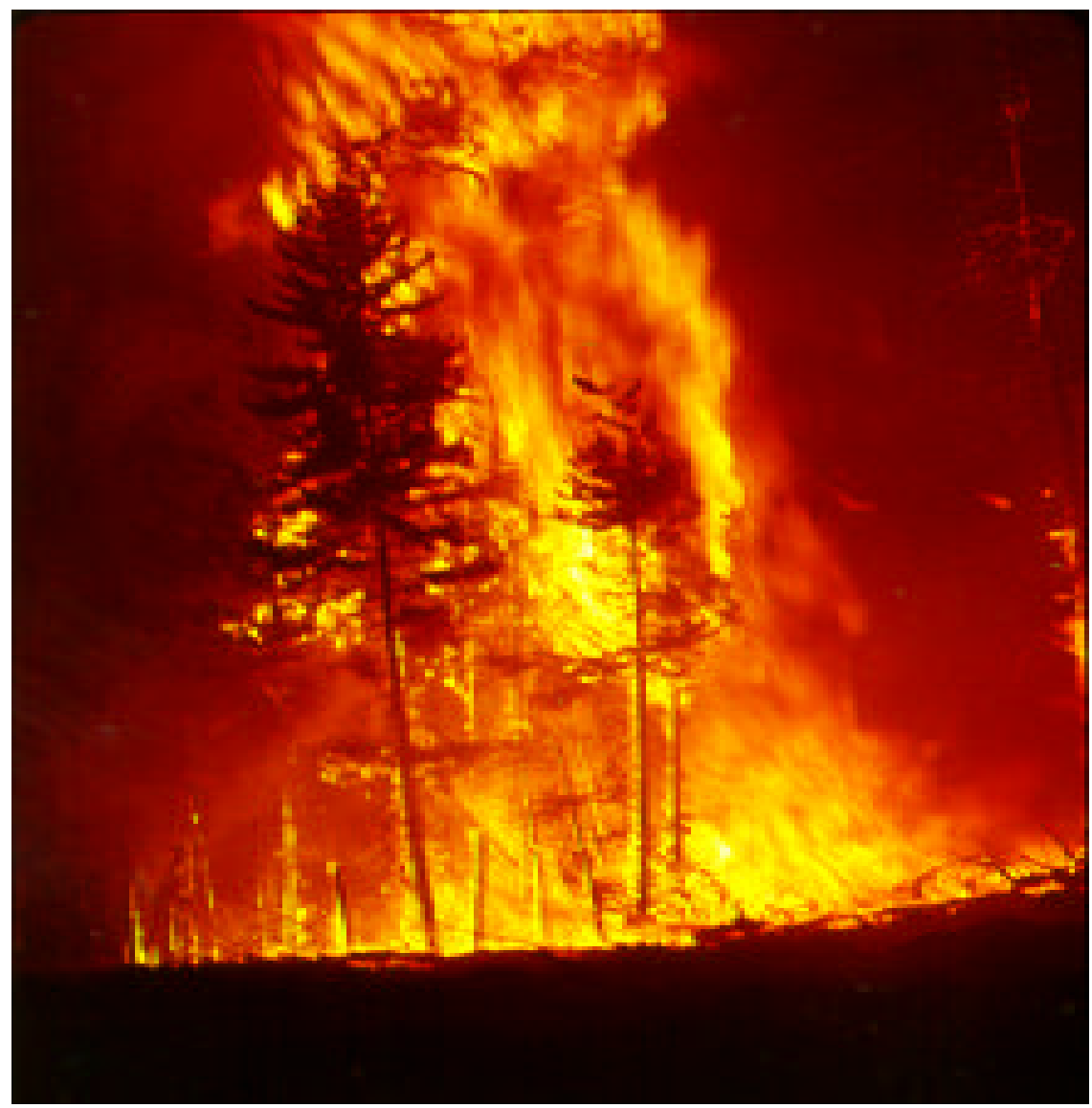




\section{Executive Summary}

BNL's operations are vulnerable to damage from fires in wildland ${ }^{1}$ areas. Using a nationally recognized model, the severity of BNL wildland fire ${ }^{2}$ hazard is "moderate." Adequate precautions are in place to minimize facility involvement in most major locations. Several physical improvements are needed in the wildlands interface zones to avoid loss of site power for several months with property damage approaching $\$ 1$ million. Additionally, the management system defining and maintaining the fire breaks/defensible spaces ${ }^{3}$ around BNL should be formalized to document the protective systems currently in place. The topic of prescribed burns to reduce fuel-loading also needs to be explored. A Fire Management Plan, possibly integrated into the BNL Natural Resource Management Plan, should be used to formalize these issues.

Wildland fires have an excellent transport capability. With the intense heat and destruction of materials in the fire's path, the fire plumes can transport particulate from burning radiological materials. The radiological material must be capable of dispersion. Soil contamination is not automatically a release pathway. Due to the lack of properly quantified radiological uptake into vegetation in the BNL wildland, this topic could not be fully explored. The Environmental Restoration Division has characterized several likely sites of soil contamination. How much of the radiological material has been taken up by the vegetation has not been defined clearly. All indications are that up take is very low. As these particles, suspended in the smoke column, move there is a high degree of dilution. Often quantities can only be calculated and not measured. Increased sampling of vegetation is needed to provide a site wide profile and affirm the low level of possible release.

\footnotetext{
${ }^{1}$ As defined by the National Fire Protection Association, wildlands are "land in an uncultivated, more or less natural state and covered by timber, woodland, brush, and/or grass."

${ }^{2}$ As defined by the National Fire Protection Association, wildland fires or wildfires are "any uncontrolled fire bringing in wildlands vegetation including any structure or other improvements thereon."

${ }^{3}$ Defensible spaces are regions between wildlands and structures minimize the direct impact by a wildland fire on the structure and allow fire department suppression.
} 


\section{Action Item Table}

\begin{tabular}{|c|c|c|}
\hline Action Item & $\begin{array}{c}\text { Target } \\
\text { Date }\end{array}$ & Responsible Party \\
\hline $\begin{array}{l}\text { Action Item \#1: ATS 361.2.1 To allow access to the } \\
\text { Northeast region of the BNL Pine Barren area, the access } \\
\text { road running north to south between the right of way of the } \\
\text { east power line and North Street should be made passable. }\end{array}$ & $5 / 1 / 01$ & Tom Roza, EP \\
\hline $\begin{array}{l}\text { Action Item \#2: ATS } 361.2 .2 \text { Identify required firebreaks } \\
\text { access roads, paths, and ways to provide consistent } \\
\text { nomenclature for normal operations (PE, ERD, Fire/Rescue), } \\
\text { outside fire department operations, and operations of the new } \\
\text { nature preserve. Identification of fire breaks should be } \\
\text { incorporated into BNL Site maps. }\end{array}$ & $5 / 01 / 01$ & Joe Levesque, EM \\
\hline $\begin{array}{l}\text { Action Item \#3: ATS } 361.2 .3 \text { Establish a policy to provide } \\
\text { identification of Firebreaks and Access Roads with street } \\
\text { signs meeting NFPA } 299 .\end{array}$ & $5 / 01 / 01$ & Frank Marotta, EM \\
\hline $\begin{array}{l}\text { Action Item \#4: ATS 361.2.4 Submit a funding request to } \\
\text { restore the second means of egress for the Summer Cottage } \\
\text { Area (Mendel and Aston Lanes). }\end{array}$ & $5 / 01 / 01$ & Joe Levesque \\
\hline $\begin{array}{l}\text { Action Item \# 5: ATS 361.2.5 Evaluate the need for an } \\
\text { eastern emergency exit from the BNL site. The most viable } \\
\text { solution maybe to pave Brookhaven Avenue from Bldg. } 445 \\
\text { to the Southeast exit to North Street. }\end{array}$ & $7 / 01 / 01$ & Ken Krasner, EM \\
\hline $\begin{array}{l}\text { Action Item \#6: ATS } 361.2 .6 \text { BNL sponsored camping and } \\
\text { softball activities have potential ignition sources for a wildland } \\
\text { fire. Safeguards should be developed and implemented for } \\
\text { camping, campfires, and disposal of hot ashes and Bar-B-Q } \\
\text { grill placement. The camping area should be posted with } \\
\text { safety rules and emergency contact information. }\end{array}$ & $7 / 01 / 01$ & Peter Esposito, HRS \\
\hline $\begin{array}{l}\text { Action Item \#7: ATS 361.2.7 While developing a wildland fire } \\
\text { management plan, incorporate the community surrounding } \\
\text { BNL with the various elements. Existing methods can be } \\
\text { used with the addition of local fire departments and response } \\
\text { units. }\end{array}$ & $7 / 01 / 01$ & Joe Levesque, EM \\
\hline $\begin{array}{l}\text { Action Item \#8: ATS } 361.2 .8 \text { Request funding to establish a } \\
\text { routine program for sampling vegetation for radiological } \\
\text { uptake should be investigate ensure areas of significant } \\
\text { radiological content have not been overlooked. }\end{array}$ & $4 / 20 / 01$ & Tim Green, ES \\
\hline
\end{tabular}




\section{Introduction}

\section{Purpose and scope:}

1) Identify BNL operations threatened by wildland fires.

2) Determine potential severity of a wildland fire at BNL.

3) Identify safeguards and management systems to mitigate the risk.

4) Identify deficiencies and suggest improvements.

\section{The assessment methodologies used in this report are as follows:}

1) Identify operations along the wildland fire interface.

2) Group the facilities into similar units for the analysis.

3) Evaluate the hazards for each group area using a wildland fire model,

4) Evaluate the protective features when weighted against the hazards

5) Develop "needs" for future actions.

\section{Background for the Wildland Fire Concerns}

Large and destructive wildland fires have occurred nationwide over the past years. In calendar year 2000, wildland fires at three facilities directly threatened DOE operations. Los Alamos was shutdown for 13 days, burned 7,500 acres of land, and destroyed 45 structures. Hanford had portions of the site evacuated for 3 days and burned $40 \%$ of the land (over 400,000 acres). The potentials for large-scale damage from wildland fire threats were clearly demonstrated by these incidents. Despite the potential for devastation, these fires at DOE facilities have shown that proper proactive wildland management techniques can minimize fire impact.

BNL occupies 5,265 acres, of which only 1,650 acres are developed (see Appendix A for a site map). There is a real threat for a devastating fire either originating on BNL property or traveling onto BNL property from the adjacent forested areas. BNL's 3,000 acres of Pine Barrens Region is an integral part of the 100,000 acres of Central Pine Barrens Region on Long Island. Historically BNL has experienced approximately one significant brush fire every five years (significant is defined as a fire large enough to activate BNL mutual aid plan with local fire departments). In CY $2000 \mathrm{BNL}$ experienced four wildland fires requiring response from offsite agencies. The forest areas of BNL are mature with high fuel loading per acre. With high fuel loads, fires are hotter, spread further, and are less likely to be controlled. A wildland fire is a direct threat to structures along the interface between wildland and urban developments. BNL has many significant facilities along the wildland interface zone, not the least being RHIC, AGS, the housing area, Child Developmental Center, the former Hazardous Waste Management Facility, Site Power Lines, and the Sewage Treatment Plant. 
Not only can fires endanger on-site programs, but also the reverse can happen. An on-site fire can sweep to the north and east destroying property of our neighbors. Such an event would cause long term damage to the relations with local communities. The DOE site at Hanford is still encountering public ire several months after their wildland fire. Likewise, fires originating off-site are a concern as they can sweep into BNL with the same devastating results.

\section{Elements Effecting Wildland Fire Severity}

The following sections review and define the elements that effect the severity of a potential wildland fire on BNL property.

\section{Fuels}

Brookhaven National Laboratory (BNL) is a 5,265-acre site centrally located on New York's Long Island. The Lab is located approximately 60 miles east of New York City and 60 miles west of Montauk Point. Approximately 500 acres of the site are developed, leaving approximately 4,700 acres of wooded wildland.

William Floyd Parkway borders BNL to the west. The parkway is a four lane highway with a center median. To the south of BNL is the six-lane Long Island Expressway with a two lane service road. Both are substantial firebreaks. The remaining perimeter of BNL's wildlands is continuous with the surrounding forested areas. A fire originating onsite can spread offsite into the nearby homes and communities. Likewise, a fire offsite can travel onsite and threaten onsite operations.

The wildland terrain is primarily forested with a variety of conifers and hardwood species. The forested wildlands are mature and heavily populated. A thick ground cover of organic material (litter) is present from years of undisturbed growth. Also present is normal occurrence of "down and dead" timber. The thick layer of litter and down and dead timber increases the severity of the possible fire by providing a "ladder of combustibles" from the floor to the canopy layer of trees. While the forested areas are not populated, the area is frequently used for recreational activities such as hiking, horseback riding, bicycle riding, and hunting.

\section{Weather}

Long Island weather affords a good growing season. Normally, moisture content of the vegetation remains high, thereby keeping the fire severity index "moderate" to "high." Approximately once every ten years the growing season is exceedingly dry and escalates the fire hazards into the "extreme" range (highest rating by NFPA 299). Under the extreme conditions, the vegetation is easily ignited and will propagate flame rapidly. The wildland fire season is a threat on Long Island from May to November. 


\title{
Wind
}

During the Wildland fire season, the wind speeds are "low" to "moderate." Long Island does not face $40 \mathrm{mph}$ to 50-mph winds with any regularity, except during stormy weather (not concurrent with wildland fire concerns). During a typical summer day, winds start from the north in the morning and shift to the south by mid day. This shore effect phenomenon is due to the large bodies of water to Long Island north and south. Nominal wind direction is to the northwest ( $25 \%$ of the time) and south by southwest ( $20 \%$ of the time). The wind direction and intensity affects which facilities are more likely to be exposed to a fire and the intensity of the fire.

The following is a wind rose from the 1999 Site Environmental report showing BNL wind patterns.

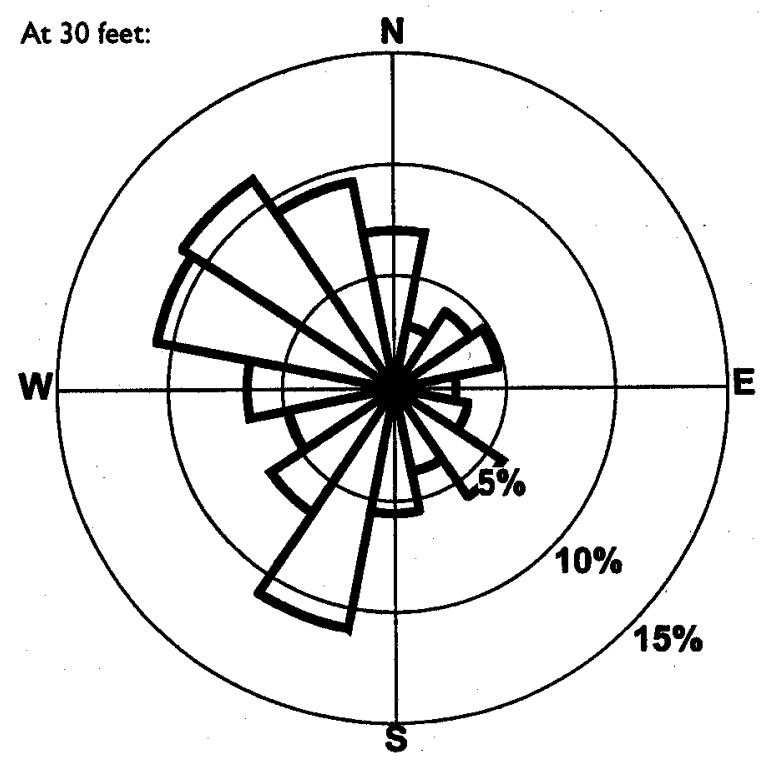

\begin{abstract}
Explanation: The arrows formed by the wedges indicate wind direction. Each concentric circle represents a $5 \%$ frequency. The wind direction was measured at heights of 30 feet and 300 feet. For example, this diagram indicates that the predominant wind direction at 30 feet in 1999 was from the northwest.
\end{abstract}

\section{Topography}

BNL property and the adjacent wildland are relatively flat. Slopes less than $10 \%$ are the rule. The wildland elevations range from $50 \mathrm{ft}$. above mean sea level to $80 \mathrm{ft}$. above mean sea level. Low slopes decrease the severity of a possible fire. Localized hills and ridges do exist. They are examined as part of the "defensible space" evaluations, rather than a global risk factor. 


\section{Risk Evaluation System and Methodology}

This report uses the National Fire Protection Association's (NFPA) "Standard for Protection of Life and Property from Wildfire," NFPA 2991997 Edition to evaluate BNL's Wildland Fire Risk. The NFPA Standard is one of the nationally recognized methods of performing an assessment of the wildland fire hazard to a community. NFPA 299 is part of the National Fire Codes, which are contractually required documents in the operating contract between Brookhaven Science Associates (operators of BNL for DOE) and DOE.

The NFPA 299 scope as follows:

"This standard presents the minimum planning, construction, maintenance, education and management elements for the protection of life and property from wildfire."

As previously alluded to, the methodology used to evaluate this risk is to:

1. Define the areas on-site that are Wildland/Facility interfaces. Woods border much of the site. For the purpose of this analysis at BNL, a facility is considered within the Wildland Interface if the structure or operation outside of the structure is within $100 \mathrm{ft}$. wildlands. Lawns and unpaved roads are not counted as part of the wildland areas.

2. Group facilities into logical "Wildland Facility Interface Zones." This was a subjective grouping of facilities based on location and similarity of use, construction and wildland exposures. Facilities included other structures besides buildings, such as utilities.

3. Determine the severity of the wildland fire hazard for each logical "Wildland Facility Interface Zones" using the risk model within NFPA299. NFPA 299 worksheets were filled out for each defined zone. In the work sheets, several items have to be interpreted for application at BNL. "Average Lot Size" was interpreted to mean the density of structures in the area. Street signs that were plastic instead of reflectorized were given partial credit.

4. Evaluate the adequacy of protective measures and management systems. NFPA 299 itemizes several support systems used to mitigate wildland fire hazards. These systems were expanded on from NFPA 299. They are defined and evaluated in the latter part of the report.

5. Develop needs for future actions. Throughout this report, issues and needed improvements were identified. Items resulting in "action items" are being entered into the BNL Directorate Level Action Tracking System (ATS) to ensure completion. A list of the action items has been extracted from the analysis section and provided in Section II of this report. 


\section{Defining the Wildland/Facility Interface Zones}

In order to perform the wildland fire severity analysis, various areas on-site were grouped based on similar construction, facility function, and wildland characteristics. The following "Wildland Facility Interface Zones" were chosen.

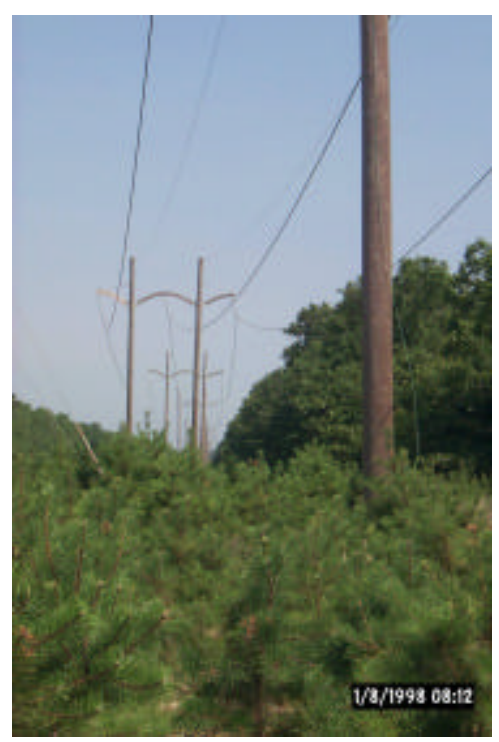

Example of overhead power supply line route
Site Power Supply Lines - Two sets of overhead power lines provide electricity to BNL from the Long Island Power Authority's power grid. The supply lines are designated as Primary and Alternate feeders. The lines traverse two and one half miles of wildland on the east side of the site. They terminate at independent substations. Neither line is able to supply BNL with the full electrical load required to run all the larger experimental machines. The power lines are on wooden poles. Cables have electrically insulating plastic jackets. Shown to the left is the east end of the Sixth Ave power lines and East Fire Break at the Long Island Power Authority's Right of Way.

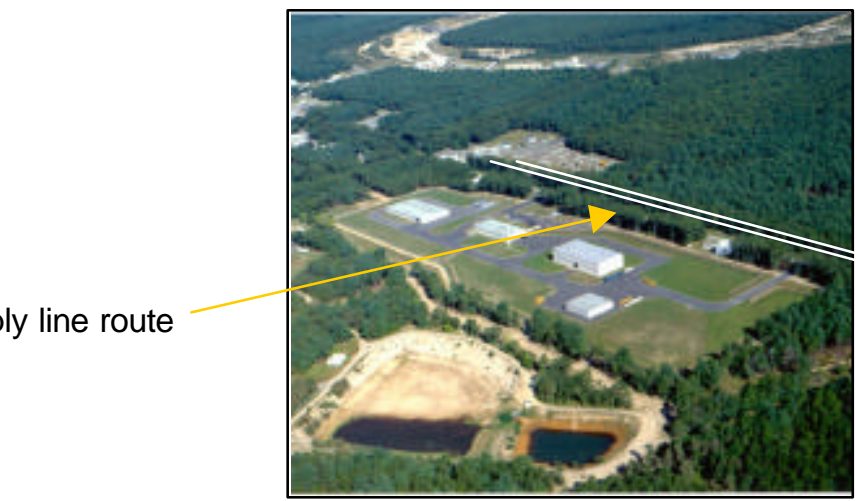

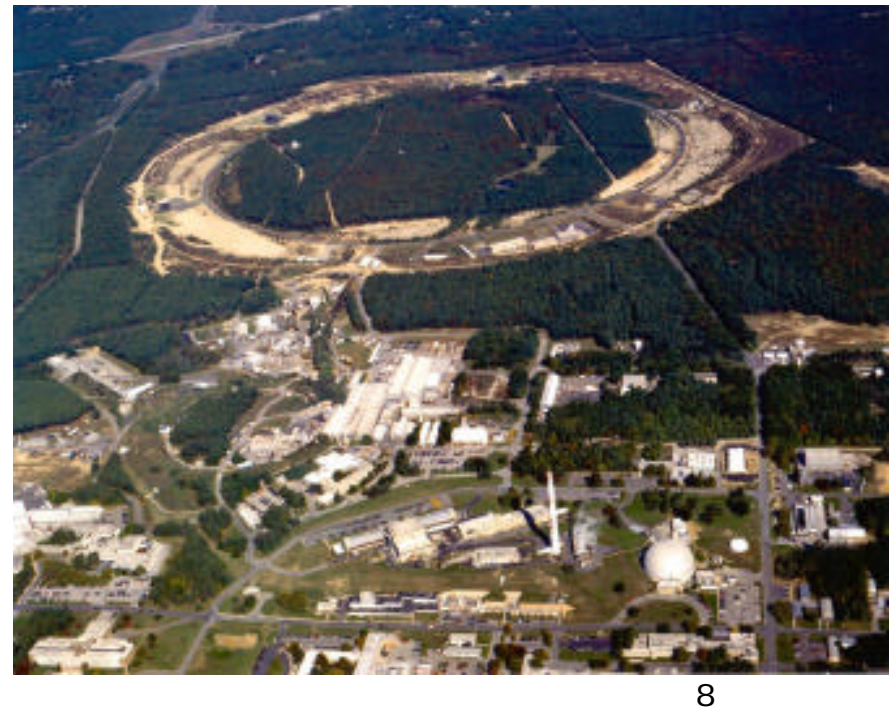

RHIC Complex - The Northern part of BNL is predominately occupied by accelerator facilities. Most predominate is the $\mathrm{RHIC}$ accelerator buildings. The tunnels, collision halls with detectors and support buildings are nested in the wildland of BNL's northern property. Typically, the buildings are constructed using noncombustible walls and roofs. The north edge of RHIC touches the Peconic River headwaters and is less than $1 / 4$ mile from private residences. The RHIC Ring (circular area) is shown during initial construction. 

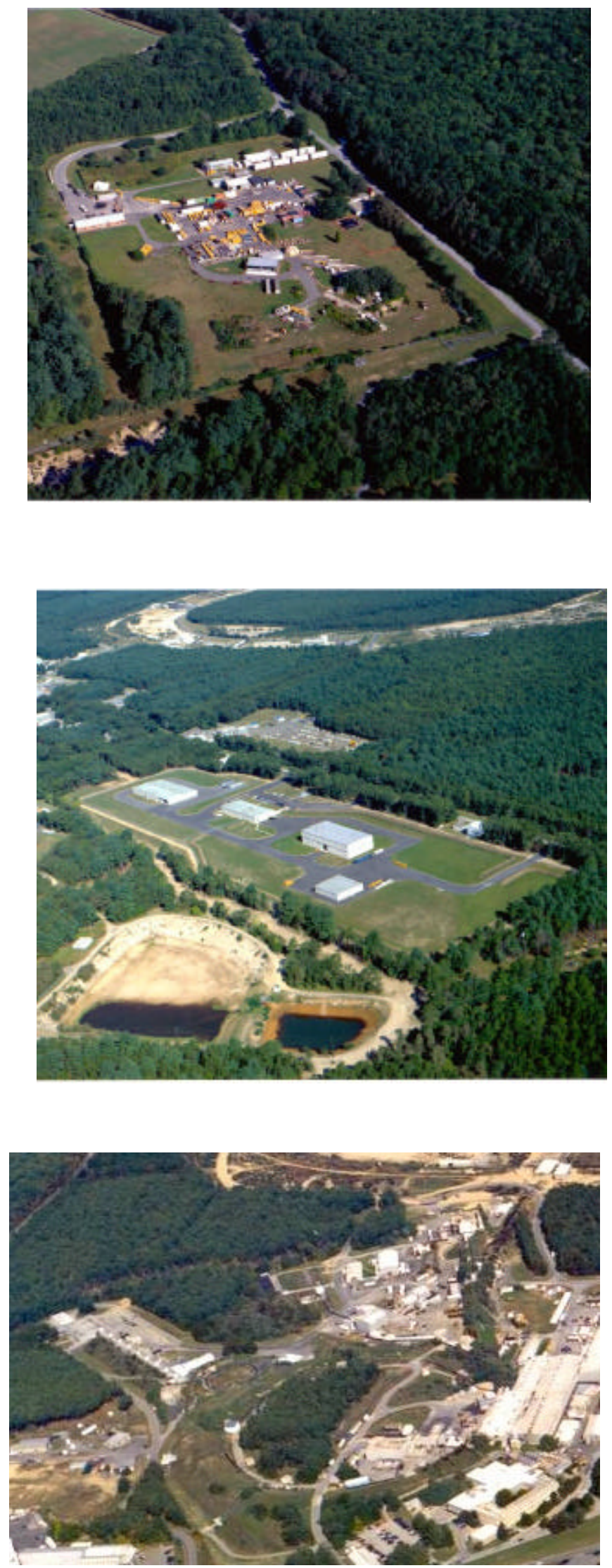

Former Hazardous Waste Management - A cluster of buildings located in the southwest portion of BNL, currently undergoing remediation and decommissioning. Formerly the facilities were used for the storage and disposition of radiological and hazardous waste. Legacy materials currently exists. The facilities are constructed of noncombustible materials. Detailed information is available at: http://www.oer.dir.bnl.gov/soils/ou1/ou1rira.html

\section{New Waste Management} Facility - A 10 acre complex of building handling current inventories of hazardous waste and radiological materials. Facilities are constructed of noncombustible materials, provided with clear defensible areas.

\section{AGS/LINAC Buildings - $A$} complex of facilities at the north west section of BNL supporting the major accelerator. Construction is typically insulated metal skinned buildings with steel frames. Cable trays (with essential power, control and data cables) and cooling towers are the primary components vulnerable to fire damage. 


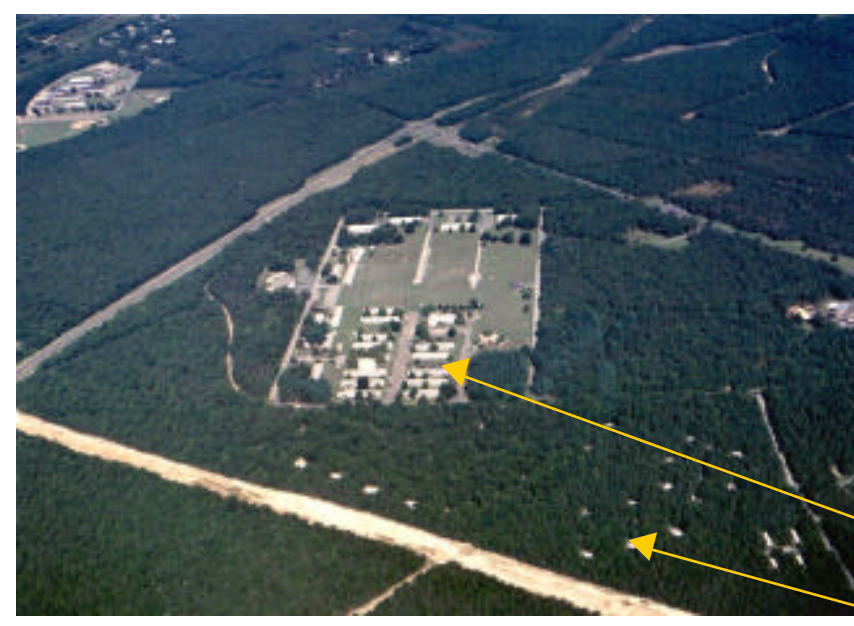

Apartment/Cottage Area - A complex of single story wooden residences, used to house single and multiple families, including juveniles. The area includes 30 singlefamily cottages, deeply embedded in the woods. The facilities include daycare, laundry and playgrounds. Class $A$ roofing materials are used.

Apartments

Summer Cottages

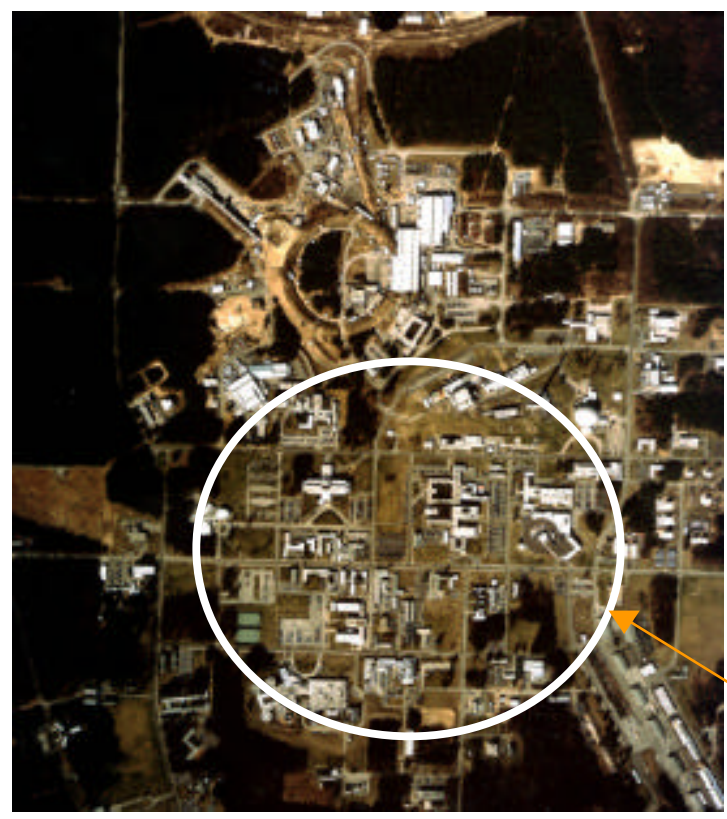

General Perimeter of BNL Central Core Buildings ${ }^{4}-$ General catchall list of buildings used to evaluate the majority of buildings on-site. Typically, these facilities have "fingers" of vegetation that extend near the facility. There are no major exposures from these isolated island of fuels and there are ample access roads. Wildland fires originating in these regions will not have the ability to develop into large area fires due to the restricted amount of vegetation. However, localized fires can cause localized damage to facilities.

${ }^{4}$ These facilities are included for comparison. They are technically outside the interface region. 


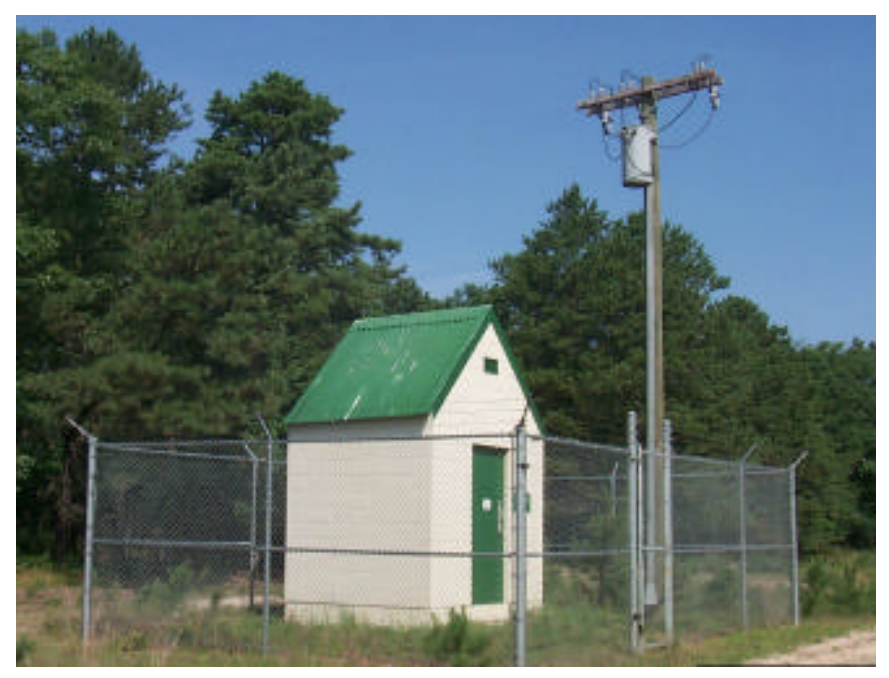

Miscellaneous Small Monitoring and Well Houses - Typically located within the wildland region, these remote facilities are used to house environmental monitoring equipment. They are constructed of heavy noncombustible walls and noncombustible roofs. Value of the structure is minimal. Samples taken from these facilities are used in the BNL Environmental Monitoring Program.

\section{Analysis}

The Wildland Fire Severity Index rating is based on vegetation hazards. Some wood species burn more intensely than others. The Wildland Severity Rating is assigned to a section of woods by matching descriptions of vegetation to one contained in the model from the NFPA 299. Being a typical Northeast Pine-Oak and Oak-Pine type forest, the highest rating on-site was "Moderate" (see Appendix B for worksheets).

Another element in the analysis is the Building Material Combustibility. Most building on-site have non-combustible roof (UL Class A) and non-combustible walls (insulated metal skin, concrete block). This general category is has the Building Material Combustibility rating of "low." The exceptions are:

- Apartments (wood frame, vinyl siding over asbestos shingles, UL Class A roof),

- Cottages (wood frame, wood exterior, UL Class A roof),

- Bldg. 51 (wood frame, vinyl siding over asbestos shingles, UL Class A roof),

- Bldg. 170 (wood frame, vinyl siding over asbestos shingles, UL Class A roof),

- Bldg. 244 (wood frame, asbestos shingles, UL Class A roof), and

- Bldg. 348 (wood frame, vinyl siding over asbestos shingles, UL Class A roof).

These exceptions have "high" Building Material Combustibility ratings.

The next factor is the terrain. As stated earlier the terrain is predominately level across the BNL site. The Slope Hazard Index is therefore "low" (0-20 percentage). 
Based on a fire severity rating of "moderate", the slope rating of "low", the Building Material Combustibility index becomes the predominate element influencing the overall rating's change from "moderate" to "high."

The following table summaries the results of the NFPA 299 worksheets:

\begin{tabular}{|l|c|c|}
\hline \multicolumn{1}{|c|}{ Wildland Fire Area } & Points Assigned & Hazard Rating \\
\hline \hline Site Power Supply Lines & 39 & Low \\
\hline RHIC Complex & 38 & Low \\
\hline Former Hazardous Waste Management & 49 & Low \\
\hline New Waste Management Facility & 29 & Low \\
\hline AGS/LINAC Buildings & 35 & low \\
\hline Apartment/Cottage Area & 51 & Moderate \\
\hline General Perimeter of BNL Central Core Buildings & 51 & Low \\
\hline Miscellaneous Small Monitoring and Well Houses & 23 & Moderate \\
\hline
\end{tabular}

${ }^{5}$ These facilities are included for comparison. They are technically outside the interface region. 


\section{Resulting Protective Criteria}

The following protective actions represent minimum requirements and are contained in Table A-3-2(c) of NFPA 299 for "Defensible Space Clearing and Structural Summary ":

\begin{tabular}{|l|l|l|}
\hline \multicolumn{1}{|c|}{ Low Hazard Rating } & \multicolumn{1}{|c|}{ Moderate Hazard Rating } & \multicolumn{1}{|c|}{ High Hazard Rating } \\
\hline \hline $30 \mathrm{ft}(9.14 \mathrm{~m})$ clearance & $30 \mathrm{ft}(9.4 \mathrm{~m})$ irrigated & $30 \mathrm{ft}(9.4 \mathrm{~m})$ irrigated \\
\hline Class C roof & Class B roof & Class A roof \\
\hline $\begin{array}{l}\text { No portion of trees or other } \\
\text { vegetation within } 10 \mathrm{ft}(3.05 \mathrm{~m}) \\
\text { of chimney outlets }\end{array}$ & $\begin{array}{l}\text { Noncombustible siding/wood } \\
\text { decks }\end{array}$ & $100 \mathrm{ft}(30.48 \mathrm{~m})$ fuel treatment \\
\hline $\begin{array}{l}\text { Trees within defensible space } \\
\text { shall be pruned to minimize } \\
\text { ladder fuels }\end{array}$ & $\begin{array}{l}\text { Selected fire- resistant trees } \\
\text { within } 30 \mathrm{ft}(9.14 \mathrm{~m}) \text { of } \\
\text { structures }\end{array}$ & $\begin{array}{l}\text { Noncombustible siding/decks } \\
\text { and boxed eaves }\end{array}$ \\
\hline & $\begin{array}{l}\text { Trees within defensible space } \\
\text { shall be pruned to minimize } \\
\text { ladder fuels }\end{array}$ & $\begin{array}{l}\text { Selected fire-resistant trees } \\
\text { within } 30 \mathrm{ft} \text { (9.14 } \mathrm{m}) \text { of } \\
\text { structures }\end{array}$ \\
\hline & $\begin{array}{l}\text { No portion of trees or other } \\
\text { vegetation within } 10 \mathrm{ft} \text { of } \\
\text { chimney outlets }\end{array}$ & $\begin{array}{l}\text { Selected thinning of trees and } \\
\text { shrubs }\end{array}$ \\
\hline & $\begin{array}{l}\text { Trees within defensible space } \\
\text { shall be pruned to minimize } \\
\text { ladder fuels }\end{array}$ \\
\hline
\end{tabular}

A general tour of the site was conducted as part of this report. However, a detailed examination of the facilities was not preformed. This detailed analysis will be conducted as part of the commitment to incorporate wildland fire protection measures into FUA for facilities in the wildland interface zone (ATS 361.1.2). 


\section{Protective Features and Management Systems}

The following section reviews the various Management Systems in place to provided protection and/or control of wildland fires.

\section{Fire Response}

BNL Fire/Rescue Group is a full time, paid Department. Normal staffing is eight firefighters and one officer per shift. Minimum staffing is six Fighters and one Fire Officer. The firefighters are trained in structural fire fighting and wildland fire fighting (Suffolk County's wildland fire fighting curriculum is used).

For the initial response to wildland fires, the following BNL equipment is available:

- One 6 wheel drive Brush Truck with a 500 gallon pump and 1,000 gallons of water for off road operations.

- Two $1500 \mathrm{gpm}$ Class A Fire Engines with 500 gallons of water each, and over 1500 feet of hose each ( $2 \frac{1}{2} 2^{\prime \prime}, 3 "$, and $5 "$ hose).

- Four wheel drive Incident Command Vehicle

- $\quad$ D7 bulldozer for clearing firebreaks (Plant Engineering).

The following external assistance is available:

- BNL is a participating member of the Suffolk County Mutual Aid Agreement. For wildland fires, over one hundred departments and their equipment are available to assist BNL in controlling a fire. Over twenty-brush truck and additional supporting equipment can be summoned with 45 minutes

- Suffolk County Police, Air National Guard, Army Aviation, and US Coast Guard can provide a helicopter for aerial recognizance.

- Town of Brookhaven and Riverhead can provide bulldozers and repair mechanics.

- New York State Forest Rangers are available for extended fire fighting operations.

This is considered an adequate response. However, the DOE required "fire protection baseline needs assessment "should be updated to incorporate this wildland aspects. This commitment was already made to DOE under the "Wildland Fire Safety Enhancement Plan" (ATS 361.1.5).

Massive wildland fire pose special emergency planning issues. Preparedness for such events should be documents in procedures. In the BNL Wildland Fire Safety Enhancement Action Plan, a commitment to DOE was made to finalize the Wildland Fire Response procedure for BNL Fire/Rescue (ATS 361.1.8). 


\section{Communications}

All BNL emergency response vehicles are equipped with Suffolk County fire radio frequencies for direct communication. Communication is also available through cellular telephones and land-based telephones. With exception of the cellular telephones, these have been proven reliable means of communications during emergencies.

\section{Water Supplies}

BNL has it own water supply system separate from the Suffolk County Water Authority. Multiple deep-water wells pump directly into the system. Wells are provided with electric drives. Several key wells have LP powered backup drivers. Two elevated storage tanks stabilize the water pressure and provide reserves. Water supply mains are well grided and equipped with fire hydrants. The distribution system reaches every major building (excluding are the remote monitoring buildings). This enables wildland fire operations to be within $3 / 4$ of a mile of water supplies.

Refill time for fire fighting equipment will be less than 15 minutes. Outside fire departments can provide tanker trucks or establish relay systems with Class A fire pumpers in case of water system failures. Drafting water supplies are not possible since there are no significant bodies of water. Drafting from the ponds in the area will also threaten tiger salamander populations (a New York State endangered species). Water supplies are considered adequate and reliable.

\section{Access Roads}

The site has a network of roads. The center portion of site and most major facilities are accessed through two lane paved roadways (designed as "roads," "avenues," or "streets"). Remote portions of the site have "fire breaks" and "access roads."

BNL's intentions are to maintain "fire breaks" as 60 foot wide roads, free of combustible vegetation. "Access roads" are maintained, two lane roads in the context of NFPA 299. The formalization of maintenance on these road will be provided in the Subject Area on Wildlands. This development of this Subject Area was committed to as part of the BNL Wildland Fire Safety Enhance Plan and is being tracked under ATS 361.1.6.

In the more remote areas, roadways decrease to single lane dirt roads. Most often, remote facilities have bluestone-covered access roads. Roads in the wildland areas are typically hard packed dirt. BNL access roads into the wildland are sufficient to allow access by Class $A$ pumper during dry spells (the highest hazard times). These access roads allow the brush truck to come within $1 / 4$ mile of any wildland area without making entry into the woods. The exceptions are the eastern most woods. A former north to south running road between the power line right of way and North Street has grown over. This road nearly is impassable by fire response vehicles.

Action Item \#1: To allow access to the North East region of the BNL Pine Barren, the access road running north to south between the east power line's right of way and North Street should be made passable. (ATS 361.2.1)

The fire breaks, access roads, paths, and ways have not been identified in any formal means (maps or by road signs). The use of GPS systems has not yet been implemented within the fire service on Long Island. These factors have a potential for creating operational delays with fire fighting efforts being unable to locate fires or communicate locations accurately. 
Action Item \# 2: Identify required firebreaks access roads, paths, and ways to provide consistent nomenclature for normal operations (PE, ERD, Fire/Rescue), outside fire department operations, and operations of the new nature preserve. As a guideline, roads should allow access within $1 / 4$ mile any forested area. (ATS 361.2.2)

Action Item \#3: Establish a policy to provide identification of Firebreaks and Access Roads with street signs meeting NFPA 299. (ATS 361.2.3)

Access roads are to be arranged so that "dead end" paths do not exceed 300 feet. This minimizes the chance for occupants becoming trapped in an area as fire blocks off the sole escape route. The Summer Cottage Area has dead end paths that exceed three hundred feet (NFPA 299 requirement).

Action Item \# 4: A second means of egress is needed for the Summer Cottage Area (Mendel and Aston Lanes). (ATS 361.2.4)

The site as a whole has two primary exits, both leading to the west of BNL on William Floyd Parkway. It is conceivable that an incident from the west could be block off or create extremely difficult egress from BNL's two western gates, which lead to William Floyd Parkway.

Action Item \# 5: Evaluate the need for an eastern emergency exit from the BNL site. The most viable solution maybe to enhance the road from Brookhaven Avenue by Bldg. 445 to the South East exit to North Street. (ATS 361.2.5)

\section{BNL's Internal Community Awareness}

BNL has an established method of communicating requirements placed on its facilities and to its workers. Operational envelopes for BNL facilities are defined within Facility Use Agreements (FUA). Currently FUAs do not identify facilities that are along the Wildland/Facility Interface Zone. As part of the corrective actions listed in the BNL Wildland Fire Safety Enhancement Plan sent to DOE, a commitment has been made to incorporate required wildland fire protection elements in to the FUAs (ATS 361.1.2).

The Standards Based Management System (SBMS) is used site-wide to establish criteria for operations and worker behavior. This system currently does not have topics which include wildland issues (access roads, fire breaks, minimum building construction standards, roof coverings, defensible space, vegetation selection, controlled burns for vegetation reduction, extreme fire hazard precautions). As part of the corrective actions listed in the BNL Wildland Fire Safety Enhancement Plan sent to DOE, a commitment has been made for the development of a "Wildland" Subject Area (ATS 361.1.6).

Action Item \# 6: BNL sponsored camping and softball activities have potential ignition sources for a wildland fire. Safeguards should be developed and implemented for camping, camp fires, and BBQs following National Fire Code requirements. (ATS 361.2.6)

\section{External Community Awareness}

Wildland fire risks have not been explored with the external community. The Central Pine Barrens Commission is piloting a Fire Protection Assessment. This will provide an excellent opportunity to involve the surrounding communities. As other activities progress, involvement of outside fire departments and BNL Community Relations and Public Affairs will increase. 
Action Item \# 7: While developing a wildland fire management plan, incorporate the community surrounding BNL with the various elements. Existing methods can be used with the addition of local fire departments and response units. (ATS 361.2.7)

\section{Wildland Fires as a Means of Radiological Release}

Given a wildland fire excellent transport capability, the potential for transport of smoke containing radiological material was examined. Based on past BNL operations there are several sites that have been characterized by the Environmental Restoration Division (ERD) as facilities with ground contamination (Appendix C). The levels of soil contamination limit the uptake of vegetation. The quantities that could be released in case of a wildland fire are in the environmental levels of exposure to on-site and off-site personnel. The available calculations were preformed as the result of an emergency drill excise and should be refined and formalized. As part of the corrective actions listed in the BNL Wildland Fire Safety Enhancement Plan sent to DOE, a commitment has been made for these calculations to be complete (ATS 361.1.1).

Given BNL use of radilonuclides, a request was made for site wide sampling of vegetation for radiological. A comprehensive examination of vegetation has not been performed.

Action Item \# 8: Request funding to Establish a routine program for sampling vegetation for radiological uptake should be investigate ensure areas of significant radiological content have not overlooked. (ATS 361.2.1) 


\section{Appendix A Site Map}

The following site map shows the wildland areas shaded in light green.

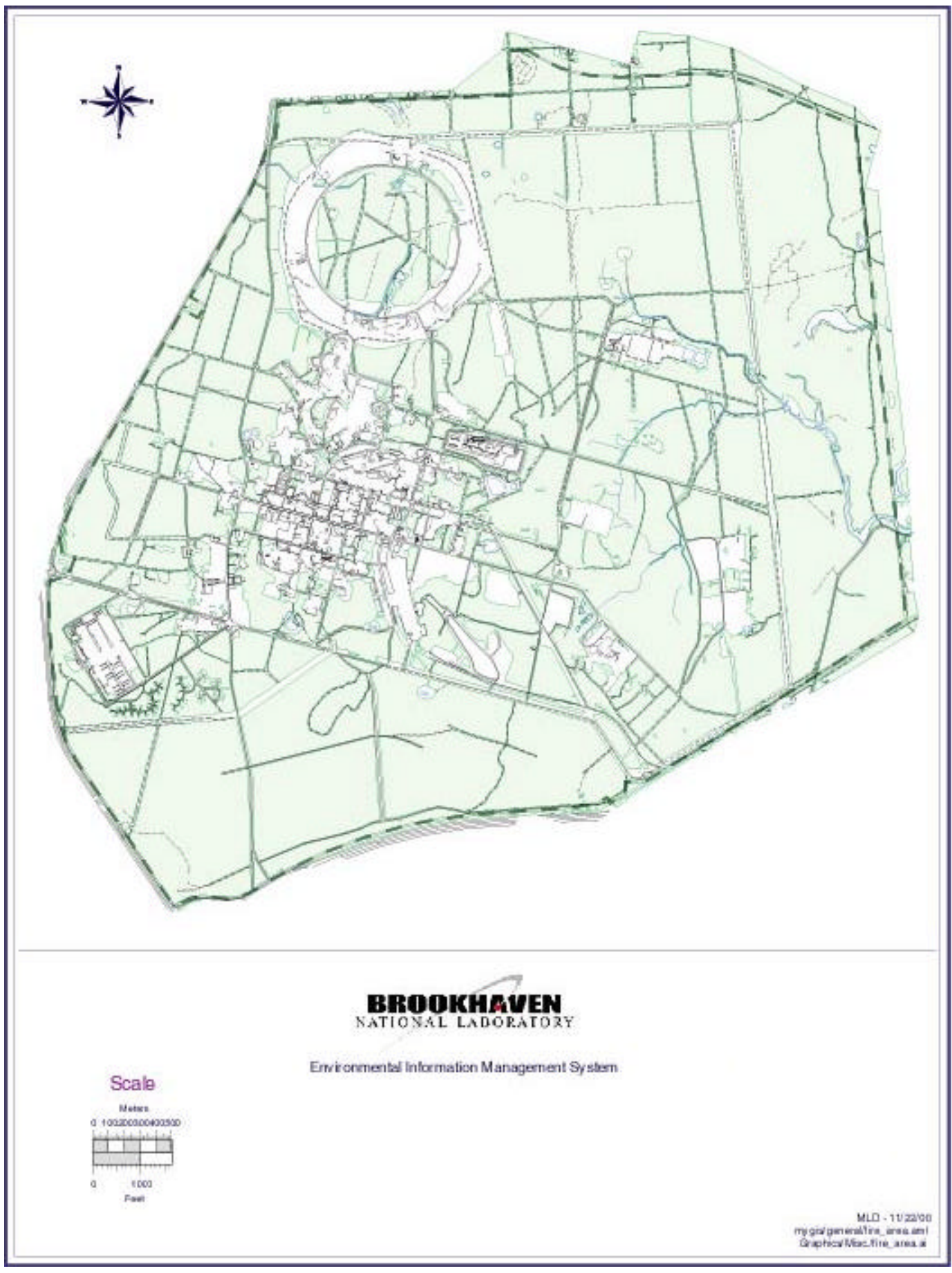




\section{Appendix B}

\section{Wildland Hazard Severity Checklist Worksheets}

NFPA 299, Table A-3-2(a) Wildfire Hazard Severity Form Checklist

\section{Site Electrical Power Supply Lines}

Element

Points

A. Subdivision Design

1. Ingress and egress

Two or more, primary roads

One road, primary route

One way in/out

$1 \underline{x}$

3

5

2. Primary road width

Minimum of $20 \mathrm{ft}(6.1 \mathrm{~m})$

Less than $20 \mathrm{ft}(6.1 \mathrm{~m})$

$1 \underline{X}$

3

3. Road accessibility

Smooth road, grade $<5 \%$

Rough road, grade $>5 \%$

Other

1

$3 \bar{x}$

5

4. Secondary road terminus

Loop roads, cul-de-sacs

Outside radius $>50 \mathrm{ft}(15.2 \mathrm{~m})$

Outside radius $<50 \mathrm{ft}(15.2 \mathrm{~m})$

$1 \underline{X}$

Cul-de-sac turnaround

Dead-end roads $<200 \mathrm{ft}(61 \mathrm{~m})$

3

Dead-end roads $>200 \mathrm{ft}(61 \mathrm{~m})$

3

5

5. Average lot size

More than 10 acres (4.1 ha)

Between 1 and 10 acres (0.4-4.1 ha)

Less than 1 acre (0.4 ha)

$1 \underline{X}$

$3-$

6. Street signs

Present [4 in. $(10.2 \mathrm{~cm})$ in size and reflectorized]

Not present

1

$5 \underline{x}$

B. Vegetation (Fuel Models)

1. NFDRS fuel models

Light (grasses, forbs, sawgrasses, and tundra)

Fuel models A, C, L, N, S, and T

Medium (light brush and small trees)

1

$5 \underline{X}$ 
Fuel models $D, E, F, H, P, Q$, and $U$

Heavy (dense brush, timber, and hardwoods) 10

Fuel models B, G, and O

Slash (timber harvesting residue) 10

Fuel models $\mathrm{J}, \mathrm{K}$, and $\mathrm{L}$

2. Defensible space

More than $100 \mathrm{ft}(30.48 \mathrm{~m})$ of treatment from buildings 1

30-70 ft (9.1-21.3 $\mathrm{m})$ of treatment from buildings

No defensible space treatment

5

$10 \underline{X}$

C. Topography

1. Slope

Less than $9 \%$

Between 10 and $20 \%$

Between 21 and $30 \%$

Between 31 and $40 \%$

Greater than $41 \%$

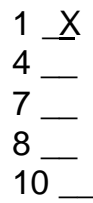

D. Additional Rating Factors

1. Rough topography that contains steep canyons

2

2. Areas with a history of higher fire occurrence than surrounding areas due to special situations such as heavy lightning, railroads, escaped debris burning, arson, etc.

3. Areas that are periodically exposed to unusually severe fire weather and strong dry winds

4

E. Roofing Material

1. Construction material (interpreted to mean resistance to burning brands)

Class A roof

Class B roof

$1 \underline{X}$

Class $C$ roof

Non-rated

5

10

F. Existing Building Construction

1. Materials (predominate) (interpreted to mean resistance side ignition) Noncombustible siding/deck Noncombustible siding/wood deck Combustible siding and deck

G. Available Fire Protection

1. Water source availability (on site)

$500 \mathrm{gpm}(1892.7$ Lpm) hydrants < $1000 \mathrm{ft}(304.8 \mathrm{~m})$ apart Hydrants above or draft site No hydrants or draft site available

2. Water source availability (off site) Sources within 20 min round-trip Sources within 21-45 min round-trip Sources $>46$ min round-trip

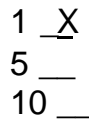


BNL WILDLAND FIRE ASSESSEMENT APRIL 2001

H. Utilities (Gas and Electric)

1. Placement

All underground utilities

1

One underground, one aboveground

All aboveground

$5-\bar{x}$

I. Totals for Subdivision

39 pts. (low)

(Tally up all check-point totals.)

1. Low hazard: < 49 points

2. Moderate hazard: $49-68$ points

3. High hazard: $69-83$ points

4. Extreme hazard: $84+$ points 


\section{RHIC Ring Complex}

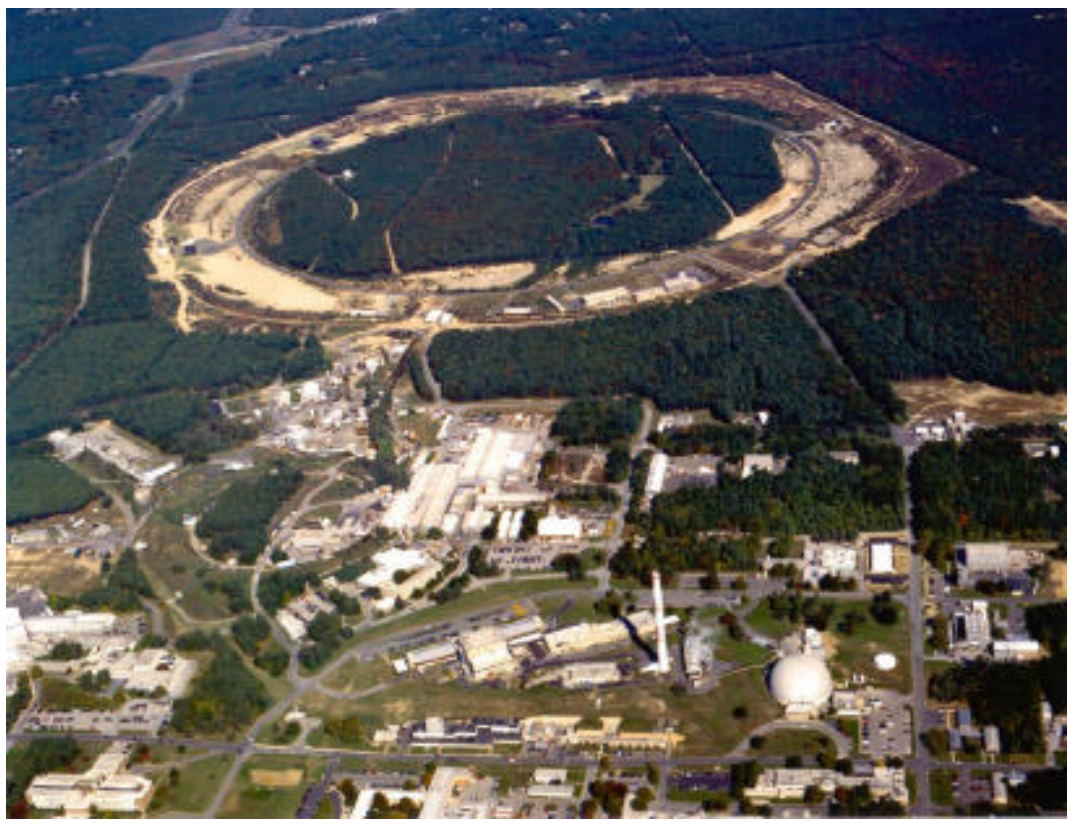

Figure 1 Aerial view of the northern developed part of BNL showing the RHIC Ring.

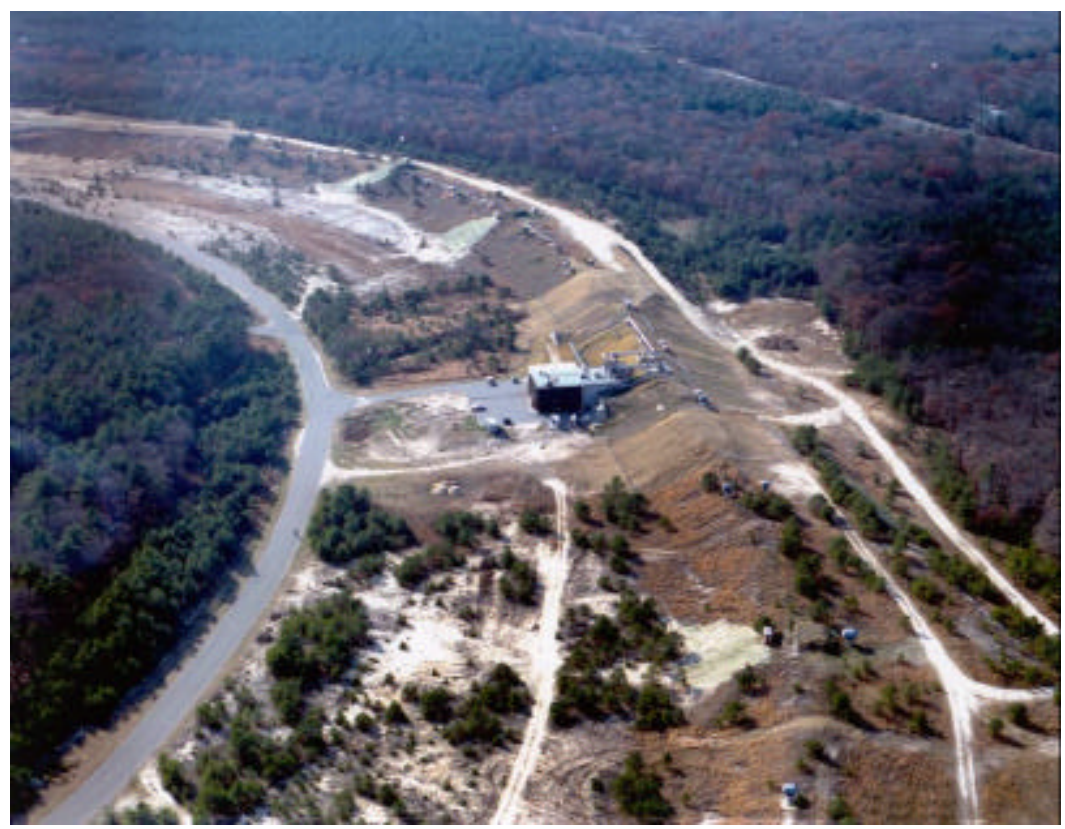

Figure 2 Bldg. 1010 shows the typical vegetation clearance around RHIC Buildings 
Element

A. Subdivision Design

1. Ingress and egress

Two or more, primary roads

One road, primary route

One way in/out

2. Primary road width

Minimum of $20 \mathrm{ft}(6.1 \mathrm{~m})$

Less than $20 \mathrm{ft}(6.1 \mathrm{~m})$

3. Road accessibility

Smooth road, grade $<5 \%$

Rough road, grade $>5 \%$

Other

4. Secondary road terminus

Loop roads, cul-de-sacs

Outside radius $>50 \mathrm{ft}(15.2 \mathrm{~m})$

Outside radius $<50 \mathrm{ft}(15.2 \mathrm{~m})$

Cul-de-sac turnaround

Dead-end roads $<200 \mathrm{ft}(61 \mathrm{~m})$

Dead-end roads $>200 \mathrm{ft}(61 \mathrm{~m})$

5. Average lot size

More than 10 acres (4.1 ha)

Between 1 and 10 acres (0.4-4.1 ha)

Less than 1 acre (0.4 ha)

6. Street signs

Present [4 in. $(10.2 \mathrm{~cm})$ in size and reflectorized]

Not present

B. Vegetation (Fuel Models)

1. NFDRS fuel models

Light (grasses, forbs, sawgrasses, and tundra)

Fuel models A, C, L, N, S, and T

Medium (light brush and small trees)

Fuel models $D, E, F, H, P, Q$, and $U$

Heavy (dense brush, timber, and hardwoods)

Fuel models $\mathrm{J}, \mathrm{K}$, and $\mathrm{L}$

2. Defensible space

More than $100 \mathrm{ft}(30.48 \mathrm{~m})$ of treatment from buildings

$30-70 \mathrm{ft}(9.1-21.3 \mathrm{~m})$ of treatment from buildings

No defensible space treatment

C. Topography

1. Slope

Less than $9 \%$

Between 10 and $20 \%$

Between 21 and 30\%
Points

1

$3 \underline{x}$

5

$1 \underline{x}$

3

1

$3 \underline{x^{6}}$

5

1

$3 \underline{\underline{X}}$

3

5

$1 \underline{x}$

3

5

1

$5 \underline{\underline{X}}_{-}(3$ pts. for plastic)

1

$5 \underline{x}$

10

1

$5 \underline{x}$

10

1

4

$7 \underline{x}$

${ }^{6}$ Blue Stone road for access to Bldg. 1008D,E and grade of road by 1010

${ }^{7}$ Turnarounds at experimental buildings are $<50 \mathrm{ft}$., radius 
Between 31 and $40 \%$

Greater than $41 \%$

8

10

D. Additional Rating Factors

1. Rough topography that contains steep canyons

2. Areas with a history of higher fire occurrence than surrounding areas due to special situations such as heavy lightning, railroads, escaped debris burning, arson, etc.

3. Areas that are periodically exposed to unusually severe fire weather and strong dry winds

2

3

4

E. Roofing Material

1. Construction material

Class A roof

Class B roof

Class $C$ roof

Non-rated

$1 \underline{x}$
$3-$
$5-$
$10-$

F. Existing Building Construction

1. Materials (predominate)

Noncombustible siding/deck

Noncombustible siding/wood deck

Combustible siding and deck

$1 \underline{x}$

5

10

G. Available Fire Protection

1. Water source availability (on site)

$500 \mathrm{gpm}(1892.7 \mathrm{Lpm})$ hydrants < $1000 \mathrm{ft}(304.8 \mathrm{~m})$ apart Hydrants above or draft site

No hydrants or draft site available

$1 \underline{X}$

2

3

2. Water source availability (off site)

Sources within 20 min round-trip

Sources within 21-45 min round-trip

Sources $>46$ min round-trip

$1 \underline{x}$

5

10

H. Utilities (Gas and Electric)

1. Placement

All underground utilities

One underground, one aboveground

All aboveground

1

$3 \underline{\bar{x}}$

5

38 pts. (Low)

I. Totals for Subdivision

(Tally up all check-point totals.)

1. Low hazard: < 49 points

2. Moderate hazard: $49-68$ points

3. High hazard: $69-83$ points

4. Extreme hazard: $84+$ points 


\section{Former Hazardous Waste Management}

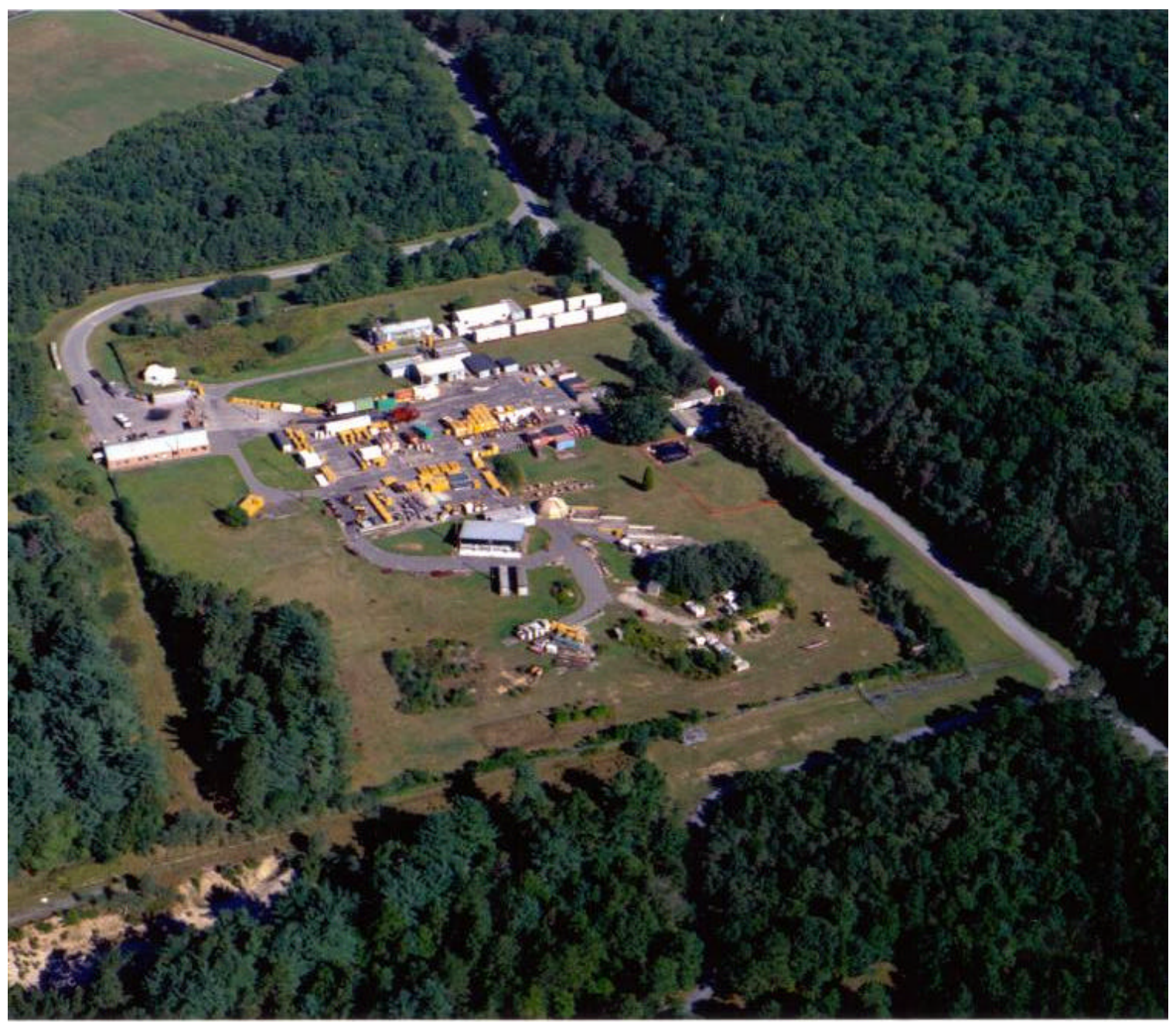

Figure 3 Former Hazardous Waste Management Site, currently undergoing environmental remediation and decommissioning.

Element

A. Subdivision Design

1. Ingress and egress

Two or more, primary roads

One road, primary route

One way in/out

2. Primary road width

Minimum of $20 \mathrm{ft}(6.1 \mathrm{~m})$

Less than $20 \mathrm{ft}(6.1 \mathrm{~m})$

3. Road accessibility

Smooth road, grade $<5 \%$

Rough road, grade $>5 \%$

Other
Points

1

$3 \underline{\bar{x}}$

$5 \underline{x}$

$1 \underline{x}$

3

$1 \underline{x}$

3

5 
4. Secondary road terminus

Loop roads, cul-de-sacs

Outside radius $>50 \mathrm{ft}(15.2 \mathrm{~m})$

Outside radius $<50 \mathrm{ft}(15.2 \mathrm{~m})$

$1 \underline{x}$

3

Cul-de-sac turnaround

Dead-end roads $<200 \mathrm{ft}(61 \mathrm{~m})$

Dead-end roads $>200 \mathrm{ft}(61 \mathrm{~m})$

3

$5 \underline{x}$

5. Average lot size

More than 10 acres (4.1 ha)

Between 1 and 10 acres (0.4-4.1 ha)

Less than 1 acre (0.4 ha)

6. Street signs

Present [4 in. $(10.2 \mathrm{~cm})$ in size and reflectorized]

Not present

$5 \overline{\underline{X}}$

B. Vegetation (Fuel Models)

1. NFDRS fuel models

Light (grasses, forbs, sawgrasses, and tundra)

Fuel models A, C, L, N, S, and T

Medium (light brush and small trees)

Fuel models D, E, F, H, P, Q, and U

Heavy (dense brush, timber, and hardwoods)

Fuel models B, G, and O

Slash (timber harvesting residue)

1

3

Fuel models $\mathrm{J}, \mathrm{K}$, and $\mathrm{L}$

2. Defensible space

More than $100 \mathrm{ft}(30.48 \mathrm{~m})$ of treatment from buildings

30-70 $\mathrm{ft}(9.1-21.3 \mathrm{~m})$ of treatment from buildings

No defensible space treatment

$10 \underline{x}$

C. Topography

1. Slope

Less than $9 \%$

Between 10 and $20 \%$

Between 21 and $30 \%$

Between 31 and $40 \%$

Greater than $41 \%$

$1 \underline{x}$

4

7

8

10

D. Additional Rating Factors

1. Rough topography that contains steep canyons

2. Areas with a history of higher fire occurrence than surrounding areas due to special situations such as heavy lightning, railroads, escaped debris burning, arson, etc.

3. Areas that are periodically exposed to unusually severe fire weather and strong dry winds

E. Roofing Material

1. Construction material

Class A roof

Class B roof

Class $C$ roof

Non-rated
1

5

1

$5 \underline{x}$

10

10

-

2

3

4

$1 \underline{x}-$
$3-$
$5-$ 
F. Existing Building Construction

1. Materials (predominate)

Noncombustible siding/deck

Noncombustible siding/wood deck

Combustible siding and deck

$1 \underline{X}$

5

10

G. Available Fire Protection

1. Water source availability (on site)

500 gpm (1892.7 Lpm) hydrants < $1000 \mathrm{ft}(304.8 \mathrm{~m})$ apart Hydrants above or draft site

No hydrants or draft site available

$1 \underline{x}$

2

3

2. Water source availability (off site)

Sources within 20 min round-trip

Sources within 21-45 min round-trip

$1 \underline{x}$

Sources $>46$ min round-trip

5

10

H. Utilities (Gas and Electric)

1. Placement

All underground utilities

One underground, one aboveground

$3 \bar{x}$

All aboveground

5

I. Totals for Subdivision

(Tally up all check-point totals.)

49 pts. (low)

1. Low hazard: < 49 points

2. Moderate hazard: $49-68$ points

3. High hazard: $69-83$ points

4. Extreme hazard: $84+$ points 


\section{New Waste Management Facility}

Element

Points

A. Subdivision Design

1. Ingress and egress

Two or more, primary roads

One road, primary route

One way in/out

1

$3 \underline{x}$

5

2. Primary road width

Minimum of $20 \mathrm{ft}(6.1 \mathrm{~m})$

Less than $20 \mathrm{ft}(6.1 \mathrm{~m})$

$1 \underline{X}$

3

3. Road accessibility

Smooth road, grade $<5 \%$

Rough road, grade $>5 \%$

Other

$1 \underline{x}$

3

5

4. Secondary road terminus

Loop roads, cul-de-sacs

Outside radius $>50 \mathrm{ft}(15.2 \mathrm{~m})$

Outside radius $<50 \mathrm{ft}(15.2 \mathrm{~m})$

$1 \underline{x}$

3

Cul-de-sac turnaround

Dead-end roads < $200 \mathrm{ft}(61 \mathrm{~m})$

$3 \underline{x}$

Dead-end roads $>200 \mathrm{ft}(61 \mathrm{~m})$

5

5. Average lot size

More than 10 acres (4.1 ha)

Between 1 and 10 acres (0.4-4.1 ha)

Less than 1 acre (0.4 ha)

1

$3 \underline{x}$

5

6. Street signs

Present [4 in. $(10.2 \mathrm{~cm})$ in size and reflectorized]

Not present

1

$5 \underline{X}$ (3 pts. for Plastic)

B. Vegetation (Fuel Models)

1. NFDRS fuel models

Light (grasses, forbs, sawgrasses, and tundra)

Fuel models A, C, L, N, S, and T

Medium (light brush and small trees)

Fuel models D, E, F, H, P, Q, and U

Heavy (dense brush, timber, and hardwoods)

Fuel models B, G, and O

Slash (timber harvesting residue)

Fuel models J, K, and L

1

$5 \underline{x}$

10

10

2. Defensible space

More than $100 \mathrm{ft}(30.48 \mathrm{~m})$ of treatment from buildings

$30-70 \mathrm{ft}$ (9.1-21.3 $\mathrm{m})$ of treatment from buildings

No defensible space treatment

$1 \underline{x}$
$5-$
10

C. Topography

1. Slope

Less than $9 \%$

$1 \underline{x}$ 
Between 10 and $20 \%$

Between 21 and $30 \%$

Between 31 and $40 \%$

Greater than $41 \%$

D. Additional Rating Factors

1. Rough topography that contains steep canyons

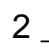

2. Areas with a history of higher fire occurrence than surrounding areas due to special situations such as heavy lightning, railroads, escaped debris burning, arson, etc.

3

3. Areas that are periodically exposed to unusually severe fire weather and strong dry winds

4

E. Roofing Material

1. Construction material

Class A roof

$1 \underline{x}$

Class B roof

3

Class $C$ roof

Non-rated

5

F. Existing Building Construction

1. Materials (predominate)

Noncombustible siding/deck

Noncombustible siding/wood deck

Combustible siding and deck

$1 \underline{x}$

5

10

G. Available Fire Protection

1. Water source availability (on site)

500 gpm (1892.7 Lpm) hydrants < $1000 \mathrm{ft}(304.8 \mathrm{~m})$ apart Hydrants above or draft site

No hydrants or draft site available

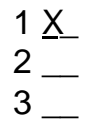

2. Water source availability (off site)

Sources within 20 min round-trip

Sources within 21-45 min round-trip

Sources $>46$ min round-trip

$1 \underline{x}$

5

10

H. Utilities (Gas and Electric)

1. Placement

All underground utilities

One underground, one aboveground

All aboveground

$1 \underline{x}$

3

I. Totals for Subdivision

(Tally up all check-point totals.)

29 pts. (low)

1. Low hazard: < 49 points

2. Moderate hazard: $49-68$ points

3. High hazard: $69-83$ points

4. Extreme hazard: $84+$ points 


\section{AGS/LINAC Buildings}

Element

A. Subdivision Design

1. Ingress and egress

Two or more, primary roads

One road, primary route

One way in/out

2. Primary road width

Minimum of $20 \mathrm{ft}(6.1 \mathrm{~m})$

Less than $20 \mathrm{ft}(6.1 \mathrm{~m})$

3. Road accessibility

Smooth road, grade $<5 \%$

Rough road, grade $>5 \%$

Other

4. Secondary road terminus

Loop roads, cul-de-sacs

Outside radius $>50 \mathrm{ft}(15.2 \mathrm{~m})$

Outside radius $<50 \mathrm{ft}(15.2 \mathrm{~m})$

Cul-de-sac turnaround

Dead-end roads $<200 \mathrm{ft}(61 \mathrm{~m})$

Dead-end roads $>200 \mathrm{ft}(61 \mathrm{~m})$

5. Average lot size

More than 10 acres (4.1 ha)

Between 1 and 10 acres (0.4-4.1 ha)

Less than 1 acre (0.4 ha)

6. Street signs

Present [4 in. $(10.2 \mathrm{~cm})$ in size and reflectorized]

Not present

B. Vegetation (Fuel Models)

1. NFDRS fuel models

Light (grasses, forbs, sawgrasses, and tundra)

Fuel models A, C, L, N, S, and T

Medium (light brush and small trees)

Fuel models D, E, F, H, P, Q, and U

Heavy (dense brush, timber, and hardwoods)

Fuel models B, G, and O

Slash (timber harvesting residue)

Fuel models $\mathrm{J}, \mathrm{K}$, and $\mathrm{L}$

2. Defensible space

More than $100 \mathrm{ft}(30.48 \mathrm{~m})$ of treatment from buildings $30-70 \mathrm{ft}(9.1-21.3 \mathrm{~m})$ of treatment from buildings

No defensible space treatment
Points

1

$3 \underline{x}$

5

$1 \underline{x}$

3

$1 \underline{x}$

3

5

$1 \underline{x}$

3

$3 \underline{x}$

5

1

3

$5 \underline{\bar{x}}$

1

$5 \underline{\bar{X}}$ (3 pts. for plastics)

1

$5 \underline{x}$

10

10

1

$5 \underline{x}$

10

C. Topography

1. Slope 
Less than $9 \%$

Between 10 and $20 \%$

Between 21 and $30 \%$

Between 31 and $40 \%$

Greater than $41 \%$

D. Additional Rating Factors

1. Rough topography that contains steep canyons

2. Areas with a history of higher fire occurrence than surrounding areas due to special situations such as heavy lightning, railroads, escaped debris burning, arson, etc.

3. Areas that are periodically exposed to unusually severe fire weather and strong dry winds

E. Roofing Material

1. Construction material

Class A roof

Class B roof

Class $C$ roof

Non-rated

F. Existing Building Construction

1. Materials (predominate)

Noncombustible siding/deck

Noncombustible siding/wood deck

Combustible siding and deck

\section{G. Available Fire Protection}

1. Water source availability (on site)

500 gpm (1892.7 Lpm) hydrants < $1000 \mathrm{ft}(304.8 \mathrm{~m})$ apart Hydrants above or draft site No hydrants or draft site available

2. Water source availability (off site) Sources within 20 min round-trip Sources within 21-45 min round-trip Sources $>46$ min round-trip

H. Utilities (Gas and Electric)

1. Placement

All underground utilities

One underground, one aboveground

All aboveground

I. Totals for Subdivision

(Tally up all check-point totals.)

1. Low hazard: < 49 points

2. Moderate hazard: $49-68$ points

3. High hazard: $69-83$ points

4. Extreme hazard: $84+$ points
$1 \underline{X}$

4

7

8

10

2

3

4

$1 \underline{x}$

3

5

10

$1 \underline{x}$

5

10

$1 \underline{X}$

2

3

$1 \underline{x}$

5

10

1

$3 \bar{x}$

5

35 pts. (low ) 


\section{Apartment/Cottage Area}

Element

A. Subdivision Design

1. Ingress and egress

Two or more, primary roads

One road, primary route

One way in/out

2. Primary road width

Minimum of $20 \mathrm{ft}(6.1 \mathrm{~m})$

Less than $20 \mathrm{ft}(6.1 \mathrm{~m})$

3. Road accessibility

Smooth road, grade $<5 \%$

Rough road, grade $>5 \%$

Other

4. Secondary road terminus

Loop roads, cul-de-sacs

Outside radius $>50 \mathrm{ft}(15.2 \mathrm{~m})$

Outside radius $<50 \mathrm{ft}(15.2 \mathrm{~m})$

Cul-de-sac turnaround

Dead-end roads $<200 \mathrm{ft}(61 \mathrm{~m})$

Dead-end roads $>200 \mathrm{ft}(61 \mathrm{~m})$

\section{Average lot size}

More than 10 acres (4.1 ha)

Between 1 and 10 acres (0.4-4.1 ha)

Less than 1 acre (0.4 ha)

6. Street signs

Present [4 in. $(10.2 \mathrm{~cm})$ in size and reflectorized]

Not present

B. Vegetation (Fuel Models)

1. NFDRS fuel models

Light (grasses, forbs, sawgrasses, and tundra)

Fuel models A, C, L, N, S, and T

Medium (light brush and small trees)

Fuel models D, E, F, H, P, Q, and U

Heavy (dense brush, timber, and hardwoods)

Fuel models B, G, and O

Slash (timber harvesting residue)

Fuel models $\mathrm{J}, \mathrm{K}$, and $\mathrm{L}$

2. Defensible space

More than $100 \mathrm{ft}(30.48 \mathrm{~m})$ of treatment from buildings $30-70 \mathrm{ft}$ (9.1-21.3 $\mathrm{m})$ of treatment from buildings

No defensible space treatment
Points

1

3

$5 \underline{\bar{X}}$ (cottages)

$1 \underline{X}$

3

$1 \underline{X}$

3

5

$1 \underline{x}$

3

3

$5 \underline{x}$

1

3

$5 \underline{x}$

1

$5 \underline{\bar{X}}$ (3 pts. for plastic)

1

$5 \underline{x}$

10

10

1

5

$10 \underline{x}$

$1 \underline{X}$

C. Topography

Slope

Less than 9\% 
Between 10 and $20 \%$

Between 21 and $30 \%$

Between 31 and $40 \%$

Greater than $41 \%$

4

7

8

10

D. Additional Rating Factors

1. Rough topography that contains steep canyons

2

2. Areas with a history of higher fire occurrence than surrounding areas due to special situations such as heavy lightning, railroads, escaped debris burning, arson, etc.

3. Areas that are periodically exposed to unusually severe fire weather and strong dry winds

4

E. Roofing Material

1. Construction material

Class A roof

Class B roof

Class $C$ roof

Non-rated

$1 \underline{X}$

3

5

10

F. Existing Building Construction

1. Materials (predominate)

Noncombustible siding/deck

Noncombustible siding/wood deck

Combustible siding and deck

1

5

$10 \underline{x}$

G. Available Fire Protection

1. Water source availability (on site)

$500 \mathrm{gpm}(1892.7 \mathrm{Lpm})$ hydrants < $1000 \mathrm{ft}(304.8 \mathrm{~m})$ apart Hydrants above or draft site

No hydrants or draft site available

$1 \underline{x}$

2

3

2. Water source availability (off site)

Sources within 20 min round-trip

Sources within 21-45 min round-trip

Sources $>46$ min round-trip

$1 \underline{X}$

5

10

H. Utilities (Gas and Electric)

1. Placement

All underground utilities

One underground, one aboveground

All aboveground

$1 \underline{X}$

3

I. Totals for Subdivision

(Tally up all check-point totals.)

51 pts. (moderate)

1. Low hazard: < 49 points

2. Moderate hazard: $49-68$ points

3. High hazard: $69-83$ points

4. Extreme hazard: $84+$ points 


\section{General Perimeter of BNL Central Core Buildings}

Note: These facilities are included for comparison. They are technically outside the interface region.

Element

A. Subdivision Design

1. Ingress and egress

Two or more, primary roads

One road, primary route

One way in/out

2. Primary road width

Minimum of $20 \mathrm{ft}(6.1 \mathrm{~m})$

Less than $20 \mathrm{ft}(6.1 \mathrm{~m})$

3. Road accessibility

Smooth road, grade $<5 \%$

Rough road, grade $>5 \%$

Other

4. Secondary road terminus

Loop roads, cul-de-sacs

Outside radius $>50 \mathrm{ft}(15.2 \mathrm{~m})$

Outside radius $<50 \mathrm{ft}(15.2 \mathrm{~m})$

Cul-de-sac turnaround

Dead-end roads $<200 \mathrm{ft}(61 \mathrm{~m})$

Dead-end roads $>200 \mathrm{ft}(61 \mathrm{~m})$

5. Average lot size

More than 10 acres (4.1 ha)

Between 1 and 10 acres (0.4-4.1 ha)

Less than 1 acre (0.4 ha)

6. Street signs

Present [4 in. $(10.2 \mathrm{~cm})$ in size and reflectorized]

Not present

B. Vegetation (Fuel Models)

1. NFDRS fuel models

Light (grasses, forbs, sawgrasses, and tundra)

Fuel models A, C, L, N, S, and T

Medium (light brush and small trees)

Fuel models D, E, F, H, P, Q, and U

Heavy (dense brush, timber, and hardwoods)

Fuel models B, G, and O

Slash (timber harvesting residue)

Fuel models $\mathrm{J}, \mathrm{K}$, and $\mathrm{L}$

2. Defensible space

More than $100 \mathrm{ft}(30.48 \mathrm{~m})$ of treatment from buildings

$30-70 \mathrm{ft}$ (9.1-21.3 $\mathrm{m})$ of treatment from buildings

No defensible space treatment

C. Topography

1. Slope

Less than $9 \%$
Points

$1 \underline{X}$

3

5

$1 \underline{X}$

3

$1 \underline{x}$

3

5

$1 \underline{X}$

3

$3 \underline{X}$

5

1

3

$5 \underline{x}$

1

$5 \underline{\bar{X}}$ (3 pts. for plastic)

$1 \underline{x}$

5

10

10

$1 \underline{X}$

5

10

$1 \underline{X}$ 
Between 10 and $20 \%$

Between 21 and $30 \%$

Between 31 and $40 \%$

Greater than $41 \%$

D. Additional Rating Factors

1. Rough topography that contains steep canyons

2. Areas with a history of higher fire occurrence than surrounding areas due to special situations such as heavy lightning, railroads, escaped debris burning, arson, etc.

3

3. Areas that are periodically exposed to unusually severe fire weather and strong dry winds

4

E. Roofing Material

1. Construction material

Class A roof

Class B roof

$1 \underline{x}$

Class $C$ roof

Non-rated

5

10

F. Existing Building Construction

1. Materials (predominate)

Noncombustible siding/deck

Noncombustible siding/wood deck

Combustible siding and deck

$1 \underline{x}$

5

10

G. Available Fire Protection

1. Water source availability (on site)

500 gpm (1892.7 Lpm) hydrants < $1000 \mathrm{ft}(304.8 \mathrm{~m})$ apart Hydrants above or draft site

No hydrants or draft site available

$1 \underline{x}$

2

3

2. Water source availability (off site)

Sources within 20 min round-trip

Sources within 21-45 min round-trip

Sources $>46$ min round-trip

$1 \underline{x}$

5

10

H. Utilities (Gas and Electric)

1. Placement

All underground utilities

One underground, one aboveground

All aboveground

$1 \underline{x}$

3

5

I. Totals for Subdivision

(Tally up all check-point totals.)

23 pts. (low)

1. Low hazard: < 49 points

2. Moderate hazard: $49-68$ points

3. High hazard: $69-83$ points

4. Extreme hazard: $84+$ points 


\section{Miscellaneous Small Monitoring and Well Houses}

Element

Points

A. Subdivision Design

1. Ingress and egress

Two or more, primary roads

One road, primary route

One way in/out

1

3

$5 \underline{\bar{X}}$

2. Primary road width

Minimum of $20 \mathrm{ft}(6.1 \mathrm{~m})$

Less than $20 \mathrm{ft}(6.1 \mathrm{~m})$

1

$3 \underline{\bar{x}}$

3. Road accessibility

Smooth road, grade $<5 \%$

1

Rough road, grade $>5 \%$

$3 \underline{x}$

Other

5

4. Secondary road terminus

Loop roads, cul-de-sacs

Outside radius $>50 \mathrm{ft}(15.2 \mathrm{~m})$

1

Outside radius $<50 \mathrm{ft}(15.2 \mathrm{~m})$

$3 \underline{x}$

Cul-de-sac turnaround

Dead-end roads $<200 \mathrm{ft}(61 \mathrm{~m})$

Dead-end roads $>200 \mathrm{ft}(61 \mathrm{~m})$

3

$5 \underline{\bar{x}}$

5. Average lot size

More than 10 acres (4.1 ha)

Between 1 and 10 acres (0.4-4.1 ha)

Less than 1 acre (0.4 ha)

$1 \underline{x}$

3

5

6. Street signs

Present [4 in. $(10.2 \mathrm{~cm})$ in size and reflectorized]

Not present

1

B. Vegetation (Fuel Models)

1. NFDRS fuel models

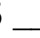

Light (grasses, forbs, sawgrasses, and tundra)

Fuel models A, C, L, N, S, and T

Medium (light brush and small trees)

Fuel models D, E, F, H, P, Q, and U

Heavy (dense brush, timber, and hardwoods)

Fuel models B, G, and O

Slash (timber harvesting residue)

Fuel models $\mathrm{J}, \mathrm{K}$, and $\mathrm{L}$

1

$5 \underline{x}$

10

10

2. Defensible space

More than $100 \mathrm{ft}(30.48 \mathrm{~m})$ of treatment from buildings $30-70 \mathrm{ft}(9.1-21.3 \mathrm{~m})$ of treatment from buildings

No defensible space treatment
1

5

$10 \underline{x}$

C. Topography

1. Slope 
Less than $9 \%$

Between 10 and $20 \%$

Between 21 and $30 \%$

Between 31 and $40 \%$

Greater than $41 \%$

D. Additional Rating Factors

1. Rough topography that contains steep canyons

2. Areas with a history of higher fire occurrence than surrounding areas due to special situations such as heavy lightning, railroads, escaped debris burning, arson, etc.

3. Areas that are periodically exposed to unusually severe fire weather and strong dry winds

E. Roofing Material

1. Construction material

Class A roof

Class B roof

Class $C$ roof

Non-rated

F. Existing Building Construction

1. Materials (predominate)

Noncombustible siding/deck

Noncombustible siding/wood deck

Combustible siding and deck

\section{G. Available Fire Protection}

1. Water source availability (on site)

500 gpm (1892.7 Lpm) hydrants < $1000 \mathrm{ft}(304.8 \mathrm{~m})$ apart Hydrants above or draft site No hydrants or draft site available

2. Water source availability (off site) Sources within 20 min round-trip Sources within 21-45 min round-trip Sources $>46$ min round-trip

H. Utilities (Gas and Electric)

1. Placement

All underground utilities

One underground, one aboveground

All aboveground

I. Totals for Subdivision

(Tally up all check-point totals.)

1. Low hazard: < 49 points

2. Moderate hazard: $49-68$ points

3. High hazard: $69-83$ points

4. Extreme hazard: 84+ points

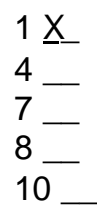

2

3

4

$1 \underline{x}$

3

10

$1 \underline{x}$

5

10
1

$3 \frac{2}{x}$

$1 \underline{x}$

5

10

1

3

$5 \underline{x}$

52 pts. (moderate) 


\section{Appendix C}

\section{Radiological Uptake by Soils}

The following is an outtake from the Environmental Restoration Division WebPages on Operational Unit 1 , radiologically contaminated soils.

\section{History and Description of Contaminated Locations}

Soils at a number of locations on the BNL site (see maps below) contain contaminants that will require cleanup.

Radiologically contaminated soils

- Former Hazardous Waste Management Facility (HWMF) - The largest volume of contaminated soil is located at the HWMF. It was used from 1947 to 1997 as a central receiving, processing and storage facility for radioactive and hazardous waste generated at BNL. The primary soil contaminants at the HWMF are cesium-137 and strontium-90. Mercury is also present.

- Waste Concentration Facility- Cesium-137 and strontium-90 contamination was found in soils here. This facility has been used since 1949 for reducing the volume of liquid radioactive waste prior to disposal. It is still an operational facility. Three large storage tanks were in use here from 1949 to 1987, and were removed in 1994. Additional tanks and piping still remain.

- Reclamation Facility and Sump Outfall Area - Radioactive elements were found in soils at the reclamation facility and in a sump outfall east of the facility. This facility was used from the late 1950 s through the late 1960 s to clean radioactive contaminants from clothing and equipment. It is no longer used for decontamination, although it is still in use for routine laundry. Water from decontamination of equipment was discharged at the sump outfall area until late 1969.

- Other Sitewide Soils - Low levels of cesium-137 were found in soils near several buildings in the center of the BNL site. Soils from the HWMF were used as landscaping and fill material at these locations.

Two other areas at BNL were examined for radiological contamination. The Alternating Gradient Synchrotron (AGS) storage yards hold steel and equipment that is being stored for potential reuse at the AGS. The Low Mass Criticality Facility was used for research from the mid-1950s to the mid-1960s, and for temporary drum storage from June 1983 to March 1984.

No contamination at levels of human health concern was found at these two locations. No cleanup of these areas is required. Institutional controls and monitoring will continue.

\section{Cleanup Goals for Radiologically Contaminated Soils}

\section{Investigation Findings}

Several locations, or areas of concern (AOCs), are examined in this remedial investigation. No areas had chemical contamination above acceptable risk levels as defined under CERCLA.

Waste Concentration Facility (AOC 10)

BNL's waste concentration facility was used to temporarily store and process liquid radioactive waste. Soil sampling detected the radioactive element cesium-137. Levels of cesium-137 were greater than the cleanup goal established for residential areas. This goal is $23 \mathrm{pCi} / \mathrm{g}$ at a time 50 years in the future. (PicoCuries per gram is a measure of radioactivity per unit weight of soil.) Access to this area is currently restricted. 
Cleanup has already taken place. Three 100,000-gallon aboveground storage tanks were removed in 1994 and 1995. Six underground storage tanks will also be removed. Further cleanup action may be required in this area.

\section{Lawns and Landscaping Soils (AOC 16)}

In 1980 and 1983, aerial radiation surveys identified twenty-three areas for further investigation. Radioactive contaminants, primarily cesium-137, were found above cleanup goals for residential areas in several locations. Some of these locations may require further cleanup action.

Deer graze on BNL lawns, including those containing cesium-137. Low levels of cesium137 have been detected in deer sampled on the BNL site. The potential health risk to humans who consume deer is very low. Additionally, hunting on the BNL site is prohibited. Tritium was detected in subsurface soils at a facility that produces medical isotopes (the Brookhaven LINAC Isotope Producer, or BLIP). Routine monitoring has also found tritium in groundwater near the BLIP. This facility may require further cleanup action. A report on the BLIP will be released later this year. The BLIP Engineering Evaluation/Cost Analysis will give more details about the contamination that has been found at the BLIP and examine the cleanup alternatives.

Because the lawns and landscaping soils are located in developed areas of the BNL site, no ecologically sensitive areas are affected.

\section{Former Low Mass Criticality Facility (AOC 17)}

Historical photographs show that, after decommisioning, this facility was used for storage of chemical drums. A ground-based survey found no radioactive contaminants at levels greater than residential cleanup goals.

\section{AGS Storage Yards (AOC 18)}

These three storage yards (see map) hold steel from the Alternating Gradient Synchrotron. It was suggested that radioactive particles of steel might have contaminated the soil. Sampling found no radioactive contaminants at levels greater than residential cleanup goals. 


\section{Appendix D}

\section{Reference Pictures}

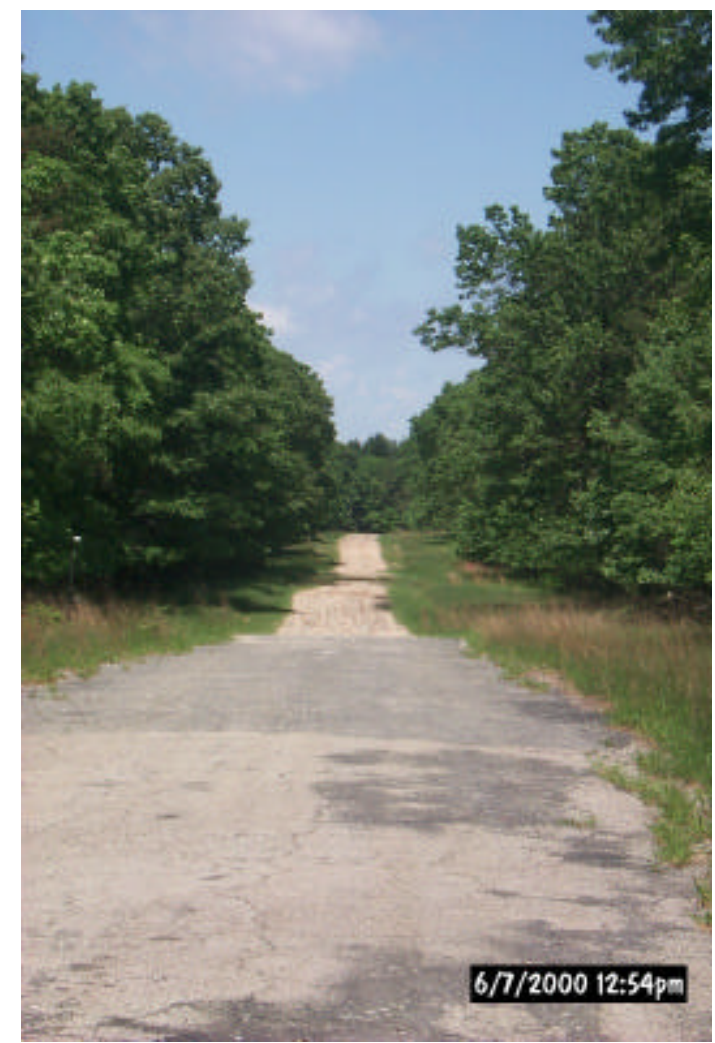

Picture 1 Paved access road, which turns which turns into a dirt road as it enters the remote portions of site.

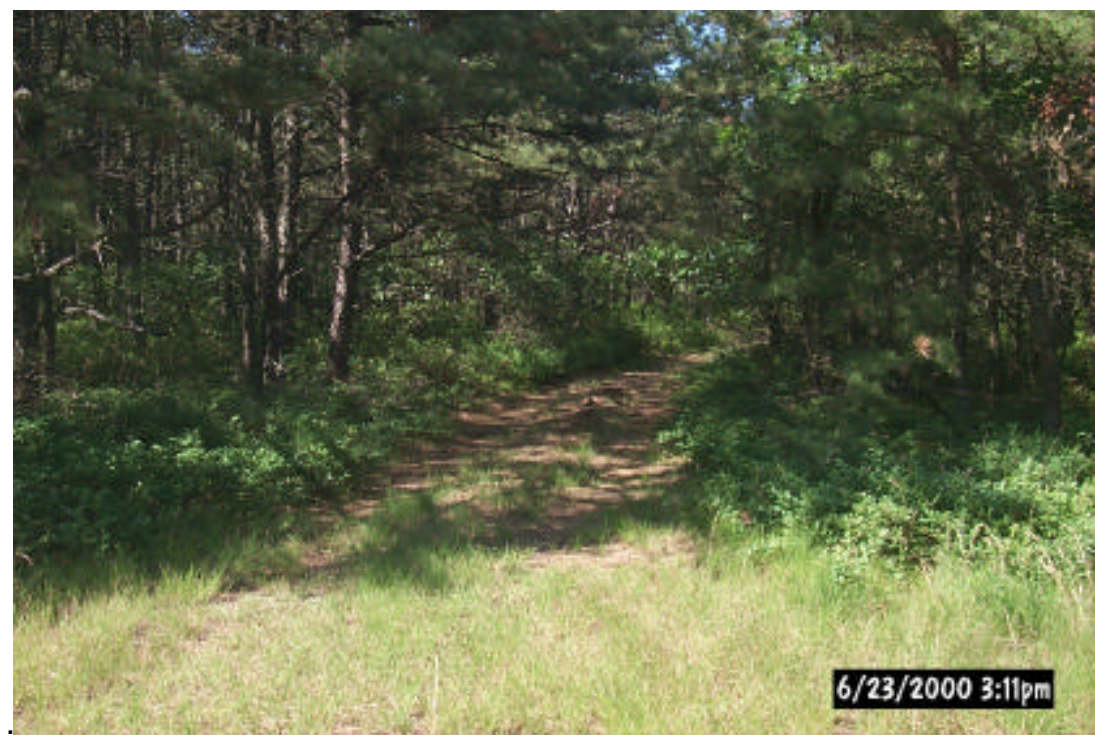

Picture 2 An active access road which is becoming heavily over grown. 
BNL WILDLAND FIRE ASSESSEMENT AP

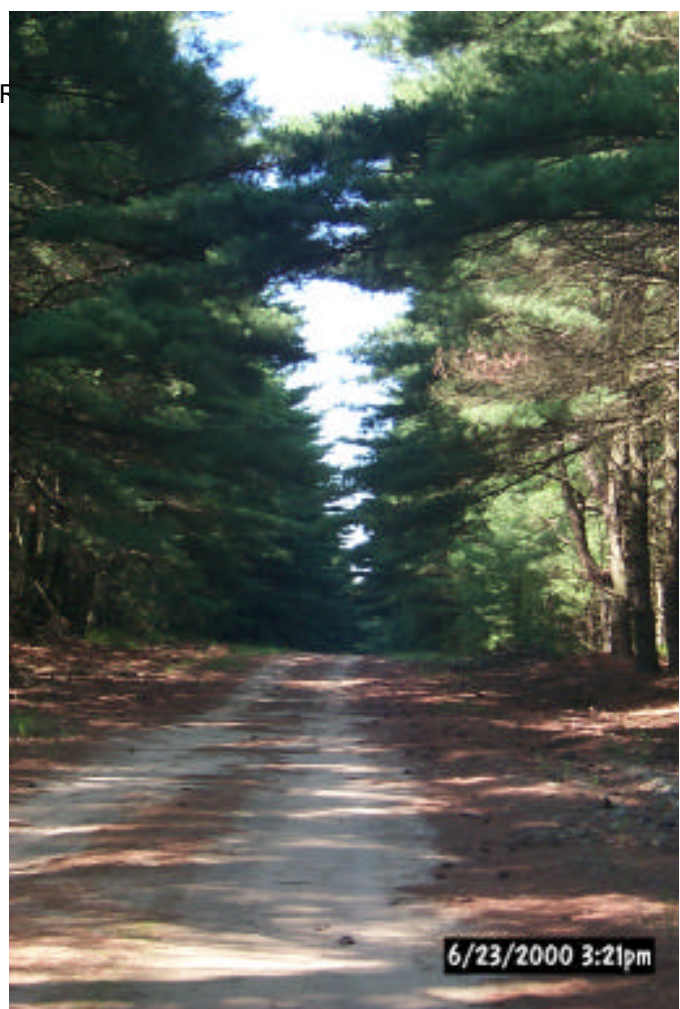

Picture 3 The forest canopy is overgrowing the firebreak and will allow a moderate fire to jump across the boundary. Also, combustible litter crosses the roadway, which will allow a small fire to jump with easy.

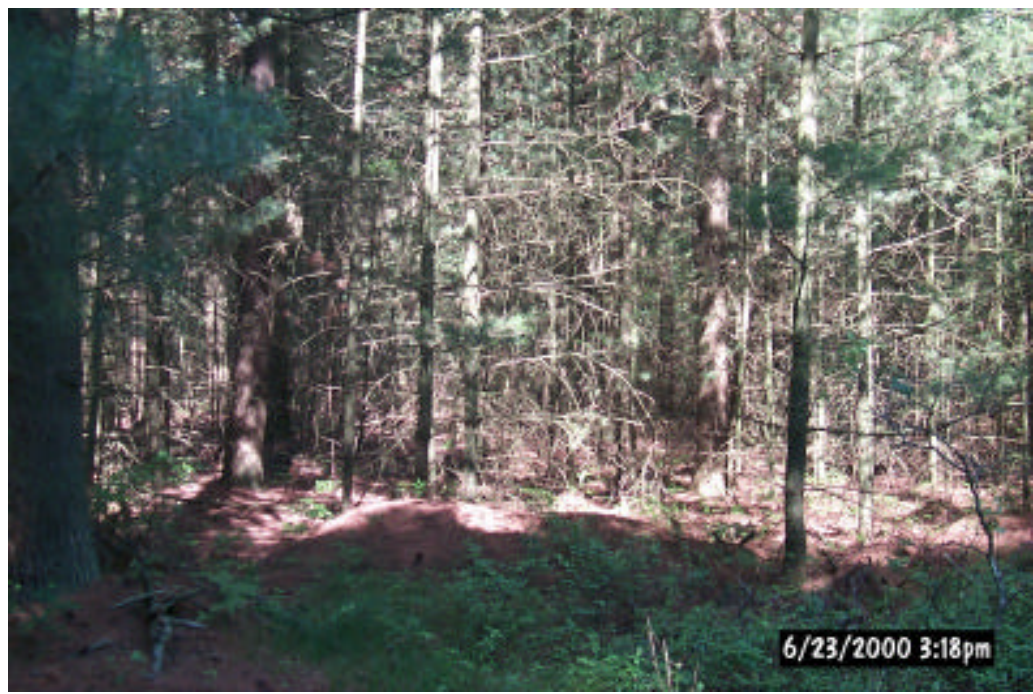

Picture 4 Fire normally starts on the floor of the forest. The flames from the combustible covering can easily climb the small branches ("the fuel ladder") from the floor to the tree canopy. Once in the canopy, fire burns intensely. 


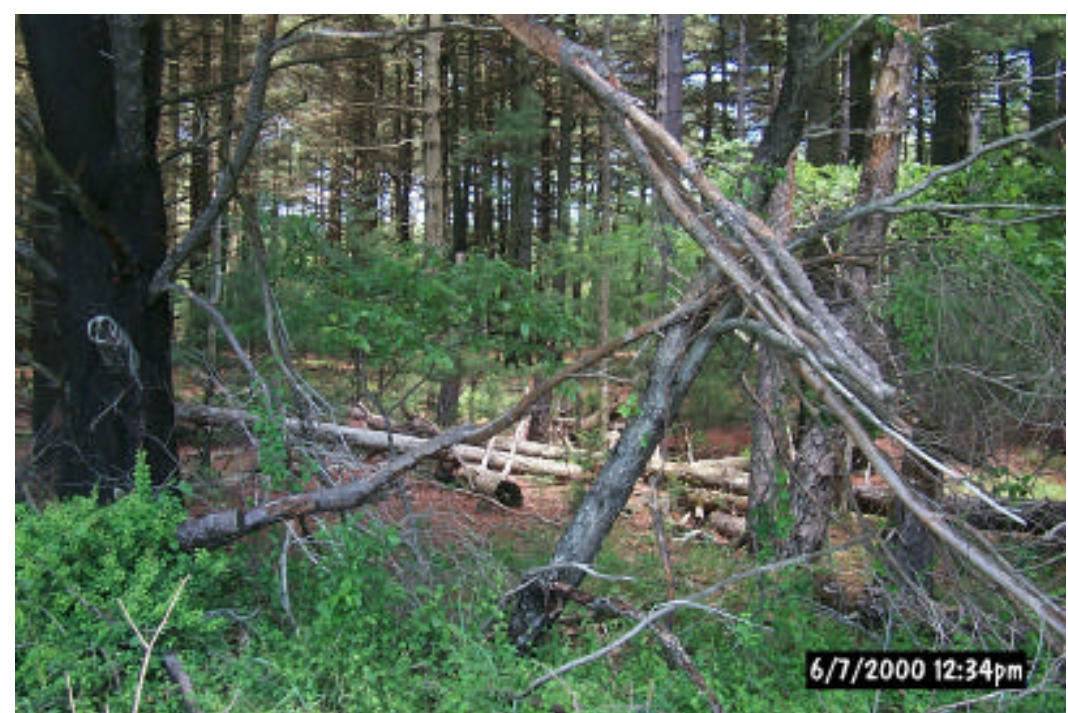

Picture 9 Example of "dead and down" trees that significantly adds to fuel loading at the floor level.

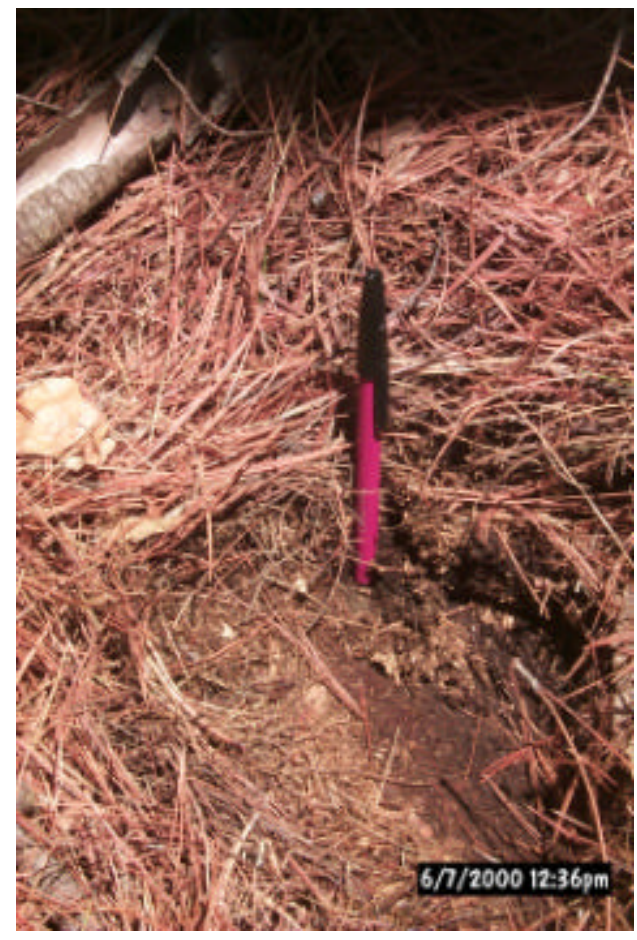

Picture 10 The depth of combustible pine needles is demonstrated by a pen stuck in the ground. The decaying litter creates a peat that is several inches thick. The peat will support combustion underground for several days, increasing the risk of re-ignition. 


\section{Appendix G: Wildland Interface Survey}

Note: If this final section is missing from your document, you may go to

http://www.bnl.gov/emergencyservices/FP/Wildland-

fire/files/pdf/2002\%20Wildland\%20Inerface\%20Survey\%20Final.pdf and download the PDF file. 


\section{Brookhaven}

National Laboratory
BNL Fire Protection Engineering Phone 6313444259

\section{Wildland Fire Interface Survey}

\section{Managing the Woods Today to Manage the Fire Tomorrow}

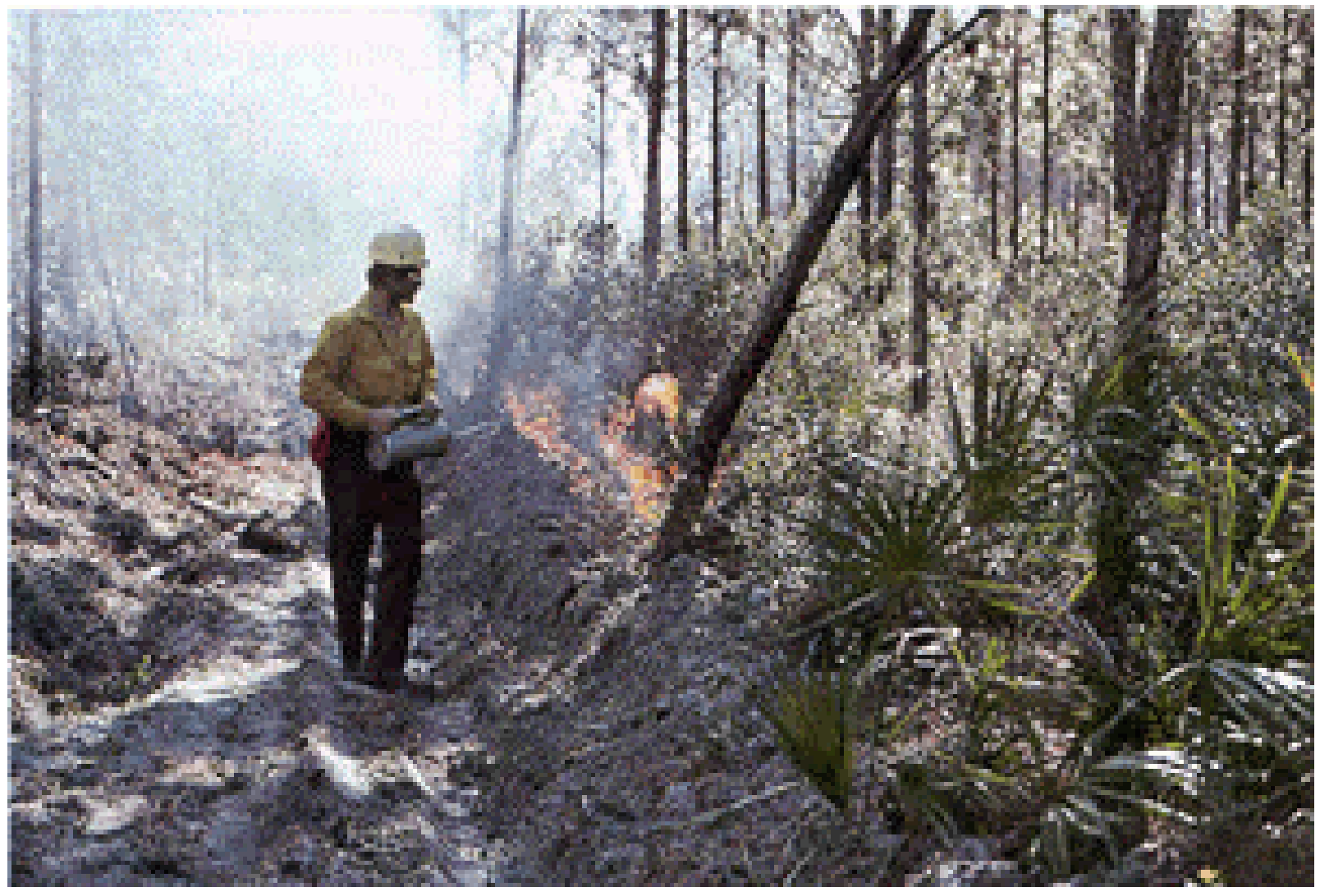

Prepared by: 


\section{Wildland Fire Interface Survey}

\section{Managing the Woods Today to Mange the Fire Tomorrow}

\section{Introduction}

2000 was the "year of the fire" for Department of Energy (DOE) facilities. Lawrence Livermore National Laboratory was shut down for 10 days and DOE's Hanford site was shut down for three days as the results of wildland fires. These incidents emphasize the need for Wildland Interface Zones to be defined and the adjoining woods to be managed. BNL has over 3,000 acres of woodland property with many major facilities along the wildland interface zone. In addition to impacting the entire site and the experimental programs, a large fire could involve bordering communities and their homes. This analysis documents BNL's structures along the interface zone, defines minimum levels protective measures that are needed to reduce fire damage, and identifies prudent corrective actions needed to prepare for survival.

\section{Methodology}

\section{Determining the Wildland Interface Zone}

To define what facilities were on the Wildland Interface Zone, the term "Wildland Interface" needed to be defined. The 2000 Urban-Wildland Interface Code $^{1}$ provided the following definition for a term used in their code:

Urban-Wildland Interface Area is that geographical area where structures and other human developments meets or intermingles with wildland ${ }^{2}$ or vegetative fuels.

The next step in the project was to develop an initial list of facilities based on office information. BNL site maps included an AutoCAD layer for the tree lines. This was based on aerial photographs and may not have been accurate, but was an initial starting point.

From the list of facilities that adjoined directly to wildland areas, a visit was made to verify the field conditions. A field inspection was used to verify the conditions. The list was then updated.

To evaluate the facilities level of protection against a wildland fire, literature research was conducted. The National Fire Protection Association's National Fire Code Pamphlet 299, "Standard for Protection of Life and Property from Wildland Fires " provided the majority of information regarding risk evaluations. The joint agency for wildland land fire education, www. firewise.org, provided details on facility configuration for protection against wildland fire damage. From these two sources, a checklist was compiled and used during facility inspection.

\footnotetext{
1 "2000 Urban Wildland-Interface Code," International Fire Code Institute, Whittier, California

${ }^{2}$ According to the 2000 Urban- Wildland Interface Code, Wildland is and area in which development is essentially nonexistent, except for roads, railroads, power lines and similar facilities.
} 
The most important elements protecting a structure against damage from a wildland fire are 1) non-combustible construction, and 2) distance from the vegetation. Non-combustible roofing is the most significant factor due to its ability to resist ignition from burning brands that shower from the sky over entire blocks of area during wildland fires. Distance from the woods, on the other hand, protects the facilities from radiant heat and its ignition mechanics. The separation distance was formerly called "Defensible Space" due to the implication that the fire department could intercede. The term more recently used is "Survivable Space," which eliminates the dependence on manual suppression and implies that the distance alone provides the protection.

This report presents the BNL list of facilities, their status with respect to the protective measures, and highlights needed improvements. 


\section{Wildland Interface Survey}

\section{Sample Wildland Fire Interface Survey Building Checklist (Based on NFPA 299 \& www.firewise.org)}

Insert Building Number

A)Means of Ingress and Egress

1) $\mathrm{X}$ sufficient

2)_insufficient ${ }^{* *}$

a)___two or more roads

b) $\underline{X}$ one way in and out

3)Size of Road

a) $\quad \underline{x}>20 \mathrm{ft}$. wide

B)Signs

b) $<20 \mathrm{ft}$. wide

1)__ not present*

2) $\mathrm{X}$ present

a) if present are they legible (meeting with NFPA codes)

C)Building Construction

1) $\underline{X}$ low (class A roof, noncombustible siding and roof)

2)___ moderate (class $B$ roof, noncombustible siding and roof)

3)_ high (class $\mathrm{C}$ or nonrated roof, combustible siding and deck)

D)Additional Building Construction

1)__ not present

2) $\mathbf{X}$ present (class $A, B, C)$

E)Vegetation and Landscape

1) not maintained ${ }^{* *}$

2)_ $\mathrm{X}$ maintained

F)Survivable Space

a) if so explain.... adequate or not.

1) $\mathbf{X}$ urban intermix

2)__ urban interface

3) Distance from Woodland

a) $>100 \mathrm{ft}$.

b) $30-70 \mathrm{ft}$.

4)Slope

c) $\underline{\mathbf{X}}<30 \mathrm{ft}$.(no survivable space) $)^{\star *}$

a) $\quad x<$ than $9 \%$

b) between $10 \%$ and $20 \%$

c) between $21 \%$ and $30 \%$

d)_ between $31 \%$ and $40 \%$

G)Water Availability

e)__ > than $41 \%$ **

1) $\mathrm{no}^{\text {** }}$

2)_ $\mathbf{X}$ yes(distance ft.)

a) $75 \mathrm{ft}$. (915)

b) $175 \mathrm{ft}$. (916)

c) $275 \mathrm{ft}$. (917)

** must explain why the problem is as such and ways to solve the problem.

\section{Comments:}

-- even though the woodland surrounds three sides of them, they are so small that if they do go and we can't put them out, we shouldn't be firemen.

-- they are easily accessible so can be put out very quickly.

--the roads should be labeled better for more efficient access to them. 


\section{Photographs of Sample Concerns and Issues}

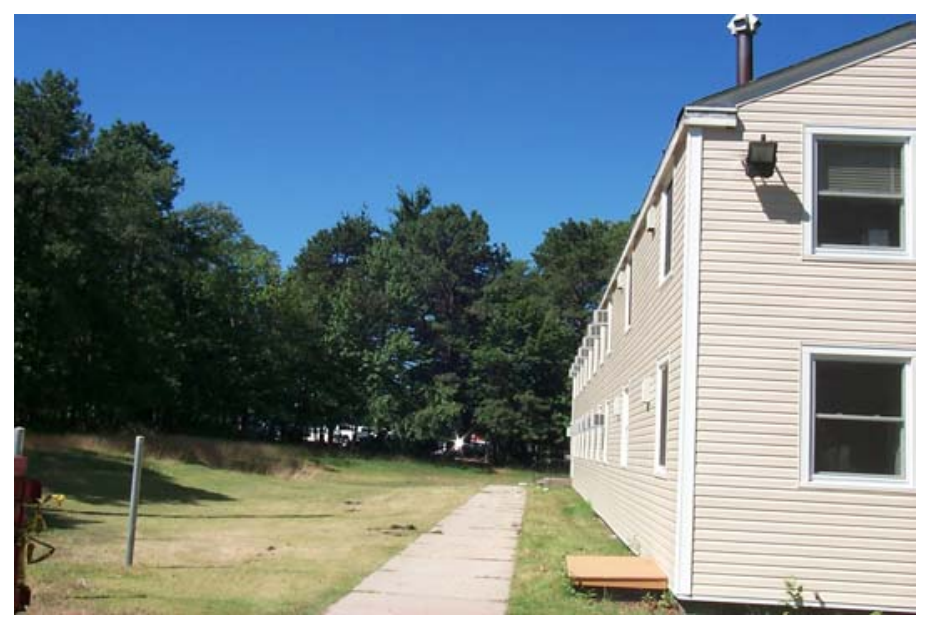

- Figure 1 Preferred clearance to the tree line to allow fire department intervention and control (BIdg 153)

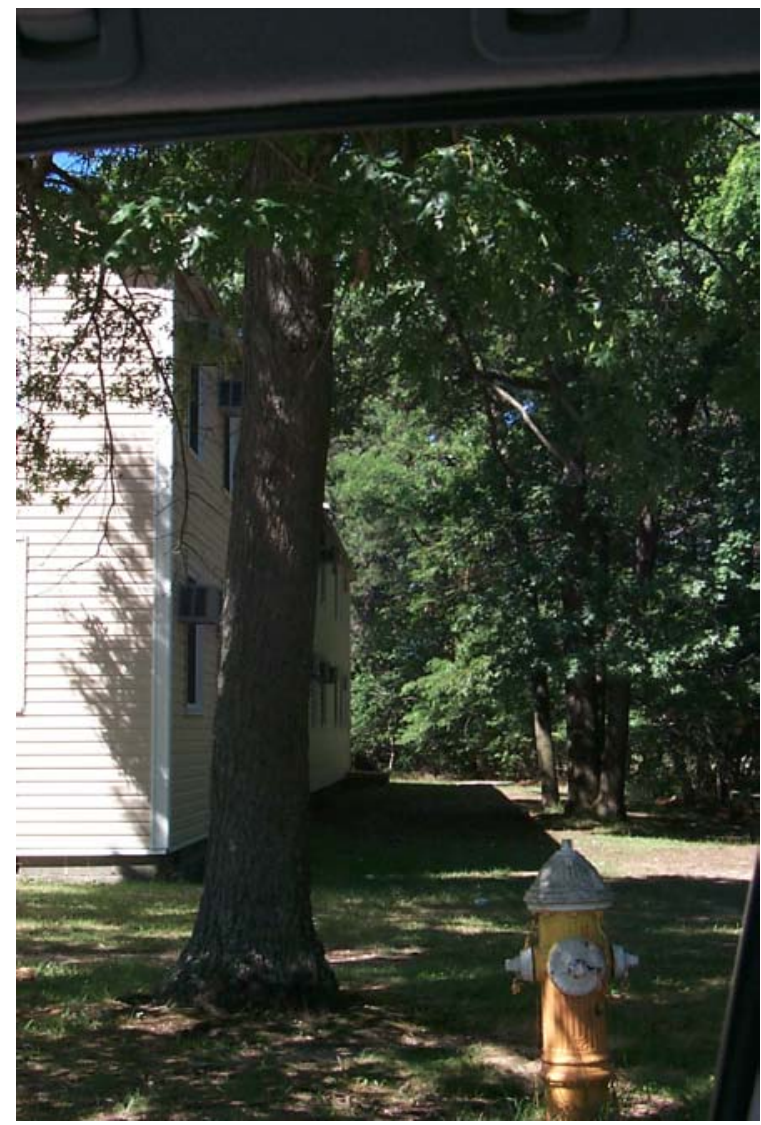

- Figure 2 Another side of Bldg 153 showing insufficient protective clearance and endangering the buidling 


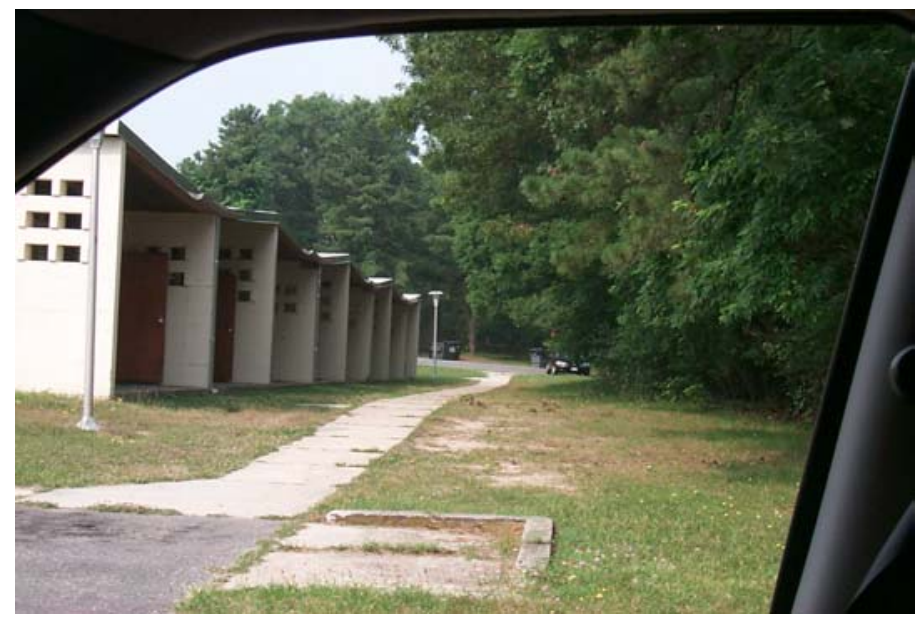

Figure 3 Apartment Area "Efficiency" Apartments with woods and tree canopy encroaching on buildings

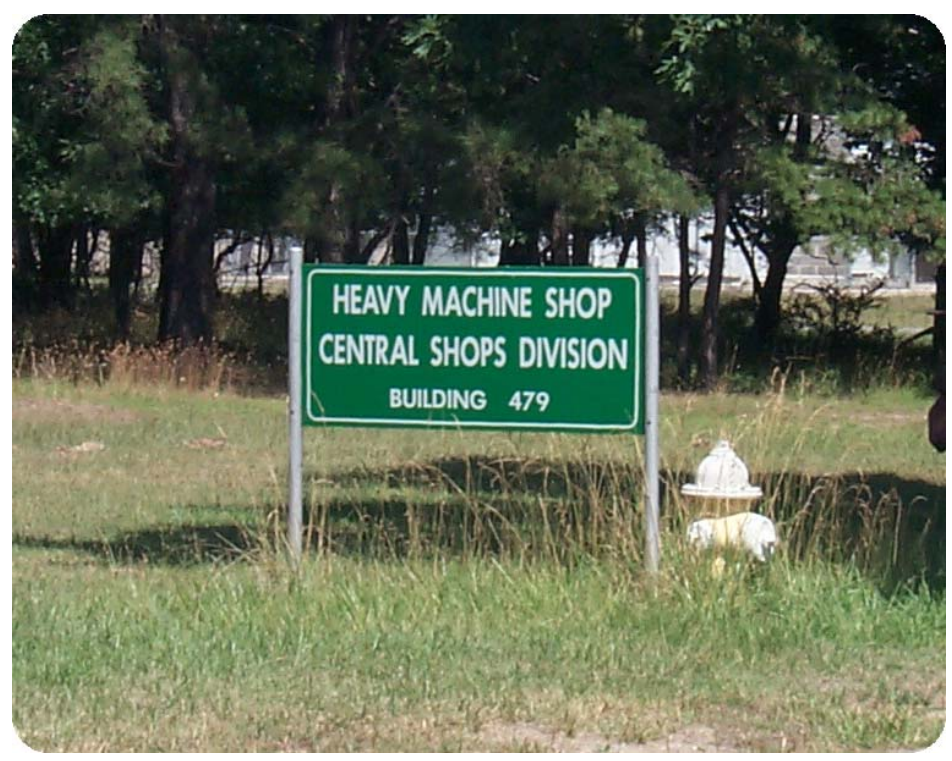

- Figure 4 Sample sign that provides clear direction and identification to fire department response 


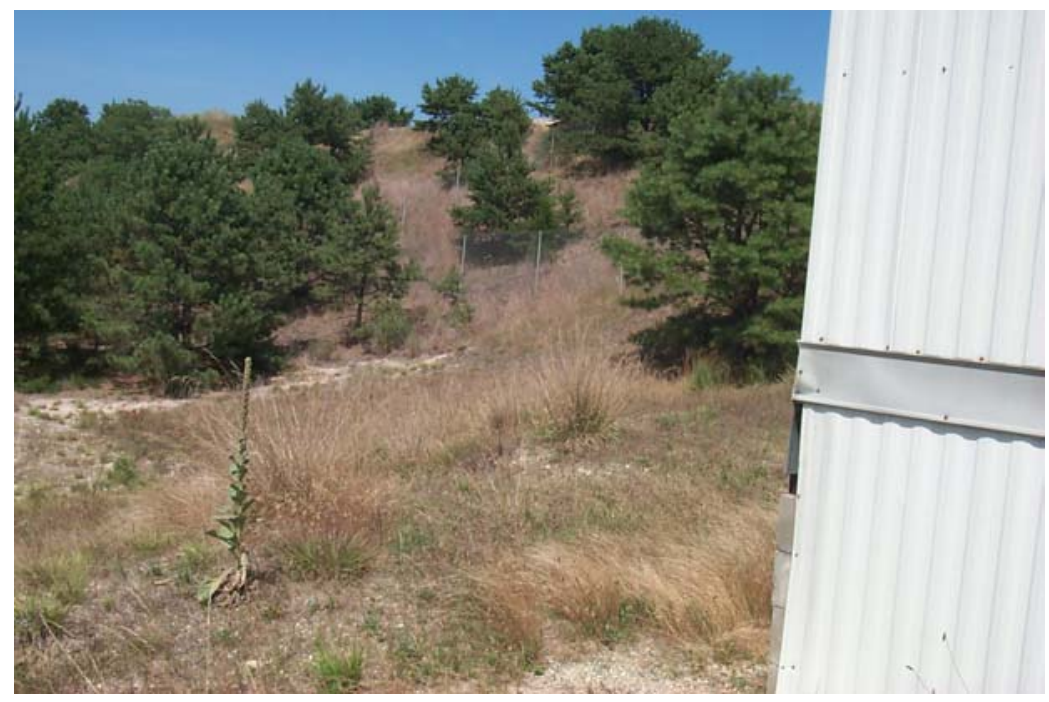

- Figure 5 Up hill ground slope at RHIC that increase the fire hazard to a facilitiesl

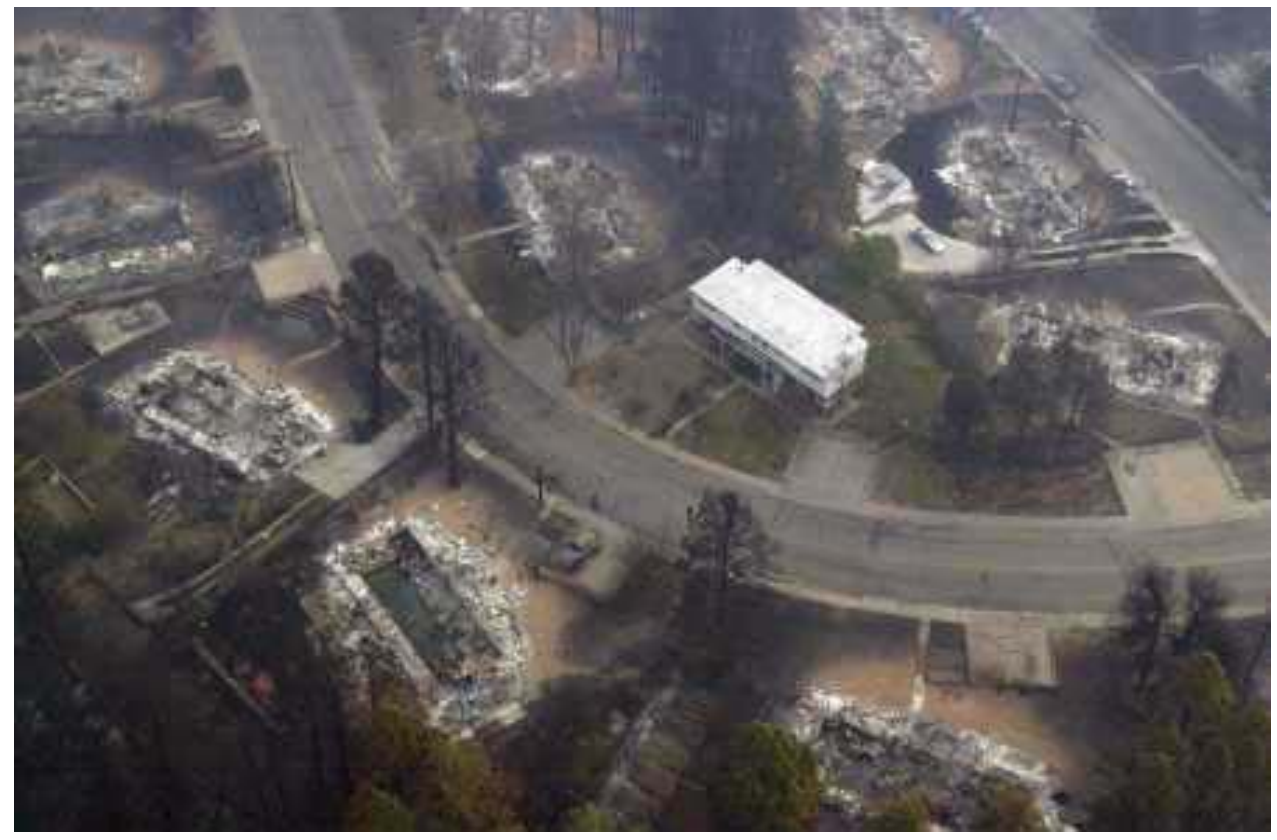

- Figure 6 Spared Building (non-combustible roof and clearance to the tree line) versus less fortunate homes 


\section{Wildland Interface Zone Survey}

\begin{tabular}{|c|c|c|c|c|c|c|c|c|c|c|}
\hline \multirow[b]{2}{*}{$\begin{array}{l}\bar{\Phi} \\
\frac{0}{E} \\
\bar{\Sigma} \\
\bar{z} \\
\frac{\delta}{0} \\
\frac{\overline{0}}{\infty}\end{array}$} & \multirow[b]{2}{*}{$\begin{array}{l}\stackrel{0}{E} \\
\frac{\pi}{z} \\
\frac{\delta}{0} \\
\frac{0}{0}\end{array}$} & \multicolumn{2}{|c|}{ Ingress/Egress } & \multirow[b]{2}{*}{ 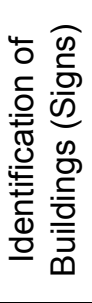 } & \multicolumn{2}{|c|}{ Bldg Fire Resistance } & \multicolumn{3}{|c|}{ Survivable Space } & \multirow[b]{2}{*}{ 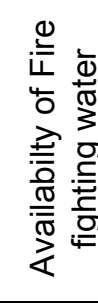 } \\
\hline & & 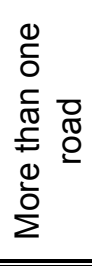 & 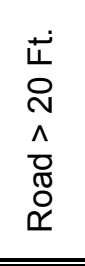 & & 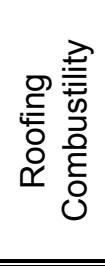 & 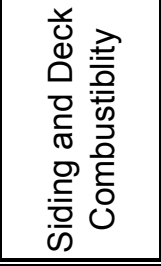 & 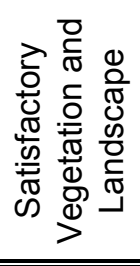 & 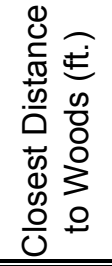 & 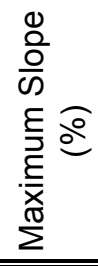 & \\
\hline 30 & $\begin{array}{l}\text { BROOKHAVEN } \\
\text { CENTER }\end{array}$ & Yes & Yes & No & Low & Low & Yes & $30-70$ & $21-30$ & Good \\
\hline 50 & $\begin{array}{l}\text { POLICE } \\
\text { HEADQUARTERS }\end{array}$ & Yes & Yes & No & Low & Low & No & $30-70$ & $<9$ & Good \\
\hline 51 & OER/ATMOSPHERIC & Yes & Yes & No & Low & Low & No & $<30$ & $<9$ & Good \\
\hline 170 & $\begin{array}{l}\text { COMPTON-MENS } \\
\text { RESID } \\
\end{array}$ & No & Yes & No & Low & Low & Yes & $<30$ & $21-30$ & Good \\
\hline 180 & FLEMING-MENS RESID & Yes & Yes & No & Low & Low & No & $30-70$ & $<9$ & Good \\
\hline 244 & $\begin{array}{l}\text { BLDGING } \\
\text { MAINTENANCE SHOP }\end{array}$ & Yes & Yes & No & Low & Low & No & $30-70$ & $<9$ & Good \\
\hline 257 & GUEST HOUSE & Yes & Yes & No & Low & Moderate & No & $<30$ & $<9$ & Good \\
\hline 258 & $\begin{array}{l}\text { CURIE-WOMEN'S } \\
\text { RESIDNCE }\end{array}$ & Yes & Yes & No & Low & Moderate & No & $<30$ & $<9$ & Good \\
\hline 302 & APARTMENT 28 & Yes & Yes & No & Low & Moderate & Yes & $30-70$ & $<9$ & Good \\
\hline 303 & APARTMENT 34 & Yes & Yes & No & Low & Moderate & Yes & $30-70$ & $<9$ & Good \\
\hline 304 & $\begin{array}{l}\text { APARTMENT } \\
\text { STORAGE }\end{array}$ & Yes & Yes & Yes & Low & Moderate & Yes & $30-70$ & $<9$ & Good \\
\hline 306 & APARTMENT 13 & Yes & Yes & Yes & Low & Moderate & Yes & $30-70$ & $<9$ & Good \\
\hline 307 & APARTMENT 11 & Yes & Yes & Yes & Low & Moderate & Yes & $30-70$ & $<9$ & Good \\
\hline 324 & APARTMENT 9 & Yes & Yes & Yes & Low & Moderate & Yes & $30-70$ & $<9$ & Good \\
\hline 325 & APARTMENT 7 & Yes & Yes & Yes & Low & Moderate & Yes & $30-70$ & $<9$ & Good \\
\hline 327 & APARTMENT 24 & Yes & Yes & Yes & Low & Moderate & Yes & $30-70$ & $<9$ & Good \\
\hline 328 & APARTMENT 26 & Yes & Yes & Yes & Low & Moderate & Yes & $30-70$ & $<9$ & Good \\
\hline 330 & APARTMENT 8 & Yes & Yes & Yes & Low & Moderate & Yes & $30-70$ & $<9$ & Good \\
\hline 331 & APARTMENT 10 & Yes & Yes & Yes & Low & Moderate & Yes & $30-70$ & $<9$ & Good \\
\hline 334 & APARTMENT 30 & Yes & Yes & Yes & Low & Moderate & Yes & $30-70$ & $<9$ & Good \\
\hline 335 & APARTMENT 36 & Yes & Yes & Yes & Low & Moderate & Yes & $30-70$ & $<9$ & Good \\
\hline 348 & CALIBRATION & Yes & Yes & Yes & Low & Moderate & No & $<30$ & $<9$ & Good \\
\hline 349 & APARTMENT 2 & Yes & Yes & Yes & Low & Moderate & Yes & $30-70$ & $<9$ & Good \\
\hline 350 & APARTMENT 4 & Yes & Yes & Yes & Low & Moderate & Yes & $30-70$ & $<9$ & Good \\
\hline 351 & APARTMENT 6 & Yes & Yes & Yes & Low & Moderate & Yes & $30-70$ & $<9$ & Good \\
\hline 359 & APARTMENT 5 & Yes & Yes & Yes & Low & Moderate & Yes & $30-70$ & $<9$ & Good \\
\hline 360 & APARTMENT 3 & Yes & Yes & Yes & Low & Moderate & Yes & $30-70$ & $<9$ & Good \\
\hline 361 & APARTMENT 1 & Yes & Yes & Yes & Low & Moderate & Yes & $30-70$ & $<9$ & Good \\
\hline 362 & APARTMENT 22 & Yes & Yes & Yes & Low & Moderate & Yes & $30-70$ & $<9$ & Good \\
\hline 363 & COIN LAUNDRY & Yes & Yes & Yes & Low & Moderate & Yes & $30-70$ & $<9$ & Good \\
\hline 364 & APARTMENT 40 & Yes & Yes & Yes & Low & Low & Yes & $30-70$ & $<9$ & Good \\
\hline 365 & APARTMENT 41 & Yes & Yes & Yes & Low & Low & Yes & $30-70$ & $<9$ & Good \\
\hline 366 & APARTMENT 42 & Yes & Yes & Yes & Low & Low & Yes & $30-70$ & $<9$ & Good \\
\hline 367 & APARTMENT 43 & Yes & Yes & Yes & Low & Low & Yes & $30-70$ & $<9$ & Good \\
\hline
\end{tabular}




\begin{tabular}{|c|c|c|c|c|c|c|c|c|c|c|}
\hline 0368-01 & |SUMMER COTTAGE & No & No & No & Low & High & No & $<30$ & $<9$ & Good \\
\hline $0368-02$ & SUMMER COTTAGE & No & No & No & Low & High & No & $<30$ & $<9$ & Good \\
\hline $0368-03$ & SUMMER COTTAGE & No & No & No & Low & High & No & $<30$ & $<9$ & Good \\
\hline $0368-04$ & SUMMER COTTAGE & No & No & No & Low & High & No & $<30$ & $<9$ & Good \\
\hline $0368-05$ & SUMMER COTTAGE & No & No & No & Low & High & $\mathrm{No}$ & $<30$ & $<9$ & Good \\
\hline $0368-06$ & SUMMER COTTAGE & No & No & No & Low & High & No & $<30$ & $<9$ & Good \\
\hline 0368-07 & SUMMER COTTAGE & No & No & No & Low & High & No & $<30$ & $<9$ & Good \\
\hline $0368-08$ & SUMMER COTTAGE & No & No & No & Low & High & No & $<30$ & $<9$ & Good \\
\hline $0368-09$ & SUMMER COTTAGE & No & No & No & Low & High & No & $<30$ & $<9$ & Good \\
\hline $0368-10$ & SUMMER COTTAGE & No & No & No & Low & High & No & $<30$ & $<9$ & Good \\
\hline $0368-11$ & SUMMER COTTAGE & No & No & No & Low & High & No & $<30$ & $<9$ & Good \\
\hline $0368-12$ & SUMMER COTTAGE & No & No & No & Low & High & No & $<30$ & $<9$ & Good \\
\hline $0368-13$ & SUMMER COTTAGE & No & No & No & Low & High & No & $<30$ & $<9$ & Good \\
\hline $0368-14$ & SUMMER COTTAGE & No & No & No & Low & High & No & $<30$ & $<9$ & Good \\
\hline $0368-15$ & SUMMER COTTAGE & No & No & No & Low & High & No & $<30$ & $<9$ & Good \\
\hline $0368-16$ & SUMMER COTTAGE & No & No & No & Low & High & No & $<30$ & $<9$ & Good \\
\hline $0368-17$ & SUMMER COTTAGE & No & No & No & Low & High & No & $<30$ & $<9$ & Good \\
\hline $0368-18$ & SUMMER COTTAGE & No & No & No & Low & High & No & $<30$ & $<9$ & Good \\
\hline $0368-19$ & SUMMER COTTAGE & No & No & No & Low & High & No & $<30$ & $<9$ & Good \\
\hline $0368-20$ & SUMMER COTTAGE & No & No & No & Low & High & No & $<30$ & $<9$ & Good \\
\hline $0368-21$ & SUMMER COTTAGE & No & No & No & Low & High & No & $<30$ & $<9$ & Good \\
\hline $0368-22$ & SUMMER COTTAGE & No & No & No & Low & High & No & $<30$ & $<9$ & Good \\
\hline $0368-23$ & SUMMER COTTAGE & No & No & No & Low & High & No & $<30$ & $<9$ & Good \\
\hline $0368-24$ & SUMMER COTTAGE & No & No & No & Low & High & No & $<30$ & $<9$ & Good \\
\hline $0368-25$ & SUMMER COTTAGE & No & No & No & Low & High & No & $<30$ & $<9$ & Good \\
\hline $0368-26$ & SUMMER COTTAGE & No & No & No & Low & High & No & $<30$ & $<9$ & Good \\
\hline $0368-27$ & SUMMER COTTAGE & No & No & No & Low & High & No & $<30$ & $<9$ & Good \\
\hline $0368-28$ & SUMMER COTTAGE & No & No & No & Low & High & No & $<30$ & $<9$ & Good \\
\hline $0368-29$ & SUMMER COTTAGE & No & No & No & Low & High & No & $<30$ & $<9$ & Good \\
\hline $0368-30$ & SUMMER COTTAGE & No & No & No & Low & High & No & $<30$ & $<9$ & Good \\
\hline $0369-09$ & MOBILE HOME & No & No & No & Low & High & No & $<30$ & $<9$ & Good \\
\hline $0369-10$ & MOBILE HOME & No & No & No & Low & High & No & $<30$ & $<9$ & Good \\
\hline $0369-11$ & MOBILE HOME & No & No & No & Low & High & No & $<30$ & $<9$ & Good \\
\hline $0369-12$ & MOBILE HOME & No & No & No & Low & High & No & $<30$ & $<9$ & Good \\
\hline $0369-13$ & MOBILE HOME & No & No & No & Low & High & No & $<30$ & $<9$ & Good \\
\hline $0369-14$ & MOBILE HOME & No & No & No & Low & High & No & $<30$ & $<9$ & Good \\
\hline $0369-15$ & MOBILE HOME & No & No & No & Low & High & No & $<30$ & $<9$ & Good \\
\hline $0369-16$ & MOBILE HOME & No & No & No & Low & High & No & $<30$ & $<9$ & Good \\
\hline
\end{tabular}




\begin{tabular}{|c|c|c|c|c|c|c|c|c|c|c|}
\hline 373 & CHILD CARE FACILITY & Yes & No & Yes & Low & Low & No & $30-70$ & $<9$ & Good \\
\hline 405 & BUILDING STORAGE & Yes & Yes & No & Low & Low & No & $<30$ & $<9$ & Good \\
\hline 422 & CABINET/SIGN SHOP & Yes & Yes & No & Low & Low & No & $30-70$ & $<9$ & Good \\
\hline 475 & REACTOR SAFETY & Yes & Yes & No & Low & Low & No & $<30$ & $<9$ & Good \\
\hline 479 & MACHINE SHOP B & Yes & Yes & No & Low & Low & No & $>100$ & $<9$ & Good \\
\hline 488 & BERKNER HALL & Yes & No & No & Low & Low & No & $<30$ & $<9$ & Good \\
\hline 493 & VIDEO WORKS AREA & Yes & Yes & No & Low & Low & No & $30-70$ & $<9$ & Good \\
\hline 494 & $\begin{array}{l}\text { BNL RECORDS } \\
\text { HOLDING }\end{array}$ & Yes & Yes & No & Low & Low & No & $30-70$ & $<9$ & Good \\
\hline 495 & $\begin{array}{l}\text { OIL DRUM STORAGE } \\
\text { FACILITY }\end{array}$ & Yes & Yes & Yes & Low & Low & No & $30-70$ & $<9$ & Good \\
\hline 498 & \begin{tabular}{|l} 
CENTRAL \\
DEGREASER
\end{tabular} & Yes & Yes & No & Low & Low & No & $30-70$ & $<9$ & Good \\
\hline 526 & $\begin{array}{l}\text { ENERGY/LABS/STOR/C } \\
\text { ON }\end{array}$ & Yes & Yes & No & Low & Low & No & $30-70$ & $<9$ & Good \\
\hline 527 & $\begin{array}{l}\text { COMBUSTION } \\
\text { RESEARCH }\end{array}$ & Yes & Yes & No & Low & Low & No & $>100$ & $<9$ & Good \\
\hline 528 & REACTOR SYSTEMS & Yes & Yes & No & Low & Low & No & $<30$ & $<9$ & Good \\
\hline 590 & $\begin{array}{l}\text { ENVMNTL MONTG } \\
\text { STATION - P2 }\end{array}$ & Yes & Yes & No & Low & Low & No & $<30$ & $<9$ & Good \\
\hline 591 & $\begin{array}{l}\text { ENVMNTL MONTG } \\
\text { STATION - P9 }\end{array}$ & Yes & Yes & No & Low & Low & No & $<30$ & $<9$ & Good \\
\hline 592 & $\begin{array}{l}\text { ENVMNTL MONTG } \\
\text { STATION - S5 }\end{array}$ & Yes & Yes & No & Low & Low & No & $<30$ & $<9$ & Good \\
\hline 593 & $\begin{array}{l}\text { ENVMNTL MONTG } \\
\text { STATION - S6 }\end{array}$ & Yes & Yes & No & Low & Low & No & $<30$ & $<9$ & Good \\
\hline 0593A & $\begin{array}{l}\text { ENVMNTL MONTG } \\
\text { STATION }\end{array}$ & Yes & Yes & No & Low & Low & No & $<30$ & $<9$ & Good \\
\hline 594 & $\begin{array}{l}\text { ENVMNTL MONTG } \\
\text { STATION - P7 }\end{array}$ & Yes & Yes & No & Low & Low & No & $<30$ & $<9$ & Good \\
\hline 595 & $\begin{array}{l}\text { ENVMNTL MONTG } \\
\text { STATION - HMNo }\end{array}$ & Yes & Yes & No & Low & Low & No & $<30$ & $<9$ & Good \\
\hline 596 & $\begin{array}{l}\text { ENVMNTL MONTG } \\
\text { STATION - HMs }\end{array}$ & Yes & Yes & No & Low & Low & No & $<30$ & $<9$ & Good \\
\hline 597 & $\begin{array}{l}\text { ENVMNTL MONTG } \\
\text { STATION - HQ }\end{array}$ & Yes & Yes & No & Low & Low & No & $<30$ & $<9$ & Good \\
\hline 598 & $\begin{array}{l}\text { GROUNDWATER } \\
\text { TREATMENT }\end{array}$ & & & & Low & Low & Yes & $>100$ & $<9$ & Good \\
\hline 599 & FIRE HOUSE & No & Yes & No & Low & Low & Yes & $30-70$ & $<9$ & Good \\
\hline
\end{tabular}




\begin{tabular}{|c|c|c|c|c|c|c|c|c|c|c|}
\hline 624 & $\begin{array}{l}\text { WATER TREATMT } \\
\text { PLANT }\end{array}$ & No & Yes & No & Low & Low & Yes & $30-70$ & $21-30$ & Good \\
\hline 642 & $\begin{array}{l}\text { EQUIP STOR WATER } \\
\text { TRT }\end{array}$ & Yes & Yes & No & Low & Low & No & $30-70$ & $<9$ & Good \\
\hline 835 & RHIC CRYO & Yes & Yes & No & Low & Low & No & $30-70$ & $<9$ & Good \\
\hline 915 & AGS WELL 101 & No & Yes & No & Low & Low & No & $<30$ & $<9$ & Good \\
\hline 916 & AGS WELL 102 & No & Yes & No & Low & Low & No & $<30$ & $<9$ & Good \\
\hline 917 & AGS WELL 103 & No & Yes & No & Low & Low & No & $<30$ & $<9$ & Good \\
\hline 926 & $\begin{array}{l}\text { RECEIVING/WAREHOU } \\
\text { SE }\end{array}$ & Yes & Yes & No & Low & Low & Yes & $<30$ & $<9$ & Good \\
\hline 930 & 200 MEV LINAC & Yes & No & No & Low & Low & No & $<30$ & $>41$ & Good \\
\hline 935 & $\begin{array}{l}\text { BNL SCIENCE } \\
\text { MUSEIUM }\end{array}$ & Yes & Yes & No & Low & Low & No & $30-70$ & $<9$ & Good \\
\hline 936 & EQUIPMENT STORAGE & Yes & Yes & No & Low & Low & No & $<30$ & $<9$ & Good \\
\hline 959 & $\begin{array}{l}\text { ENVMNTL MONTG } \\
\text { STATION - HTe }\end{array}$ & Yes & Yes & No & Low & Low & No & $<30$ & $<9$ & Good \\
\hline 1002 & $\begin{array}{l}\text { BRAHMNS } \\
\text { EXPERIMENTAL HALL }\end{array}$ & Yes & Yes & No & Low & Low & No & $<30$ & $21-30$ & Good \\
\hline $1002 A$ & \begin{tabular}{|l|} 
INSTRUMENTATION / \\
BRAHMNS SER
\end{tabular} & Yes & Yes & No & Low & Low & No & $<30$ & $21-30$ & Good \\
\hline 1002B & $\begin{array}{l}\text { 2:00 CRYO SERVICE } \\
\text { BUILDING }\end{array}$ & Yes & Yes & No & Low & Low & No & $<30$ & $21-30$ & Good \\
\hline $1002 C$ & $\begin{array}{l}\text { FAST ELECTRONIC } \\
\text { HUT }\end{array}$ & Yes & Yes & No & Low & Low & No & $<30$ & $21-30$ & Good \\
\hline 1002D & $\begin{array}{l}\text { BRAHMS COUNTING } \\
\text { HOUSE }\end{array}$ & Yes & Yes & No & Low & Low & No & $<30$ & $21-30$ & Good \\
\hline 1008B & $\begin{array}{l}\text { 8:00 CRYO / PHENIX } \\
\text { MAGNET SER }\end{array}$ & Yes & Yes & No & Low & Low & No & $30-70$ & $<9$ & Good \\
\hline $1008 \mathrm{C}$ & CHILLER FACILITY & Yes & Yes & No & Low & Low & $\mathrm{No}$ & $30-70$ & $<9$ & Good \\
\hline 1101 & ASSEMBLY BUILDING & Yes & Yes & No & Low & Low & No & $30-70$ & $<9$ & Good \\
\hline
\end{tabular}

General Note

\section{Definations}

Building Number

Building Name

Ingress/Egress

Identification of Buildings

Building Fire Resistance

Roof Combustiblity

Siding and Deck Combustiblity

Slope

Availabilty of Fire fighting water
This table is based on elements and risk factors described in NFPA 299, Table A-3-2(a) Wildfire Hazard Severity Form Checklist

Orange boxes indicate conditions warranting corrective action.

Offical number assigned by Plant Engineering

Offical name assigned by Plant Engineering

Factors effecting escape of building occupants as well as simultanous access by fire department equipment

Adequate signage to identify a facility to fire department units, which may include Non BNL Fire Departments on site to assist in suppression

One of two main facotrs effecting the risk to a facitly from an external fire

Low $=$ Underwriter's Laborotry Class A roof covering (Best), Medium $=$ UL Class B roof, Low $=$ Noncombustible siding/deck (cinder block, abestos), Medium = low combustible material (vinyl siding on wood), High = Combustible (bare wood)

Second of two major factors effecting the risk to a facility from an external fire, measured Good $=500 \mathrm{gpm}$ minimum water source availability with $1000 \mathrm{ft}$. from pressurized hydrants, Fair = Sources within 20 min round-trip (hydrants or draft sources), Poor = Sources within 21-45 min round-trip (hydrants or draft sources) 